Environmental Restoration Division Clinch River Environmental Restoration Program

\title{
Transport and Accumulation of Cesium-137 and Mercury in the Clinch River and Watts Bar Reservoir System
}

\author{
C. R. Olsen, I. L Larsen, P. D. Lowry, C. R. Moriones, \\ C. J. Ford, K. C. Dearstone, R. R. Turner, \\ B. L. Kimmel, C. C. Brandt
}

Date Issued-June 1992

\author{
Prepared by \\ Environmental Sciences Division \\ Oak Ridge National Laboratory \\ ESD Publication 3471 \\ Prepared for \\ U.S. Department of Energy
}

Office of Environmental Restoration and Waste Management

under budget and reporting codes CD 1072 and EW 20

OAK RIDGE NATIONAL LABORATORY

Oak Ridge, Tennersee 37831-6285

managed by

MARTIN MARIETTA ENERGY SYSTEMS, INC.

for the

U.S. DEPARTMENT OF ENERGY

under contract DE-ACO5-84OR21400

DISTRIBUTION OF THIS DOCUMENT IS UNLIMITED 


\begin{abstract}
Author Affiliations
C. R. Olsen, I. L. Larsen, C. J. Ford, K. C. Dearstone, R. R. Turner, and B. L. Kimmel are members of the Environmental Sciences Division, Oak Ridge National Laboratory, Martin Marietta Energy Systems, Inc. C. C. Brandt is a member of the Engineering Physies and Mathematics Division, Oak Ridge National Laboratory, Martin Marietta Energy Systems, Inc. P. D. Lowry is affiliated with the Department of Anesthesiology, Emory University School of Medicine, Atlanta, Georgia. C. R. Moriones is a member of the Health Physics Research Division, Philippine Atomic Energy Commission, Diliman, Quezon City, Philippines.
\end{abstract}

\title{
Note to Recipients of ORNL/ER-7
}

The draft version of this report was distributed for comments in March 1990. Only minor changes were made for this final version. 


\section{CONTENTS}

FIGURES $\ldots \ldots \ldots \ldots \ldots \ldots \ldots \ldots \ldots \ldots \ldots \ldots \ldots \ldots \ldots \ldots$

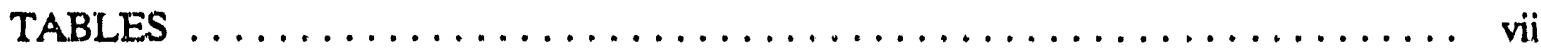

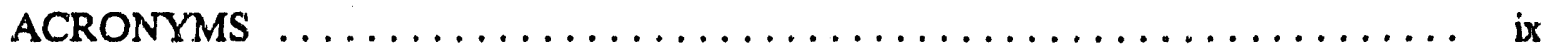

ACKNOWLEDGMENTS $\ldots \ldots \ldots \ldots \ldots \ldots \ldots \ldots \ldots \ldots \ldots \ldots \ldots \ldots \ldots$

EXECUTTVE SUMMARY $\ldots \ldots \ldots \ldots \ldots \ldots \ldots \ldots \ldots \ldots \ldots \ldots \ldots \ldots \ldots$

INTRODUCTION $\ldots \ldots \ldots \ldots \ldots \ldots \ldots \ldots \ldots \ldots \ldots \ldots \ldots \ldots \ldots$

HISTORY OF CONTAMINANT RELEASES $\ldots \ldots \ldots \ldots \ldots \ldots \ldots \ldots$

PREVIOUS STUDIES $\ldots \ldots \ldots \ldots \ldots \ldots \ldots \ldots \ldots \ldots \ldots \ldots \ldots$

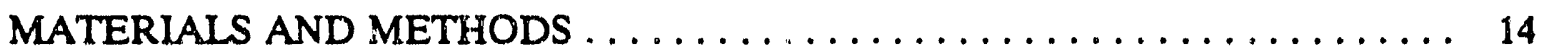

SEDIMENT ANALYSES $\ldots \ldots \ldots \ldots \ldots \ldots \ldots \ldots \ldots \ldots \ldots \ldots \ldots \ldots$

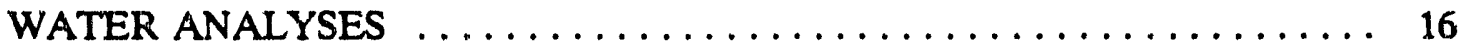

RESULTS AND DISCUSSION $\ldots \ldots \ldots \ldots \ldots \ldots \ldots \ldots \ldots \ldots \ldots \ldots$

CONTAMINANTS IN THE WATER COLUMN $\ldots \ldots \ldots \ldots \ldots \ldots \ldots \ldots . \ldots \ldots$

CONTAMINANTS IN BOTTOM SEDIMENTS $\ldots \ldots \ldots \ldots \ldots \ldots \ldots \ldots . \ldots$

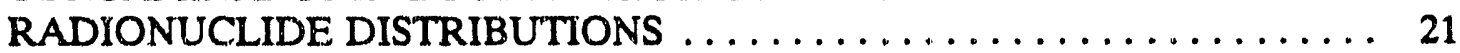

MERCURY AND ${ }^{137} \mathrm{CS}$ CORRELATIONS ................ 28

HISTORICAL CONCENTRATIONS OF DISSOLVED MERCURY

IN WATTS BAR RESERVOIR $\ldots \ldots \ldots \ldots \ldots \ldots \ldots \ldots \ldots \ldots \ldots$

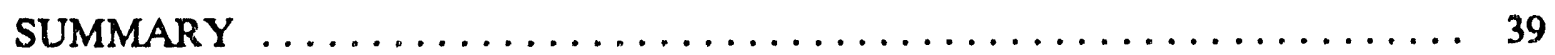

REFERENCES $\ldots \ldots \ldots \ldots \ldots \ldots \ldots \ldots \ldots \ldots \ldots \ldots \ldots \ldots \ldots \ldots \ldots \ldots$

Appendix A: RADIONUCLIDE CONCENTRATIONS IN WATTS BAR

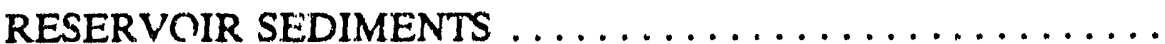

\section{DISCLAIMER}

This report was prepared as an account of work sponsored by an agency of the United States Government. Neither the United States Gnvernment nor any agency thereof, nor any of their employees, makes any warranty, express or implied, or assumes any legal liability or responsibilit, ior the accuracy, completeness, or usefulness of any information, apparatus, product, or process disclosed, or represents that its use would not infringe privately owned rights. Reference herein to any specific cornmercial product, process, or service by trade name, trademark. manufacturer, or otherwise does not necessarily constitute or imply its endorsement, recommendation, or favoring by the United States Government or any agency thereof. The views and opinions of authors expressed herein do not necessarily state or teflest those of the Unitod States Government or any agency thereof. 


\section{FIGURES}

1 Map showing the Clinch River and Tennessee River tributaries to Watts Bar Reservoir and the location of the three DOE facilities on the ORR ....... 2

2 Aquatic discharge histories for $\mathrm{Hg}$ from the Y-12 Plant and for ${ }^{137} \mathrm{Cs}$ from ORNL 3

3 Vertical distribution of ${ }^{137} \mathrm{Cs}$, mercury, ${ }^{238} \mathrm{U}$, and several other contaminants in a sediment core collected at the junction of East Fork Poplar Creek and Poplar Creek, a sediment core collected in Poplar Creek just downstream of the K-25 Site, and a sediment core collected near the mouth of the Clinch River at Kingston ...

4 Vertical profiles of ${ }^{137} \mathrm{Cs}$ and $\mathrm{Hg}$ for selected sediment cores collected in the Tennessee River Reservoir system.

5 Map of Watts Bar Reservoir indicating the locations and identifying the sediment cores collected in this study $\ldots \ldots \ldots \ldots \ldots \ldots \ldots \ldots \ldots \ldots \ldots$

6 Map of Watts Bar Reservoir indicating the locations of the surface grab samples

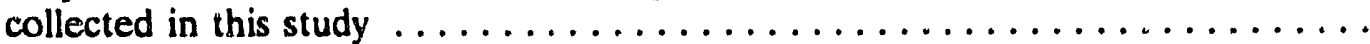

7 Map of the surface sedimentary characteristics based on the visual textural analysis of more than 190 surface sediment samples collected in Watts Bar Reservoir. . . .

8 Map of Watts Bar Reservoir illustrating the average ${ }^{137} \mathrm{Cs}$ concentration ( $\mathrm{pCi} / \mathrm{g}$ ) in

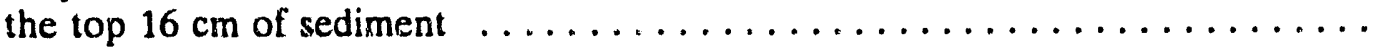

9 Vertical distribution of ${ }^{137} \mathrm{Cs}$ with sediment depth in cores $\mathrm{KCP}, 567.5,5-4-5,6-2-1$,

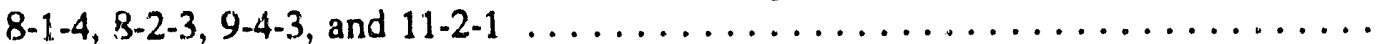

10 Vertical profiles for ${ }^{137} \mathrm{Cs},{ }^{60} \mathrm{Co}$, and excess ${ }^{210} \mathrm{~Pb}$ in sediment core $567.5 \ldots \ldots$ 24

11 Vertical distribution of ${ }^{90} \mathrm{~S} r$ in sediment core $567.5 \ldots \ldots \ldots \ldots \ldots$

12 Vertical profiles for ${ }^{137} \mathrm{Cs}$ and excess ${ }^{210} \mathrm{~Pb}$ in the sediments of Norris Reservoir . 25

13 Map of Watts Bar Reservoir illustrating the GIS polygonal areas that were used for integrating the sediment core data over the entire reservoir $\ldots \ldots \ldots \ldots \ldots$

14 Map of Watts Bar Reservoir illustrating ${ }^{137} \mathrm{Cs}$ accumulation patterns and total

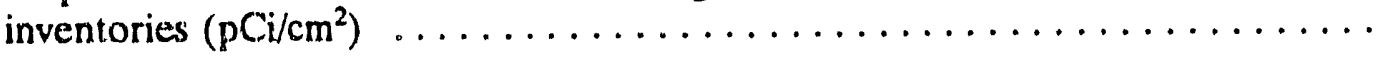

15 Map of Watts Bar Reservoir illustrating the inventory $\left(\mathrm{pCi} / \mathrm{cm}^{2}\right)$ of ${ }^{137} \mathrm{Cs}$ in the top

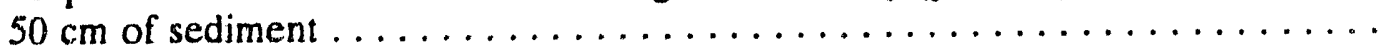


16 Map of Watts Bar Reservoir illustrating the inventory $\left(\mathrm{pCi} / \mathrm{cm}^{2}\right)$ of ${ }^{137} \mathrm{Cs}$ in the top

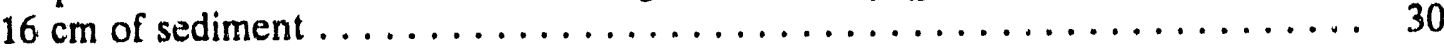

17 The history of ${ }^{137} \mathrm{Cs}$ releases from ORNL and $\mathrm{Hg}$ releases from $\mathrm{Y}-12$ compared with the vertical distribution of ${ }^{137} \mathrm{Cs}$ and $\mathrm{Hg}$ in the sediments of core KCP ...... 31

18 Illustration of the relationship between the concentration of ${ }^{137} \mathrm{Cs}$ and the concentration of $\mathrm{Hg}$ in the sediments of Wats Bar Reservoir ...........

19 Map of Watts Bar Reservoir illustrating $\mathrm{Hg}$ accumulation patterns and total

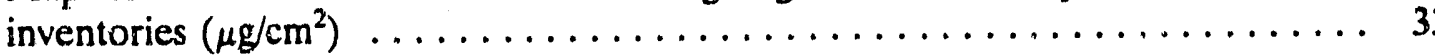

20 Map of Watts Bar Reservoir illustrating the $\mathrm{Hg}$ inventory $\left(\mu \mathrm{g} / \mathrm{cm}^{2}\right)$ in the upper

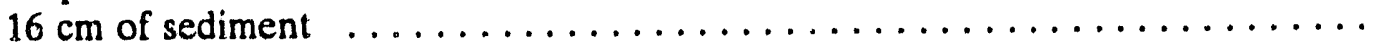

21 Map of Watts Bar Reservoir illustrating the average $\mathrm{Hg}$ concentration $(\mu \mathrm{g} / \mathrm{g})$ in

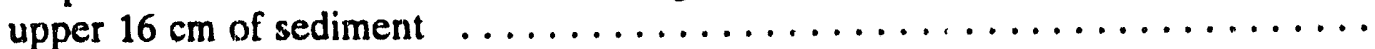




\section{TABLES}

1 Annual discharges (Ci) of radionuclides from White Oak Lake to the Clinch River, 1944 to $1984 \ldots \ldots \ldots \ldots \ldots \ldots \ldots \ldots \ldots \ldots \ldots \ldots \ldots \ldots \ldots$

2 Vertical distribution of mercury, ${ }^{137} \mathrm{Cs}$, and ${ }^{238} \mathrm{U}$ in a Poplar Creek sediment core collected near Blair Road Bridge $\ldots \ldots \ldots \ldots \ldots \ldots \ldots \ldots \ldots \ldots$

3 EPA EMSL-LV Intercomparison Study, April 1987, Marinelli beaker geometry . 15

4 National Bureau of Standards SRM 4353 Rocky Flats soil, aluminum can

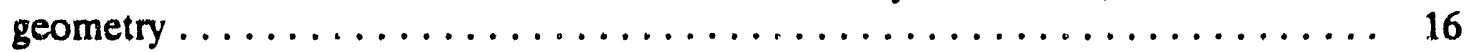

5 Contaminant distributions between aqueous and particulate phases ........ 19

6 Watts Bar sediment core $567.5 \ldots \ldots \ldots \ldots \ldots \ldots \ldots \ldots \ldots \ldots \ldots$

7 Watts Bar sediment core $8-2-3 \ldots \ldots \ldots \ldots \ldots \ldots \ldots \ldots \ldots \ldots$ 


\section{ACRONYMS}

$\begin{array}{ll}\text { ACD } & \text { Analytical Chemistry Division } \\ \text { CERCLA } & \text { Comprehensive Environmental Response, Compensation, and Liability Act } \\ \text { DOE } & \text { Department of Energy } \\ \text { EFPC } & \text { East Fork Poplar Creek } \\ \text { EMSL-LV } & \text { Environmental Monitoring Systems Laboratory, Las Vegas } \\ \text { EPA } & \text { Environmental Protection Agency } \\ \text { FFA } & \text { Federal Facility Agreement } \\ \text { GIS } & \text { Geographic Information System } \\ \text { Hg } & \text { mercury } \\ \text { HSWA } & \text { Hazardous and Solid Waste Amendments } \\ \text { KCP } & \text { a core taken near Kingston City Park } \\ \text { NBS } & \text { National Bureau of Standards } \\ \text { ORNL } & \text { Oak Ridge National Laboratory } \\ \text { ORR } & \text { Oak Ridge Reservation } \\ \text { ORTF } & \text { Oak Ridge Task Force } \\ \text { Pb } & \text { lead } \\ \text { PCBs } & \text { polychlorinated biphenyls } \\ \text { Pu } & \text { plutonium } \\ \text { RCRA } & \text { Resource Conservation and Recovery Act } \\ \text { SARA } & \text { Superfund Amendments and Reauthorization Act of } 1986 \\ \text { SRM } & \text { standard reference material } \\ \text { TVA } & \text { Tennessee Valley Authority } \\ \text { WOD } & \text { White Oak Dam } \\ \text { WOL } & \text { White Oak Lake }\end{array}$




\section{ACKNOWLEDGMENTS}

We would like to thank Werner Furth of Martin-Marietta Energy Systems Central Staff, Tim Myrick of the ORNL Remedial Action Program, and Todd Butz of the Y-12 Remedial Action Program for recognizing the need for initiation of this off-site scoping activity. This project was begun as a component of the ORNL Biological Monitoring and Abatement Program directed by Jim Loar.

We also thank Scott Gregory, Della Marshall, and Chris Kauker for field assistance, and Les Hook and Jean Shaakir-Ali for their help with data analysis. Tammy McKenzie, Polly Henry, Gail Epperson, and Donna Rhew provided valuable assistance in preparing various stages of the manuscript. We thank Janet Addison, Janice Asher, Lydia Corrill, and Sharon McConathy for editorial assistance, and the Environmental Sciences Division Graphics Office for producing the figures. Bob Cook and Karen Von Damm provided valuable technical reviews of the manuscript. 


\section{EXECUTIVE SUMMARY}

Operations and waste disposal activities on the U.S. Department of Energy's Oak Ridge Reservation have introduced cesium-137 $\left({ }^{137} \mathrm{Cs}\right)$ and mercury $(\mathrm{Hg})$ into local streams that ultimately drain into the Clinch River and Watts Bar Reservoir system. The highest discharges for both ${ }^{137} \mathrm{Cs}$ and $\mathrm{Hg}$ occurred during the mid-1950s. Measurements of the partitioning of ${ }^{137} \mathrm{Cs}$ and $\mathrm{Hg}$ between dissolved and varticulate phases in the reservoir water column indicate that both contaminants have particle-to-water sorption ratios of about $10^{5}$ and are therefore strongly associated with particles in this aquatic system. About 190 surface-sediment grab samples and more than 60 sediment cores were collected in Watts Bar Reservoir to (1) determine the extent of downstream contamination and (2) document particle and particleassociated contaminant accumulation patterns. The vertical distributions of ${ }^{137} \mathrm{Cs}$ and $\mathrm{Hg}$ in these sediment cores are strongly correlated $\left(r^{2}=0.87\right)$, and both contaminants exhibit a large subsurface peak coincident with their peak discharge histories. Concentrations of ${ }^{137} \mathrm{Cs}$ and $\mathrm{Hg}$ as high as $80 \mathrm{pCi} / \mathrm{g}(3.0 \mathrm{Bg} / \mathrm{g})$ and $47 \mu \mathrm{g} / \mathrm{g}$, respectively, occur in this subsurface peak. A preliminary screening of the contaminants that may contribute to human health and environmental risk (Hoffman et al. 1991; Suter $1991^{\dagger}$ ) showed that these ${ }^{137} \mathrm{Cs}$ and $\mathrm{Hg}$ concentrations do not pose an imminent risk, especially if deep sediments are not disturbed. Further study, however, is warranted to determine the need for remediation. The sediment depth of this subsurface peak and the thickness of contaminated sediment varies with location in the reservoir and depends on the rate of sediment accumulation. The total accumulation of ${ }^{137} \mathrm{Cs}$ in Watts Bar Reservoir sediments has been estimated by measuring the ${ }^{137} \mathrm{Cs}$ inventory in each sediment core and extrapolating these data spatially with the ARC:INFO Geographic Information Systern software package. Results indicate that about $304 \mathrm{Ci}(1.12$ $\times 10^{13} \mathrm{~Bq}$ ) of ${ }^{137} \mathrm{Cs}$ now reside in the reservoir sediments. Discharge records indicate that a decay-corrected total of about $335 \mathrm{Ci}\left(1.24 \times 10^{13} \mathrm{~Bq}\right)$ of ${ }^{137} \mathrm{Cs}$ have been released into the river system between 1949 and 1986. Some ${ }^{137} \mathrm{Cs}$ was released before 1949 , but discharges prior to 1949 were not monitored for ${ }^{137} \mathrm{Cs}$. Sediment core profiles of ${ }^{137} \mathrm{Cs}$ in the Clinch River and Watts Bar Reservoir suggest that the annual arnounts discharged from White Oak Dam before 1949 were considerably less than the amount discharged in 1949. The comparison between measured and discharged ${ }^{137} \mathrm{Cs}$ indicates that almost $91 \%$ of the total ${ }^{137} \mathrm{Cs}$ released to the Clinch River and Tennessee River system has been retained by accumulation in Watts Bar Reservoir sediments. Using the strong correlation between the vertical distribution of ${ }^{137} \mathrm{Cs}$ and $\mathrm{Hg}$ in sediment cores, it has been estimated that about 76 metric tons of $\mathrm{Yig}$ have also accumulated in the sediments of Watts Bar Reservoir. The vertical distribution of ${ }^{137} \mathrm{Cs}$ and $\mathrm{Hg}$ in dated sediment cores was also used to document levels of contamination in the reservoir water column during the past 40 years.

F. O. Hoffman, B. G. Blaylock, M. L. Frank, L. A. Hook, E. L. Etnier, and S. S. Talmage. 1991. Preliminary Screening of Contaminants in the Off-Site Surface Water Environment Downstream of the U.S. Department of Energy Oak Ridge Reservation. ORNL/ER-9. Martin Marietta Energy Systems, Inc., Oak Ridge National Laboratory, Oak Ridge, Tenn.

'G. W. Suter II. May 1991. Screening Level Risk Assessment for Off. Site Ecological Effects in Surface Waters Downstream from the U.S. Department of Energy Oak Ridge Reservation. ORNLER-8. Martin Marietta Energy Systems, Inc., Oak Ridge National Laboratory, Oak Ridge, Tenn. 


\section{INTRODUCTION}

Operations and waste disposal activities at the Oak Ridge Y-12 Plant, the Oak Ridge National Laboratory (ORNL), and the Oak Ridge K-25 Site (formerly the Oak Ridge Gaseous Diffusion Plant) on the U.S. Department of Energy (DOE) Oak Ridge Reservation (ORR) have introduced a variety of airborne, liquid, and solid wastes into the surrounding environment. Some of these wastes may affect off-site areas by entering local streams, which ultimately drain into the Clinch and Tennessee river system (Fig. 1). Previously reported concentrations of radionuclides, metals, and organic compounds in water, sediment, and biota of the Clinch River and Watts Bar Reservoir suggest the presence of a variety of contaminants of possible concern to the protection of human health and the environment.

DOE has initiated a comprehensive waste management and environmental restoration effort to achieve the comprehensive remediation of releases of hazardous substances, pollutants, or contaminants from the Oak Ridge Reservation (Jones et al. 1990). This effort has been undertaken in accordance with a draft Federal Facility Agreement (FFA' between the Environmental Protection Agency (EPA) Region IV, the Tennessee Department of Environment and Conservation, and DOE. The FFA requires that the cleanup of the ORR and environs be conducted in compliance with both the Resource Conservation and Recovery Act of 1976 (RCRA), as amended by the Hazardous and Solid Waste Amendments of 1984 (HWSA), and the Comprehensive Environmental Response, Compensation and Liability Act (CERCLA) of 1980, as amended by the Superfund Amendments and Reauthorization Act of 1986 (SARA).

The work reported here represents part of the initial scoping phase for the Clinch River RCRA Facility Investigation. In this work, the distribution of ${ }^{137} \mathrm{Cs}$ is used to identify contaminant accumulation patterns and potential problem, or "hot-spot," areas with regard to environmental hazard or human health. Radiocesium was chosen for this scoping effort because (1) its history of release into the Clinch River is reasonably well documented, (2) it is easy and inexpensive to measure by gamma spectrometry, and (3) it is rapidly sorbed to particulate matter and thus serves as a cost-effective tracer for identifying the transport and accumulation patterns of many other particle-reactive contaminants, such as mercury $(\mathrm{Hg})$, lead $(\mathrm{Pb})$, plutonium $(\mathrm{Pu})$, and polychlorinated biphenyls (PCBs) (Olsen et al. 1989a).

\section{HISTORY OF CONTAMINANT RELEASES}

During the mid-1950s and early 1960 s, relatively large quantities of ${ }^{137} \mathrm{Cs}$ and $\mathrm{Hg}$ were released into the Clinch River in association with nurlear energy research at ORNL and weapons components production at the Y-12 Plant, respectively (Fig. 2). Some of the ${ }^{137} \mathrm{Cs}$ and other radioactive wastes generated at ORNL enter surface streams that drain into White Oak Lake (WOL) (Fig. 1). Discharges from WOL into the Clinch River are controlled and monitored at White Oak Dam (WOD). Annual discharges of radioactivity from ORNL via WOD are summarized in Table 1 . These discharges were calculated by (1) analyzing radionuclide concentrations in weekly flow-proportional samples, (2) multiplying this concentration by the total weekly flow, and (3) integrating these weekly samples for a year. Approximately $665 \mathrm{Ci}\left(2.5 \times 10^{13} \mathrm{~Bq}\right)$ of ${ }^{137} \mathrm{Cs}$ was released from WOL into the Clinch River and Watts Bar Reservoir system between 1949 and 1986 . Some ${ }^{137} \mathrm{Cs}$ was released into the 


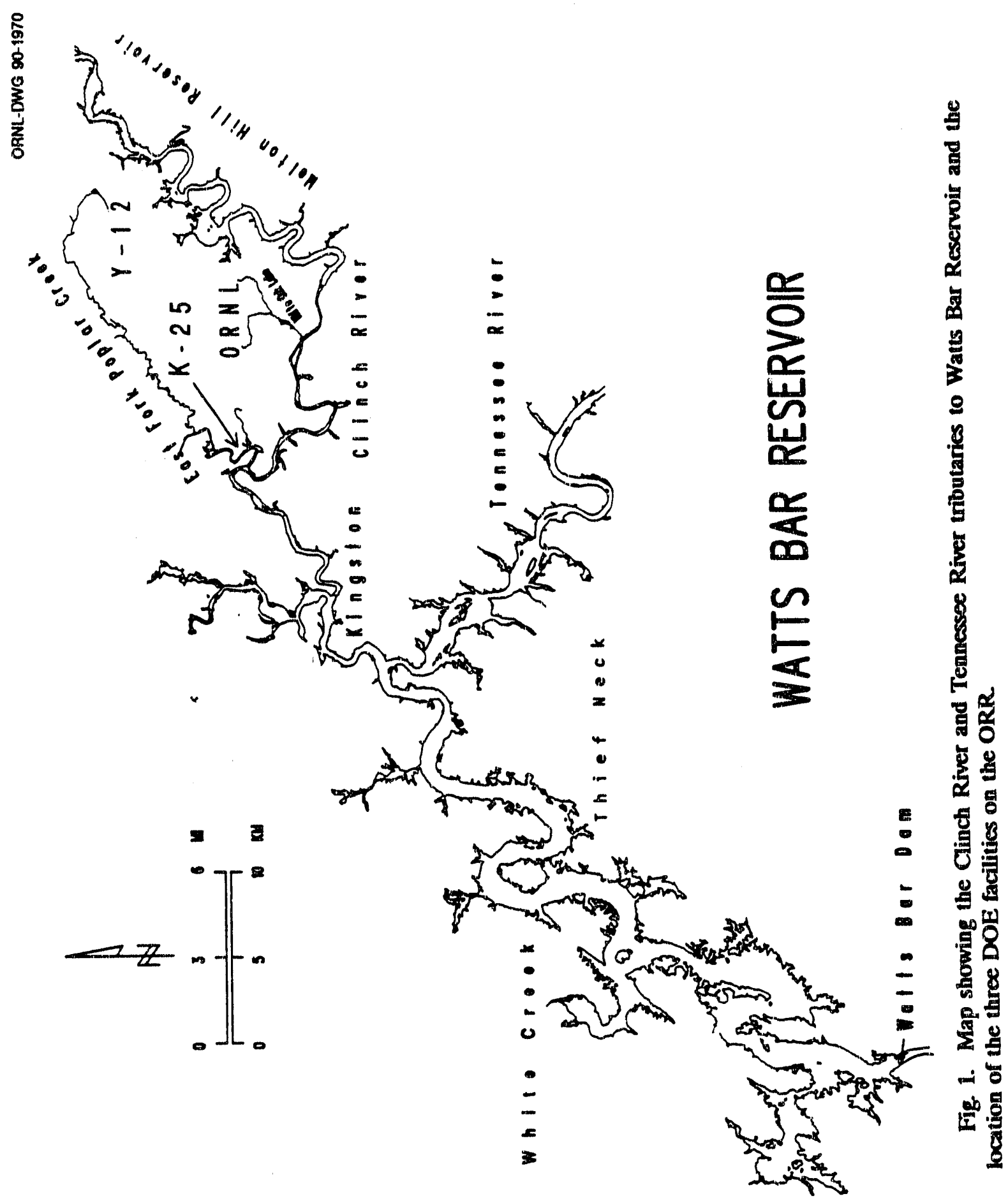




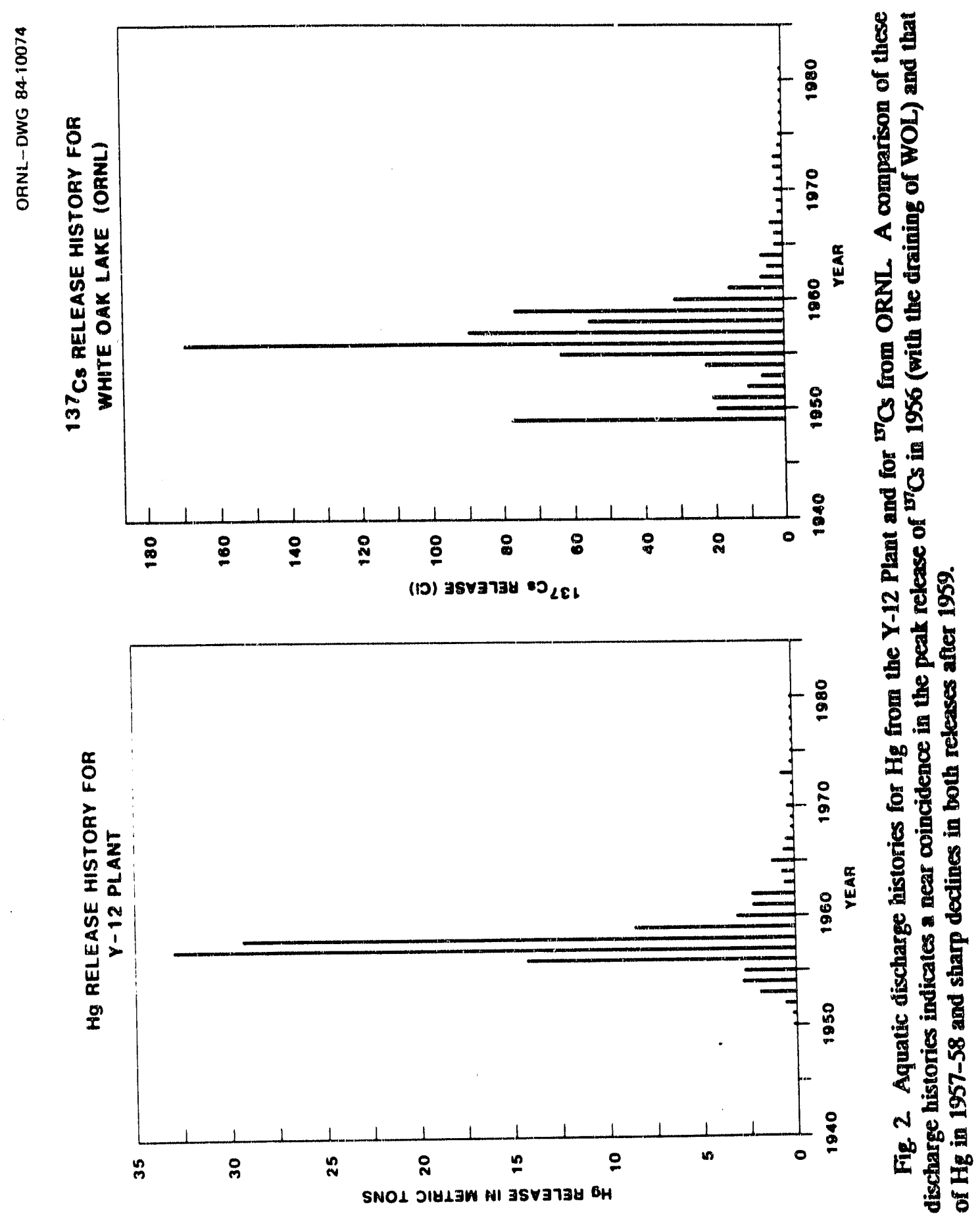




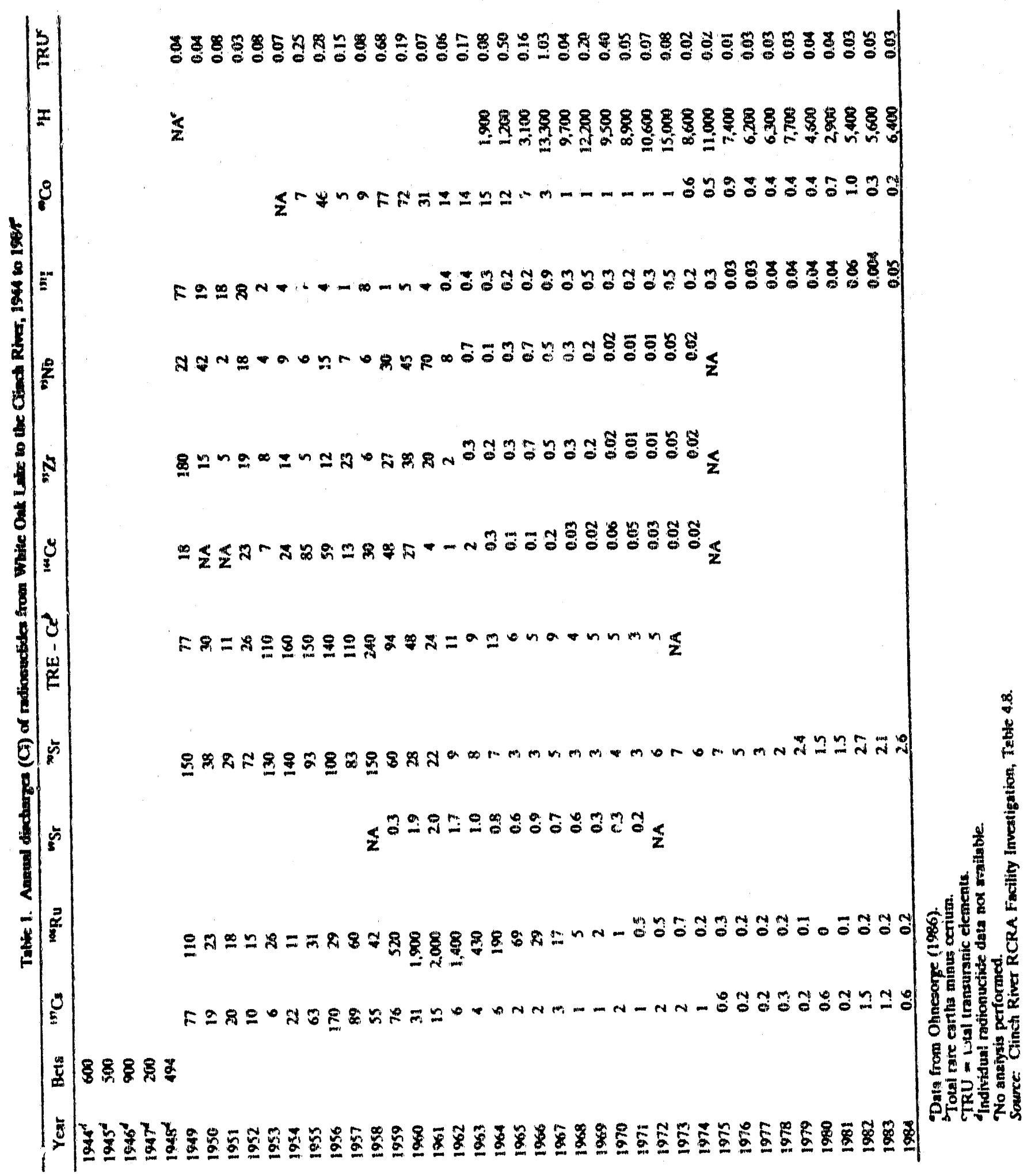


Clinch River before 1949, but discharges from WOL prior to 1949 were not monitored for ${ }^{137} \mathrm{Cs}$. Sediment core profiles of ${ }^{137} \mathrm{Cs}$ in the Clinch River and Watts Far Reservoir (see below) suggest that the annual amounts of ${ }^{137} \mathrm{Cs}$ discharged from WOD before 1949 were considerably less than the ar. sunt discharged in 1949. Because most of this release occurred in the mid-1950s in association with the draining of WOL in 1956 (Fig. 2) and because the half-life of ${ }^{137} \mathrm{Cs}$ is 30 years, the total decay-corrected amount of ${ }^{137} \mathrm{Cs}$ dir harged as of June 1986 was about $335 \mathrm{Ci}\left(1.24 \times 10^{13} \mathrm{~Bq}\right)$.

Although the history of radionuclide releases from each of the three DOE facilities on the ORR is reasonably well documented (Table 1 in DOE 1988), quantitative information on releases of most other contaminarts is either absent or incomplete. During the $1950 \mathrm{~s}$ and early $1960 \mathrm{~s}$, relatively large quantities of metallic $\mathrm{Hg}$ were released to surface waters (Fig "2) in association with the production-scale lithium-isotope separation process initiated at the Y.12 Plant in 1953. In this process, lithium isotopes are separated as they are transferred between two chemical phases. One of the e phases is a solution of lithium in $\mathrm{Hg}$, and, as a result, millions of kilograms of inorganic $\mathrm{Hg}$ were used in this separation project. Floor drains were installed in the process building to collect spilled $\mathrm{Hg}_{\mathrm{g}}$ into special tanks in the basement. However, some of this $\mathrm{Hg}$ escaped these collection drains and entered into East For 5 of Poplar Creek (EFPC) (Fig. î).

Measurement of aquatic discharges of $\mathrm{Hg}$ from the Y-12 Plant began in April 1954. Annual releases of $\mathrm{Hg}$ (Fig. 2) are characteriz d by (1) a sharp increase in 1956 when fullscale lithium isotope processing began; (2) peak releases of 33 and 29 metric tons of inorganic $\mathrm{Hg}$ in 1957 and 1958, respectively; and (3) a sharp decline in $\mathrm{Hg}$ releases after 1958. Process changes in 1958 resulted in declining releases, and all production had ceased by 1963 . The total $\mathrm{Hg}$ release to the environment, including estimates for the 1950-to-1954 period, has been estimated to range from about 75 to 150 metric tons (Turner et al. 1985).

\section{PREVIOUS STUDIES}

The first comprehensive program to identify the transport, accumulation, and fate of contaminants released to off-site areas from the ORR began in the mid 1950 s in conjunction with the draining of WOL (Cottrell 1959). In this program, a gamma-radiation survey of surface sediments was conducted with a submersible Geiger-Mueller counting system. Most of the gamma radioactivity $\left({ }^{137} \mathrm{Cs},{ }^{60} \mathrm{Co}\right.$, rare-earth isotopes, and short-lived ${ }^{103} \mathrm{Ru}$ ) was found to have been deposited in the sediments of Watts Bar Reservoir, but some could be traced down the Tennessee River system to the Chickamauga Reservoir and beyond.

A second study was conducted over a 5-year period between 1960 and 1964. This "Clinch River Study" was a comprehensive physical, chemical, biological, and sedimentological investigation to deternire the environmental fate, ecological effects, and impact on man of radionuclides released to the Clinch River from ORNL (results are summarized by Struxness et al. 1967). Unfortunately, this intensive study was restricted primarily to the Clinch River itself, and the extent of contamination further downstream in Watts Bar Reservoir was not examined. Results indicated that soluble contaminants (e.g., ${ }^{3} \mathrm{H}$ and ${ }^{90} \mathrm{Sr}$ ) released from WOL were rapidly diluted in the Clinch River and flushed downstream without accumulating to any great extent (Cowser et al. 1966). Results from ${ }^{90} \mathrm{Sr}$ analysis of water samples and the shells of freshwater clams showed that concentrations of ${ }^{90} \mathrm{Sr}$ were detectable in the Tennessee 
River up to $5 \mathrm{CO}$ miles downstream from the release point (WOD) and could be accurately predicted on the basis of dilution (Nelson 1969).

Only about $21 \%$ of the ${ }^{137} \mathrm{Cs}, 9 \%$ of the ${ }^{60} \mathrm{Co}$, and less than $1 \%$ of the ${ }^{90} \mathrm{Sr}$ previously released from WOL had accumulated in the sediments of the Clinch River (Pickering et al. 1966; Struxness et al. 1967). As a consequence, Parker et al. (1966) concluded that very little of the radioactive material introduced into the Clinch River remained there in either the bottom sediments or in the biota. Struxness et al. (1967) concluded that the Clinch River functioned much like a pipe, transporting contaminants to sites farther downstream.

A third set of studies of the Clinch River sediments was conducted in the late 1970s to reevaluate the distribution of ${ }^{137} \mathrm{Cs}$ and to document levels of plutonium in the Clinch River sediments near the site proposed for the Clinch River Breeder $\bar{R}$ ictor (Oakes et al. 1982). Those results indicated that much of the ${ }^{137} \mathrm{Cs}$ previously deposited in the Clinch River had been eroded from the river sediments and transported dewnstream. Oakes et al. (1982) also reported that ${ }^{299,240} \mathrm{Pu}$ activities in the sediment were as high as $2 \mathrm{pCi} / \mathrm{g}(75 \mathrm{mBg} / \mathrm{g})$ in the Clinch River near the proposed reactor site. These ${ }^{239,240} \mathrm{Pu}$ concentrations in sediments do not pose a risk to human health that would warrant remediation (Hoffman et al. 1991).

To document levels of contamination in the sediments and soils near the proposed construction site of the New Blair Road Bridge across Poplar Creek, Olsen anr' Cutshall (1985) measured the vertical distribution of ${ }^{137} \mathrm{Cs}, \mathrm{Hg}_{1}$ and ${ }^{238} \mathrm{U}$ in a sediment core collected within the creek and in a soil core collected on its floodplain. Contaminant concentrations in the Poplar Creek sediment core are presented in Table 2 and indicate that $\mathrm{Hg}$ levels exceeded $450 \mu \mathrm{g} / \mathrm{g}$. Olsen and Cutshall (1985) attributed this high $\mathrm{Hg}$ concentration to discharges from the Y-12 Plant via EFPC. In addition, Olsen and Cutshal! (1985) suggested that the Y-12 Plant may also be a source of uranium to off-site areas because this sediment core was collected upstream of any K-25 discharge sites to Poplar Creek.

Before uranium enrichment operations at the K.-25 Site were halted, Ashwood et al. (1986) collected approximately 180 surface sediment samples and three sediment cores from the Poplar Creek and Clinch River system to identify contaminant source areas around the K.25 Site. Contaminant concentration levels in the three sediment cores are illustrated in Fig. 3. From these data, Ashwood et al. (1986) concluded that Poplar Creek sediments upstream of the K-25 Site were contaminated with $\mathrm{Hg}$, uranium, and ${ }^{60} \mathrm{Co}$ and suggested that the $\mathrm{X}-12$ Plant was a significant source of the $\mathrm{Hg}$ and uranium contamination and that releases from the Oak Ridge Sewage Treatment Facility were responsible for the ${ }^{60} \mathrm{Co}$. They also indicated that inputs of ${ }^{137} \mathrm{Cs}$ and ${ }^{60} \mathrm{Co}$ to off-site areas from the Y-12 Plant and from the City of Oak Ridge Sewage Treatment Plant via EFPC were relatively insignificant compared with the release of these two radionuclides from ORNL via WOL. As a consequence, much of the ${ }^{137} \mathrm{Cs}$ and ${ }^{60} \mathrm{Co}$ in the sediments near the K-25 Site were introduced via the Clinch River during periods of backflow into Poplar Creek.

The declassification of information on $\mathrm{Hg}$ discharged and unaccounted for from the $\mathrm{Y}-12$ Plant in 1983 led to increased scrutiny of downstream areas for $\mathrm{Hg}$ contamination (Elwood 1984) and to the organization of an interagency task force [Oak Ridge Task Force (ORTF)] to evaluate the associated threats of off-site contannination to human health, fish, and wildife. Most of the OR'TF investigative efforts were focused on the $\mathrm{Hg}$ contamination of EFPC and its floodplain. A total of 1526 water, sediment, and aquatic biota samples were collected by the Tennessee Valley Authority (TVA) to assess off-site mercury contamination derived from 
Table 2. Vertical distribution of mercury, ${ }^{87} \mathrm{Cs}$, and ${ }^{20} \mathrm{U}$ in a Poplar Creek sediment core collected vear Blair Rsad bridge (Olsen and Cutshall 1985)

\begin{tabular}{|c|c|c|c|c|}
\hline $\begin{array}{c}\text { Sediment } \\
\text { depth } \\
\text { (cm) }\end{array}$ & $\begin{array}{c}\text { Organic carbon } \\
(\%)\end{array}$ & $\begin{array}{c}\text { Mercury } \\
(\mu \mathrm{g} / \mathrm{g})\end{array}$ & $\begin{array}{r}{ }^{137} \mathrm{Cs} \\
(\mathrm{pCi} / \mathrm{g}) \\
\end{array}$ & $\begin{array}{r}{ }^{238} \mathrm{U} \\
(\mathrm{pCi} / \mathrm{g})\end{array}$ \\
\hline $0-2$ & 1.5 & 6.3 & $1.11 \pm 0.03$ & $\leq=2.8$ \\
\hline $2-4$ & 2.4 & 4.2 & $1.26 \pm 0.03$ & $\leq 2.8$ \\
\hline $4-8$ & 2.5 & 2.2 & $1.07 \pm 0.02$ & $3.0 \pm 1.1$ \\
\hline $8-12$ & 1.7 & 5.6 & $0.33 \pm 0.02$ & $\leq 2.8$ \\
\hline $12-16$ & 1.6 & 6.8 & $0.23 \pm 0.01$ & $3.5 \pm 0.9$ \\
\hline $16-20$ & & & $0.18 \pm 0.01$ & $\leq 2.8$ \\
\hline 20.24 & & & $0.30 \pm 0.04$ & $\leq 2.8$ \\
\hline $24-28$ & & & $0.34 \pm 0.04$ & $4.1 \pm 2.3$ \\
\hline $28-32$ & & & $0.38 \pm 0.05$ & $\leq 2.8$ \\
\hline $32-36$ & 1.3 & 14.0 & $0.79 \pm 0.06$ & $\leq 2.8$ \\
\hline $36-40$ & 1.3 & 22.6 & $2.63 \pm 0.11$ & $\leq 2.8$ \\
\hline $40-44$ & & & $1.33 \pm 0.08$ & $\leq 2.8$ \\
\hline $44-48$ & & & $0.68 \pm 0.05$ & $8.3 \pm 2.6$ \\
\hline $48-52$ & 1.6 & 18.0 & $0.90 \pm 0.07$ & $\leq 2.8$ \\
\hline $52-56$ & & & $1.33 \pm 0.08$ & $12.2 \pm 4.0$ \\
\hline $56-60$ & & & $1.10 \pm 0.08$ & $\leq 2.8$ \\
\hline $60-64$ & 1.4 & 38.3 & $0.82 \pm 0.04$ & $7.5 \pm 2.5$ \\
\hline $64-68$ & 0.7 & 54.4 & $1.33 \pm 0.08$ & $10.2 \pm 2.9$ \\
\hline $68-72$ & & & $0.87 \pm 0.07$ & $4.3 \pm 5.9$ \\
\hline $72-76$ & & & $1.08 \pm 0.08$ & $29.8 \pm 5.3$ \\
\hline $76-80$ & & & $1.01 \pm 0.06$ & $15.5 \pm 2.5$ \\
\hline $80-84$ & 1.1 & 460.0 & $1.06 \pm 0.07$ & $8.8 \pm 3.2$ \\
\hline $84-88$ & 1.1 & 220.0 & $1.53 \pm 0.08$ & $8.0 \pm 3.4$ \\
\hline $88-92$ & 0.9 & 40.0 & $1.71 \pm 0.08$ & $3.8 \pm 2.2$ \\
\hline $92-96$ & 1.0 & 56.0 & $4.64 \pm 0.13$ & $7.4 \pm 3.1$ \\
\hline $96-98$ & & & $2.81 \pm 0.11$ & $\leq 2.8$ \\
\hline
\end{tabular}




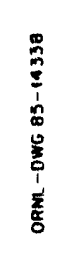
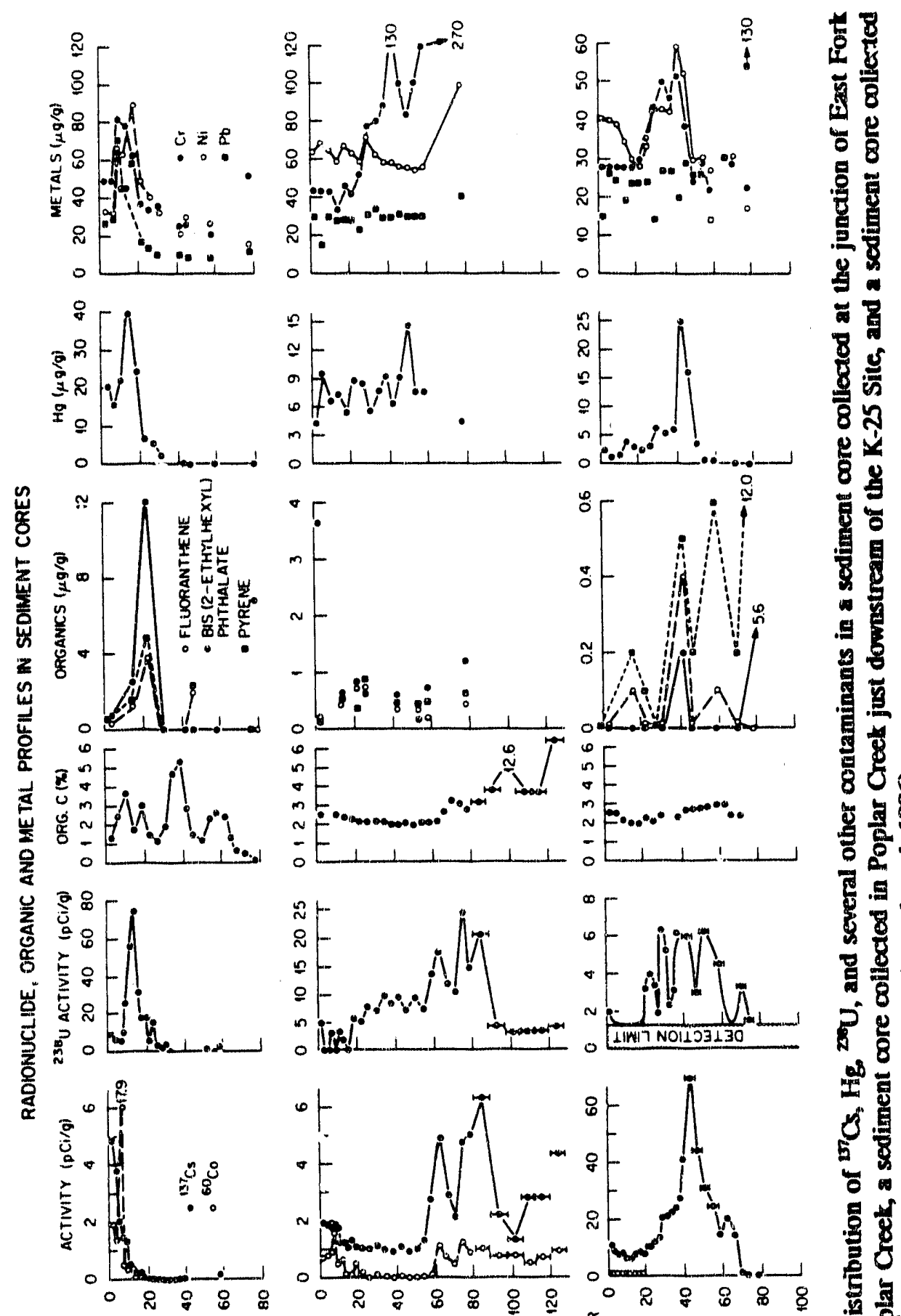

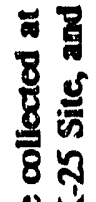

8
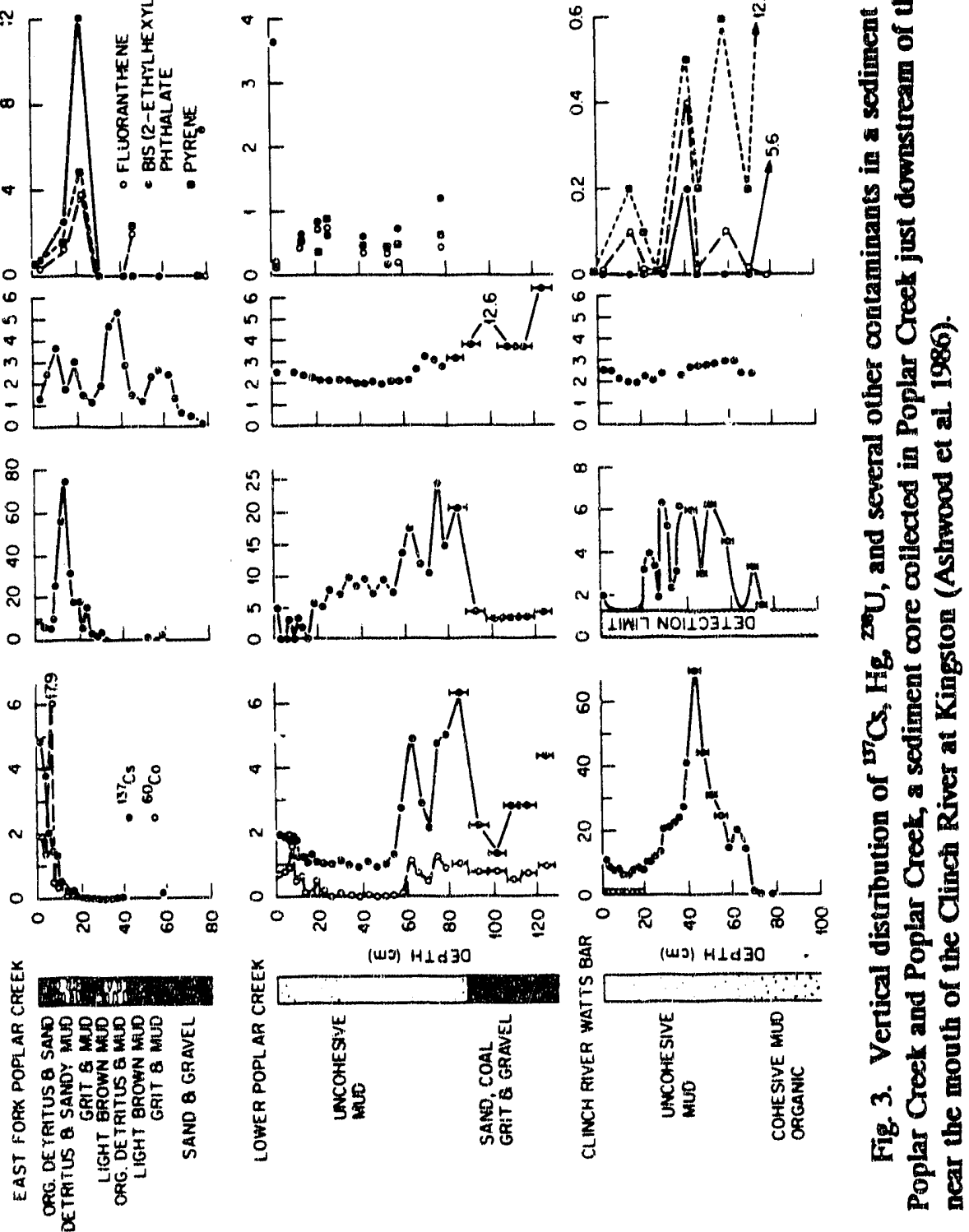
the $\mathrm{Y}-12$ releases (TVA 1986). This ORTF-supported study indicated that about $170,000 \mathrm{lb}$ ( 75 metric tons) of $\mathrm{Hg}$ had accumulated in the EFPC floodplain and that about $500 \mathrm{lb}$ (0.2 metric tons) were annually exported from EFPC to off-site areas.

In another ORTF-supported study, Turner et al. (1985) collected a total of seven sediment cores from Watts Bar and Chickamauga reservoirs to determine the downstream extent of the $\mathrm{Hg}$ contamination. They found that concentrations of $\mathrm{Hg}$ and ${ }^{137} \mathrm{Cs}$ were strongly correlated in sediment cores collected in Watts Bar Reservoir, exhibiting a peak concentration at sediment depths ranging from about 40 to $100 \mathrm{~cm}$ (Fig. 4). The highest concentrations of $\mathrm{Hg}(47 \mu \mathrm{g} / \mathrm{g})$ and of ${ }^{137} \mathrm{Cs}[152 \mathrm{pCi} / \mathrm{g}(5.6 \mathrm{~Bq} / \mathrm{g})]$ were found to occur in the core CRM-1, obtained at the mouth of the Clinch River near Kingston, Tennessee (Fig. 4). Hoffman et al. (1991) evaluated the risk to human health of these $\mathrm{Hg}$ and ${ }^{37} \mathrm{Cs}$ concentrations and found that, as long as the sediments remained in place, there was no imminent risk to human health. Further study is required to determine the need for remediation. Sediment cores collected from the lower Chickamauga Reservoir, however, contained $\mathrm{Hg}$ profiles that were more complex (in part a result of additional $\mathrm{Hg}$ inputs to the reservoir from a chloralkali plant located on the Hiwassee River) but contained ${ }^{137} \mathrm{Cs}$ profiles that were very similar to those in Watts Bar Reservoir (Turner et al. 1985).

On the basis of the results presented in Turner et al. (1985) and in Ashwood et al. (1986) and because most of the previous studies have been focused on the transport and fate of contaminants in EFPC, Poplar Creek, and the Clinch River downstream from the ORR, a need existed for a thorough sampling of Watts Bar Reservoir. All of the above previous studies have clearly shown that Poplar Creek and the Clinch River serve as pipelines for contaminants released from the ORR and that Watts Bar Reservoir serves as the major zone for contaminant accumulation. This conclusion is consistent with work in other river-reservoir systems, which have also indicated that reservoirs are very efficient traps for river-borne particles, nutrients, and contaminants and are sites of rapid sediment and contaminant accumulation (Dendy 1973; Ritchie, Hawks, and McHenry 1975; Olsen et al. 1981; Kinmel and Groeger 1986; Olsen et al. 1989a).

To address this need for characterizing the nature and extent of contamination in Watts Bar Reservoir, we have measured the vertical distribution of ${ }^{137} \mathrm{Cs}$ in more than 60 sediment cores (Fig. 5) and the concentration of ${ }^{137} \mathrm{Cs}$ in more than 190 surface sediment samples (Fig. 6) collected from Watts Bar Reservoir. The surface sediment samples were used to develop a map of sediment characteristics (Fig. 7) and to identify sites best suited for sediment coring. The objectives of this scoping study were to (1) use ${ }^{137} \mathrm{Cs}$ to evaluate the extent of contaminant accumulation in the reservoir sediments, (2) preliminarily identify highly contaminated off-site areas that could constitute potential risks to human health or the environment, and (3) estimate the retention efficiency of the reservoir for ${ }^{137} \mathrm{Cs}$ and, thereity, for other particle-associated contaminants.

As stated previously, this work represents the initial phase of the Clinch River RCRA Facility Investigation and provides important information for characterizing the nature and extent of ORR-derived contamination in off-site areas. 


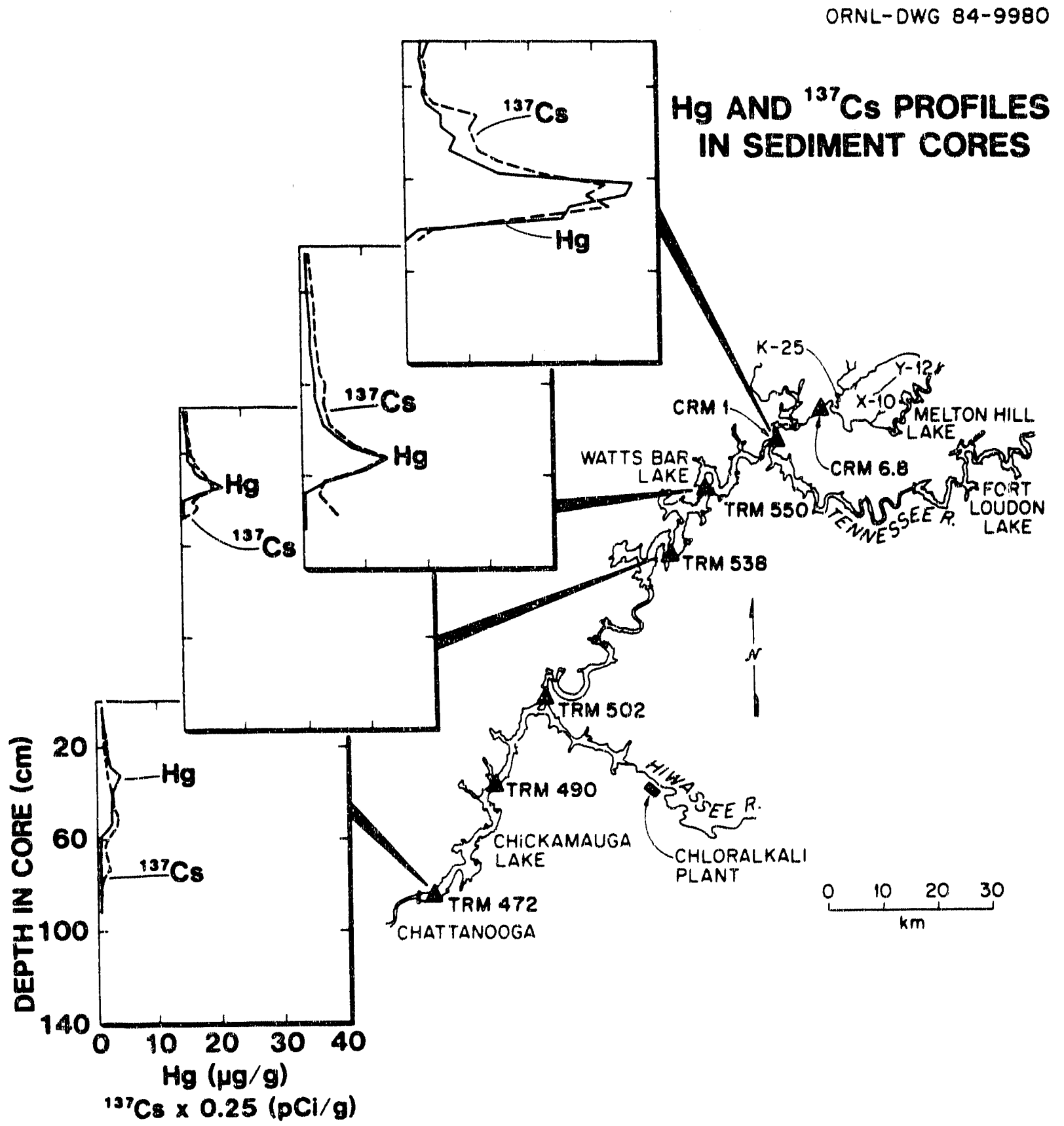

Fig. 4. Vertical profiles of ${ }^{157} \mathrm{Cs}$ and $\mathrm{Hg}$ for selocted sediment cores collected in the Tennesset River Reservair system (Turner et al. 1985). 
ORNL DWG 89M-13941

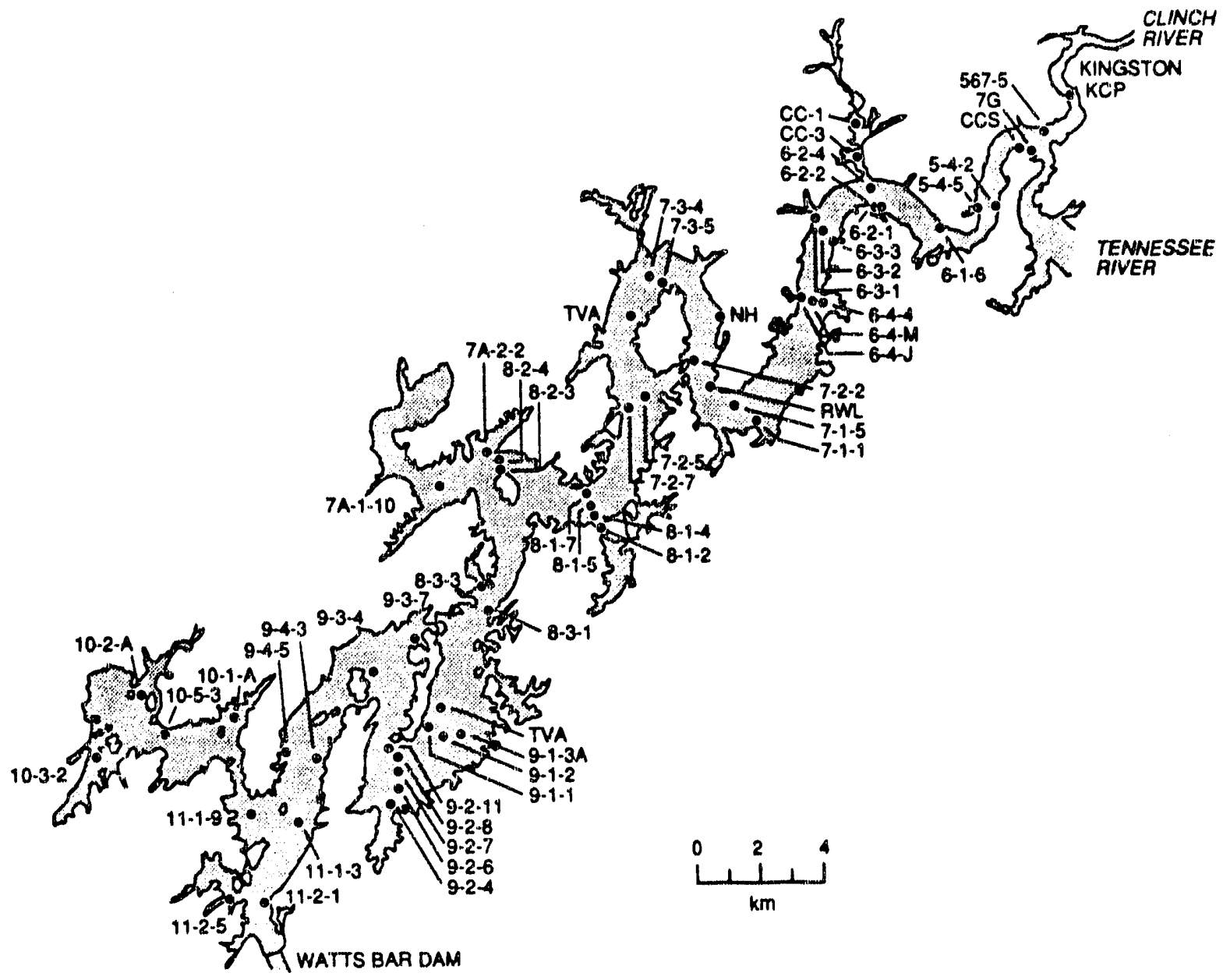

Fig. 5. Map of Watts Bar Reservoir indicating the locations and identifying the sediment cores collected in this study. 


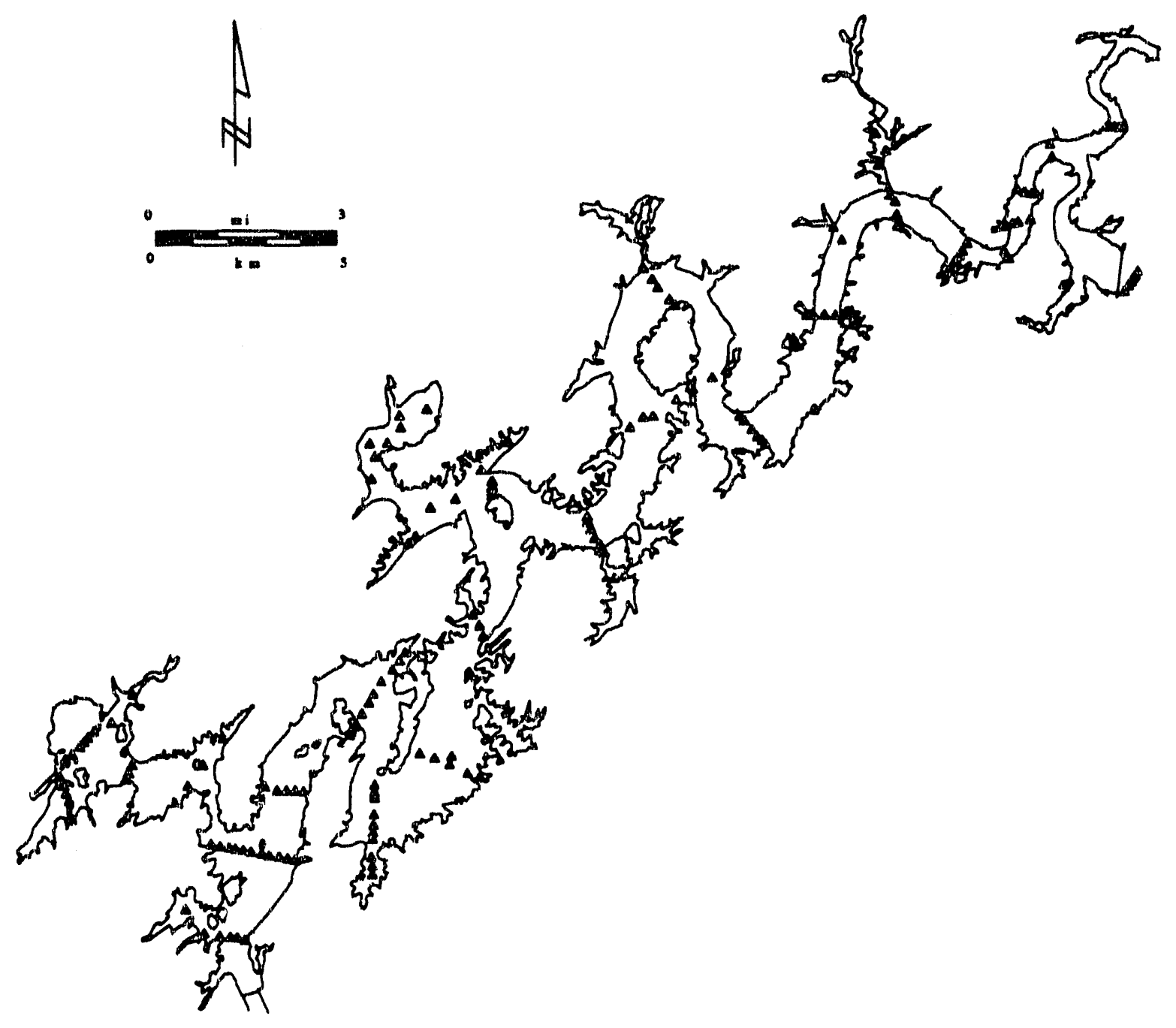

Fig 6. Map of Warts Bar Reservoir indicating the locations of the surface grab samples collected in this study. 


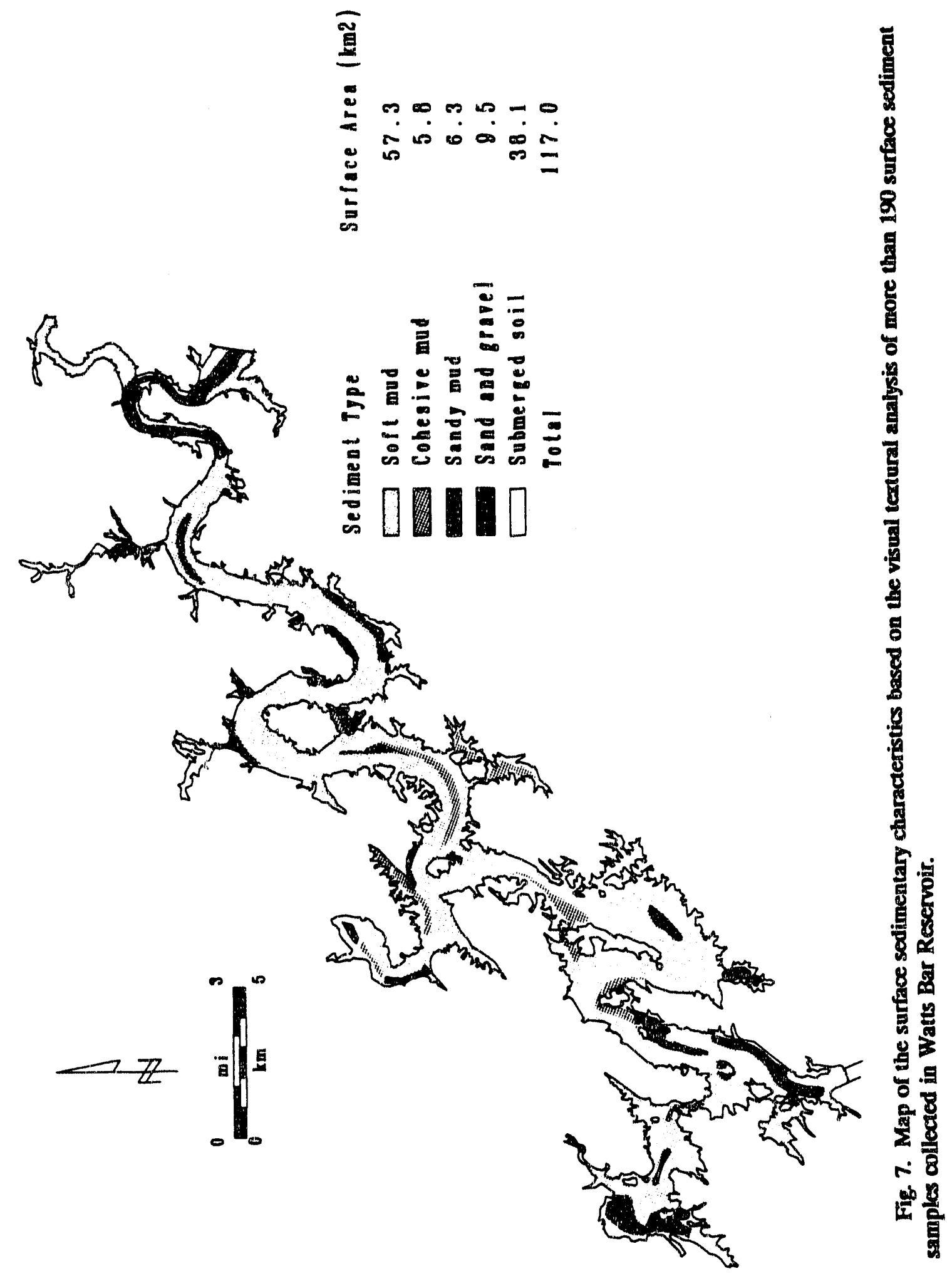




\section{MATERIALS AND METHODS}

Sampling locations in the Clinch River and Tennessee River system, were identified using TVA Navigation Charts with corresponding shore markers and/or channel buoys. In addition, prominent shore features (e.g., TVA power lines, bridges, and barge nuorings) were logged for each sampling location. Surface sediment samples were collected using a Ponar bottomgrab sampler $(17 \times 10 \times 7 \mathrm{~cm})$. The retrieved surface grab samples were immediately placed into labeled Marinelli beakers, which were placed directly on gamma detectors for radionuclide $\left({ }^{137} \mathrm{Cs}\right)$ analysis. These samples were used to characterize sediment types and distributions (gravel, sand, mud, and soil detritus) and to develop a map of surfacial contaminant concentrations.

Two types of coring devices were also used to obtain sediment profiles: a gravity corer and a vibracorer. The free-fall gravity corer (Wildco $\mathrm{KB}$ ) was equipped with a plastic liner that was $120 \mathrm{~cm}$ lol $\mathrm{g}$ and $4.7 \mathrm{~cm}$ in diameter. The corer was attached to a cable on a reel and allowed to free-fall Juring descent. This coring device was primarily used in areas where the reservoir water depth was greater than $10 \mathrm{~m}$. Upon retrieval, the plastic liner containing sediment was capped and then removed from the core barrel. The core was extruded from the liner and sectioned into either 1-, 2-, or 4-cm depth increments. These sections were sealed into plastic-lined aluminum cans and returned to the laboratory for radionuclide analysis.

The vibracorer consists of a vibrating head attached to an aluminum irrigation pipe, typically $7.2 \mathrm{~cm}$ in diameter. The vibrating head allows for greater penetration of the core pipe by thixotropic action. Sediment penetration by vibracoring is usually much greater than that obtainable by gravity coring and also minimizes compression of the sediment during sampling. Because pipe lengths greater than the depth on the water column are required in this operation, vibracores were collected only in areas where the water depth was less than $10 \mathrm{~m}$. After penetration into the sediment, the top of the core was plugged, and the entire core pipe was brought to the surface. The bottom was then plugged, and the excess core pipe was removed to facilitate handling and sediment extrusion. During exirusion the sediment core was sectioned into either 2 - or $4-\mathrm{cm}$ depth increments and sealed into labeled aluminum cans, as described previously.

\section{SEDIMENT ANALYSES}

Initially, the sediment samples collected in off-site areas were analyzed and screened for ${ }^{137} \mathrm{Cs}$ in our laboratory by gamma spectrometry. A few selected samples were also analyzed for ${ }^{60} \mathrm{Co}$ and naturally occurring ${ }^{210} \mathrm{~Pb}$, which was used to estimate sediment accumulation rates and to determine the age of the sediments.

The samples were radiochemically analyzed using germanium solid state detectors. A Nuclear Data 6700 microprocessor and later a Nuclear Data 9900 microprocessor acquisition system with spectra acquired in 4096 channels were used to record ${ }^{137} \mathrm{Cs}$ decays. Counting times for each sample ranged from 60 to $1000 \mathrm{~min}$ or longer, depending on the activity level present and the degree of precision desired. 
Each detector used for the initial screening was calibrated for photon energy versus channel number using isotopes of known gamma-ray energy (e.g., ${ }^{133} \mathrm{Ba},{ }^{137} \mathrm{Cs}$, and ${ }^{60} \mathrm{Co}$ ). Efficiency calibrations for the various geometries were performed using National Bureau of Standards (NBS) reference sources (e.g., Amersham's QCY 46 mixed gamma solution). A description of the calibration procedures has been presented elsewhere (Larsen and Cutshall 1981). After counting, the sample was weighed, oven-air dried $\left(60^{\circ} \mathrm{C}\right)$ for several days, and weighed again to determine both the wet and dry weight. The $60^{\circ} \mathrm{C}$ drying temperature was selected to prevent volatilization of other types of contaminants (e.g., Hg and PCBs.) Wet and dry weights of the samples were used to calculate porusity and activity concentrations.

Various techniques were used to provide quality assurance/quality control for the radionuclide measurements. Detector performance was evaluated weekly by counting a source of known activity and comparing the value obtained with the reported value. These values were then plotted on a control chart to keep a track record of detector performance. In addition, we routinely participated in the Quality Assurance/Quality Control Radioanalytical Program at the EPA Environmental Monitoring Systems Laboratory in Las Vegas, Nevada (EMSL-LV). Samples received from the program are routinely analyzed by gamma aay spectrometry as cross-checks or blind samples. Table 3 illustrates the performance for each of our three detectors $(A, B$, and $\widetilde{C}$ ) in the April 20,1987, laboratory intercomparison. In addition, certified reference materials from the NBS were also anaiyzed. Table 4 illustrates the analysis of standard reference material (SRM) NBS SRM 4353 Rocky Flats Soil contained in our aluminum can geometry.

Table 3. EPA EMSL-LV Intercomparison Study, April 1987, Marinelli beaker geometry

$(\mathrm{pCi} / \mathrm{L} \pm \mathrm{l \sigma})$

\begin{tabular}{|c|c|c|c|c|c|c|}
\hline & \multicolumn{4}{|c|}{ Environmental Sciences Division detector } & \multirow{2}{*}{$\begin{array}{c}\text { EPA } \\
\text { standard } \\
\text { value }\end{array}$} & \multirow{2}{*}{$\begin{array}{c}\text { Mear for } \\
\text { participating } \\
\text { labs }\end{array}$} \\
\hline & A & B & C & Mean & & \\
\hline${ }^{\infty} \mathrm{Co}$ & 8.0 & 8.0 & 7.0 & $7.7 \pm 0.6$ & $8.0 \pm 5.0$ & $9.0 \pm 2.0$ \\
\hline${ }^{134} \mathrm{Cs}$ & 18.0 & 18.0 & 16.0 & $17.3 \pm 1.2$ & $20.0 \pm 5.0$ & $18.2 \pm 2.6$ \\
\hline${ }^{137} \mathrm{Cs}$ & 15.0 & 15.0 & 14.0 & $14.7 \pm 0.6$ & $15.0 \pm 5.0$ & $15.7 \pm 2.2$ \\
\hline
\end{tabular}

After initial screening by gamma spectrometry, selected samples (hermetically sealed in plastic-lined aluminum cans) were sent, through an appropriate chain of custody, to the ORNL Analytical Chemistry Division (ACD) for analysis of total Hg using ACD Preparation Method 10915 and ACD Analytical Method 1214922. In addition to routine quality assurance/quality control procedures used by ACD, an SRM (NBS SRM 1646, Estuarine Sediment) was analyzed with one batch of core samples. The results $(0.065$ and $0.067 \mu \mathrm{g} / \mathrm{g}$, respectively, for the two duplicates) were in good agreement with the certified value $(0.063$ $\pm 0.012 \mu \mathrm{g} / \mathrm{g}$ ) for this material. 
Table 4. National Bureau of Standards SRM 4353 Rocky Flats soil, aluminum can geometry"

$(\mathrm{pCi} / \mathrm{g} \pm \mathrm{l \sigma})$

\begin{tabular}{|c|c|c|c|c|c|}
\hline & \multicolumn{4}{|c|}{ Environmental Sciences Division detector } & \multirow{2}{*}{$\begin{array}{l}\text { NBS } \\
\text { standard } \\
\text { value }\end{array}$} \\
\hline & A & B & $\mathrm{C}$ & Mean & \\
\hline${ }^{137} \mathrm{Cs}$ & $0.46 \pm 0.03$ & $0.45 \pm 0.05$ & $0.49 \pm 0.04$ & $0.47 \pm 0.02$ & $0.48 \pm 0.01$ \\
\hline${ }^{40} \mathrm{~K}$ & $18.8 \pm 0.4$ & $18.6 \pm 0.5$ & $19.4 \pm 0.6$ & $18.9 \pm 0.6$ & $19.5 \pm 0.6$ \\
\hline
\end{tabular}

aDecay corrected to Dec. $15,1980$.

The vertical distribution of ${ }^{90} \mathrm{Sr}$ was also measured in one of the sediment cores (core 567.5 in Fig. 5) collected at the mouth of the Clinch River near Kingston. The samples were radiochemically analyzed following the procedures established at the DOE Environmental Measurements Laboratory (E-SR-01). A ${ }^{85} \mathrm{Sr}$ tracer was added to each sediment sample for jield determinations. The ${ }^{90} \mathrm{Sr}$ activity was measured with a low-background gas-flow proportional bet a counter, and accuracy was assessed with a ${ }^{90} \mathrm{Sr}$ standard supplied by EPA.

\section{WATER ANALYSES}

To quantity the distribution of ${ }^{137} \mathrm{Cs}$ and $\mathrm{Hg}$ between dissolved and particulate phases, several large-volume (400- to $800-\mathrm{L}$ ) water samples were collected at various locations in Watts Bar Reservoir. Suspended particles $(>0.45 \mu \mathrm{m})$ were removed from these large-volume samples by continuous-flow centrifugation. The suspended matter was dried, weighed, and analyzed for ${ }^{137} \mathrm{Cs}$ by the procedures described above and analyzed for total $\mathrm{Hg}$ by the ACD.

After centrifugation, each large-volume water sample was acidified with $\mathrm{HCl}$ to a $\mathrm{pH}$ of approximately 2 , and stable $\mathrm{Cs}$ and $\mathrm{Fe}$ (and occasionally $\mathrm{Pb}, \mathrm{Co}, \mathrm{Be}$, and ${ }^{242} \mathrm{Pu}$ ) were added as carriers and yield tracers. The yield tracers were allowed to equilibrate for 6 to $8 \mathrm{~h}$, and dissolved radiocesium was removed from the large-vnlume water sample by sorption on $a$ cation-exchange resin (ammonium molybdophosphate). The resin was added on the same day of sample collection and was allowed to settle out of the sample overnight. For selected samples the water was then transferred to another $1000-\mathrm{L}$ tank, and the $\mathrm{pH}$ was adjusted to about 10 with $\mathrm{NaOH}$ to allow the iron to precipitate. Dissolved ${ }^{60} \mathrm{Co},{ }^{7} \mathrm{Be},{ }^{210} \mathrm{~Pb}$, and plutonium isotopes were removed from these samples by coprecipitation with or sorption on the $\mathrm{Fe}(\mathrm{OH})_{3}$ precipitate. Quantification of the yield tracers by atomic absorption spectrometry indicated that 70 to $100 \%$ of the $\mathrm{Cs}, \mathrm{Be}, \mathrm{Pb}$, and $\mathrm{Co}$ could be recovered by these procedures. The radionuclide activities for each sample were yield corrected according to the actual recovery.

The dissolved and particulate plutonium analyses were conducted by $\mathrm{M}$. Thein (ORNL Environmental Compliance and Health Protection Division). These analyses involved dissolution with $\mathrm{HCl}$, coprecipitation with calcium oxalate, radiochemical separation with ion-exchange columns, electrodeposition onto stainless steel disks, and alpha spectrometry with silicon surface-barrier detectors. The samples were alpha counted for about $21 \mathrm{~d}$, and yields were evaluated using a ${ }^{242} \mathrm{Pu}$ tracer. Plutonium-239 and -240 activities are collectively 
reported because the energies of the alpha particles produced by the decay of ${ }^{240} \mathrm{Pu}$ (6580-year half-life) cannot be resolved from those produced by the decay of ${ }^{239} \mathrm{Pu}$ (24,400-year half-life) by alpha spectrometry.

Two 500-mL water samples were collected at the same time and at two locations in Watts Bar Reservoir to measure the concentration of dissolved $\mathrm{Hg}$ in the water column. These samples were filtered through $0.2-\mu \mathrm{m}$ filters, and the filtrates were analyzed for total $\mathrm{Hg}$ by ACD. 


\section{RESULTS AND DISCUSSION}

Some contaminants and radionuclides (such as ${ }^{3} \mathrm{H},{ }^{90} \mathrm{Sr}$, and ${ }^{31} \mathrm{I}$ ) are relatively soluble in freshwater systems, and consequently their transpont and biogeochemical fate are mediated by water movements and biological uptake from the water phase. Most contaminants (e.g., $\mathrm{Hg},{ }^{137} \mathrm{Cs},{ }^{50} \mathrm{Co}$, and ${ }^{239,240} \mathrm{Pu}$ ), however, are chemically and biologically reactive and rapidly become associated with particles in freshwater systems. Consequently, the transport and biogeochemical fate of these contaminants are primarily governed by particle dynamics.

The tendency for a contaminant to become associated with particles in aquatic systems is expressed quantitatively by the distribution coefficient $\left(K_{d}\right)$, defined as

$$
\boldsymbol{x}_{d}=\frac{C_{1}}{C_{w}},
$$

where $C_{p}$ is the concentration of a specific contaminant associated with a given weight of particles $(\mu \mathrm{g} / \mathrm{g})$ and $C_{w}$ is the concentration of the contaminant in an equal weight of water $(\mu \mathrm{g} / \mathrm{mL})$. Ideally, this ratio is a measure of the reversible equilibrium partitioning of a contaminant between dissolved and particulate phases and would be a constant. Because most natural environments (including Watts Bar Reservoir) are affected by short-term physical, chemical, and biological processes, chemical equilibrium is continually adjusting and rarely attained.

\section{CONTAMINANTS IN THE WATER COLUMN}

Dissolved and particulate concentrations for $\mathrm{Hg},{ }^{137} \mathrm{Cs},{ }^{60} \mathrm{Co},{ }^{7} \mathrm{Be},{ }^{299,200} \mathrm{Pu}$, and ${ }^{238} \mathrm{Pu}$ in the water column of Watts Bar Reservoir and their calculated particle-to-water distribution coefficients are listed in Table 5. These ${ }^{137} \mathrm{Cs},{ }^{60} \mathrm{Co},{ }^{239,240} \mathrm{Pu}$, and $\mathrm{Hg}$ concentrations are comparable to values found in previous studies in the Clinch River. Hoffman et al. (1991) have shown these concentrations to pose no inminent risk to human health, especially if the deep sediment is not subjected to dredging. The particle-to-water distribution coefficients for both ${ }^{137} \mathrm{Cs}$ and $\mathrm{Hg}$ range between $1 \times 10^{5}$ to $5 \times 10^{5}$ (Table 5). This indicates that both contaminants are particle-reactive and that the dissolved concentrations of ${ }^{137} \mathrm{Cs}$ and $\mathrm{Hg}$ are about 10,000 times lower than the concentration on suspended particles and surface sediments.

The data presented for the large-volume water samples collected at the mouth of the Clinch River on December 1, 5, and 17, 1986 (Table 5), were obtained to (1) provide information on the partitioning of these contaminants between dissolved and particulate phases and (2) determine whether the abnormally high concentrations of ${ }^{60} \mathrm{Co}$ that were measured by others in WOL on November 25-26, 1986, could be traced into Watts Bar Reservoir.

On December 1, the dissolved concentration of ${ }^{60} \mathrm{Co}$ was $0.024 \mathrm{pCi} / \mathrm{L}(0.9 \mathrm{mBg} / \mathrm{L})$ near Kingston City Park, and the concentration of ${ }^{60} \mathrm{Co}$ on the particulate matter was $1.1 \mathrm{pCi} / \mathrm{g}$ $\left(41 \mathrm{mBq} / \mathrm{g}\right.$ ) (Table 5). Because the ${ }^{60} \mathrm{Co}$ concentration on bottom sediments in this area ranges from about 0.8 to $1.2 \mathrm{pCi} / \mathrm{g}$ ( 30 to $45 \mathrm{mBg} / \mathrm{g}$ ), the ${ }^{60} \mathrm{Co}$ concentration measured on the particulate matter (1.1 pCi/g) is typical for resuspended bottom sediments and does not reflect 
Table 5. Contaminant distributions between aqueous and particulate phases

\begin{tabular}{|c|c|c|c|c|c|}
\hline Date & Nuclide & $\begin{array}{c}\text { Suspended } \\
\text { load } \\
\text { (mg/L) }\end{array}$ & $\begin{array}{l}\text { Dissolved } \\
(\mathrm{fCi} / \mathrm{L})\end{array}$ & $\begin{array}{l}\text { Particulate } \\
\text { (pCi/g) }\end{array}$ & $\begin{array}{c}\text { Distribution }^{n} \\
K_{d}\end{array}$ \\
\hline \multicolumn{6}{|c|}{ City of Kingston-Mouth of the Clinch River } \\
\hline \multirow[t]{5}{*}{$12 / 1 / 86$} & ${ }^{60} \mathrm{Co}$ & 14 & 24 & 1.1 & $5 \times 10^{4}$ \\
\hline & ${ }^{137} \mathrm{Cs}$ & & 35 & 6.8 & $2 \times 10^{5}$ \\
\hline & ${ }^{7} \mathrm{Be}$ & & 92 & 5.4 & $6 \times 10^{4}$ \\
\hline & $209,200 \mathrm{Pu}$ & & 0.38 & 0.04 & $1 \times 10^{5}$ \\
\hline & ${ }^{256} \mathrm{Pu}$ & & 0.11 & 0.005 & $5 \times 10^{4}$ \\
\hline \multirow[t]{4}{*}{$12 / 5 / 86$} & ${ }^{\infty} \mathrm{Co}$ & 11 & 250 & 4.3 & $2 \times 10^{4}$ \\
\hline & ${ }^{137} \mathrm{Cs}$ & & 49 & 14.6 & $3 \times 10^{5}$ \\
\hline & ${ }^{\prime} \mathrm{Be}$ & & 65 & 5.3 & $8 \times 10^{4}$ \\
\hline & $\mathrm{Hg}(\mathrm{ppb})^{b}$ & & 0.005 & 2360 & $5 \times 10^{5}$ \\
\hline \multirow[t]{3}{*}{$12 / 17 / 86$} & ${ }^{\infty} \mathrm{Co}$ & 7 & 215 & 7.3 & $3 \times 10^{4}$ \\
\hline & ${ }^{137} \mathrm{Cs}$ & & 103 & 26.5 & $3 \times 10^{5}$ \\
\hline & ${ }^{7} \mathrm{Be}$ & & 76 & 8.0 & $1 \times 10^{5}$ \\
\hline \multicolumn{6}{|c|}{ Thief Neck-Watts Bar Reservoir } \\
\hline \multirow[t]{3}{*}{$12 / 22 / 86$} & ${ }^{\circ} \mathrm{Cs}$ & 7 & 12 & 0.9 & $8 \times 10^{4}$ \\
\hline & ${ }^{137} \mathrm{Cs}$ & & 17 & 5.1 & $3 \times 10^{5}$ \\
\hline & ${ }^{7} \mathrm{Be}$ & & 78 & 8.7 & $1 \times 10^{3}$ \\
\hline \multicolumn{6}{|c|}{ Mouth of White Creek-Watts Bar Reservoir } \\
\hline $3 / 9 / 89$ & $\mathrm{Hg}(\mathrm{ppb})^{b}$ & 21 & 0.004 & 510 & $1 \times 10^{5}$ \\
\hline
\end{tabular}

- Particle-to-water distribution

$K_{d}=\frac{\text { concentration per kilogram of particles }}{\text { concentration per liter of water }}$.

${ }^{b} \mathrm{ppb}=$ parts per billion or $\mu \mathrm{g} /$ 
any recent additional inputs. Likewise, the concentrations of ${ }^{137} \mathrm{Cs}, \mathrm{Hg}$, and plutonium in the water and on the particulate matter were not abnormally higher than the values expected from the resuspension of river-reservoir sediments, primary productivity, and equilibrium particle-to-water distributions.

On December 5 (about $10 \mathrm{~d}$ after the ${ }^{60} \mathrm{Co}$ release was observed in WOL), the dissolved concentration of ${ }^{60} \mathrm{Co}$ increased by an order of magnitude and particulate concentrations of ${ }^{60} \mathrm{Co}$ increased by a factor of 4 (Table 5). On December 17 , the dissolved concentration of ${ }^{60} \mathrm{Co}$ began to decrease but particulate ${ }^{60} \mathrm{Co}$ concentrations continued to increase by another factor of 2 (Table 5). These data indicate that it takes about 2 to 3 weeks before the ${ }^{60} \mathrm{Co}$ released into White Oak Creek is transported via the Clinch River into Watts Bar Reservoir. In addition, the time-delayed increase in the particulate ${ }^{60} \mathrm{Co}$ and ${ }^{137} \mathrm{Cs}$ concentrations at Kingston (Table 5) imply that particle deposition and resuspension processes cause the maximum water column concentration of particle-reactive radionuclides to nccur at Kingston about 1 month after release into WOL. This delay may be even longer during the summer and fall, when rainstorm resuspension events occur less frequently.

Comparison of the suspended-particulate ${ }^{137} \mathrm{Cs}$ and $\mathrm{Hg}$ concentration data measured at the mouth of the Clinch River with respective data collected at Thief Neck and White Creek (Table 5) indicate that the concentrations for both of these contaminants are reduced by a factor of about 3. This decrease is also apparent in the ${ }^{137} \mathrm{Cs}$ and $\mathrm{Hg}$ concentrations in surface sediments (Appendix A). Concentrations of ${ }^{137} \mathrm{Cs}$ in soft-mud surface sediments at the mouth of the Clinch River average about $7.0 \mathrm{pCi} / \mathrm{g}(260 \mathrm{mBq} / \mathrm{g})$, whereas ${ }^{137} \mathrm{Cs}$ concentrations in soft-mud surface sediments below the confluence of the Tennessee River average about $2.5 \mathrm{pCi} / \mathrm{g}(90 \mathrm{mBq} / \mathrm{g})$. This trend probably reflects the dilution of Clinch River particulate material with particles from other sources (primarily the Tennessee River).

Finally, it should be noted that concentrations of ${ }^{20,240} \mathrm{Pu}$ and ${ }^{238} \mathrm{Pu}$ in the water column of Watts Bar Reservoir near Kingston are also reported in Table 5. These dissolved and particulate plutonium concentrations are about a factor of 5 higher than respective concentrations that have been measured by us and others in other river-reservoir systems along the east coast of the United States, including the Savannah River downstream from the DOE Savannah River Plant (Olsen et al. 1989b). In addition, the ratio of ${ }^{238} \mathrm{Pu}$ to ${ }^{239,260} \mathrm{Pu}$ on the suspended particles in Watts Bar Reservoir (0.13) is about a factor of 3 higher than the ${ }^{138} \mathrm{Pu}$ to ${ }^{239,240} \mathrm{Pu}$ ratio in global fallout $(0.045)$ delivered to mid-latitude areas of the Northern Hemisphere. This suggests that some of the plutonium disposed of or stored on the ORR is being transported into off-site areas. Preliminary screening assessments, however, indicate that the measured concentrations of ${ }^{239.200} \mathrm{~Pb}$ and ${ }^{238} \mathrm{Pu}$ in water and sediment are far below any established level of risk that would be of concern for the protection of human health (Hoffman et al. 1991).

\section{CONTAMTNANTS IN BOTTOM SEDIMENTS}

Sorption onto suspended particles and sediment deposition are the principal mechanisrns by which many chemically reactive contaminants (such as ${ }^{137} \mathrm{Cs}$ and $\mathrm{Hg}$ ) are removed from the water column and accumulated in the bottom sediments. Although burial in sediments helps to isolate these contaminants from human and biotic contact, contaminant burial may be disturbed in some areas by sediment resuspension, sediment mixing, or diagenetic. remobilization processes. Unfortunately, however, quantitative measurements of the extent 
of removal, burial, and remobilization in any field system are extremely difficult because of the complex physical, chemical, and biological interactions that affect contaminant fate and their extreme variability with space and time. One of the tools available for tracing and quantifying these interactions is the distribution of a radionuclide with a known source and history of input into the system. In this scoping study, we have used the distribution of ${ }^{137} \mathrm{Cs}$ as a cost-effective tracer to identify where sediments and particle-reactive contaminants are accumulating in the Clinch River and Watts Bar Reservoir system. This approach will allow for more-efficient characterization of contamination in off-site areas and, therefore, reductions in time and costs.

\section{RADIONUCLIDE DISTRIBUTIONS}

The distribution of ${ }^{137} \mathrm{Cs}$ concentrations in the surface sediments of Watts Bar Reservoir is illustrated in Fig. 8. A comparison of this figure with the map of sedimentary characteristics (Fig. 7) indicates that the concentrations of ${ }^{137} \mathrm{Cs}$ are highest in the soft-mud areas and lowest in the sand/gravel and submerged soil areas of the reservoir.

The vertical distribution of ${ }^{137} \mathrm{Cs}$ in Watts Bar Reservoir sediment cores is strongly correlated with the historical record of ${ }^{137} \mathrm{Cs}$ discharges from WOL, exhibiting a large subsurface peak coincident with the draining of WOL in the mid-1950s (Fig. 9). The depth of this subsurface peak and the thickness of ${ }^{137} \mathrm{Cs}$-contaminated sediment vary with the rate of sediment accumulation. In areas of rapid sediment accumulation, such as in the upper portion of the reservoir (core 567.5 in Fig. 9) and along the old river channel (cores 6-2-1, 8-1-4, and 9-4-3 in Fig. 9), the highest ${ }^{137} \mathrm{C}$ s concentrations occur at sediment depths as great as $80 \mathrm{~cm}$ below the surface. In areas of slower sediment accumulation, such as along the reservoir margins (cores KCP, 8-2-3 and 11-2-1 in Fig. 9), the highest ${ }^{137} \mathrm{Cs}$ concentrations can often occur much nearer the sediment surface. Hoffman et al. (1991) evaluated the risk to human health of ${ }^{137} \mathrm{Cs}$ concentrations of this magnitude and found that, as long as the sediments remained in place, there was no imminent risk to human health. Further study, however, is required to determine the need for remediation.

To document the fact that the ${ }^{137} \mathrm{Cs}$ peak in Watts Bar Reservoir sediments actually reflects the draining of WOL in the mid-1950s, the rate of sediment accumulation (and thus the age of the sediment at various depths) was independently determined using the ${ }^{210} \mathrm{~Pb}$ chronological technique. Lead-210, a naturally occurring radionuclide that has a 22-year half-life, has been extensively used for dating sediment and soil samples deposited during the past 100 years. Although ${ }^{210} \mathrm{~Pb}$ is produced in sediments from the decay of ${ }^{20} \mathrm{Ra}$, much of the ${ }^{210} \mathrm{~Pb}$ in surface sediments is a result of its removal from the atmosphere via precipitation scavenging and washout. By measuring ${ }^{210} \mathrm{~Pb}$ and ${ }^{220} \mathrm{Ra}$ profiles in sediment cores, chronological information can be obtained from the decline (by radioactive decay) of atmospherically derived ${ }^{210} \mathrm{~Pb}$ (termed excess ${ }^{210} \mathrm{~Pb}$ ) in the sediment.

Vertical profiles of ${ }^{137} \mathrm{Cs},{ }^{60} \mathrm{Co}$, and excess ${ }^{210} \mathrm{~Pb}$ with sediment depth are illustrated for core 567.5 in Fig. 10. The slope of the line through the data for excess ${ }^{210} \mathrm{~Pb}$ indicates a sediment accumulation rate of about $2.7 \mathrm{~cm} /$ year.

Because this core was collected in August 1986, such a sedimentation rate implies that the 80- to 84-cm depth increment and ${ }^{137} \mathrm{Cs}$ peak were deposited around 1955-1956, which is coincident with the draining of WOL. These data also imply that particle-associated 


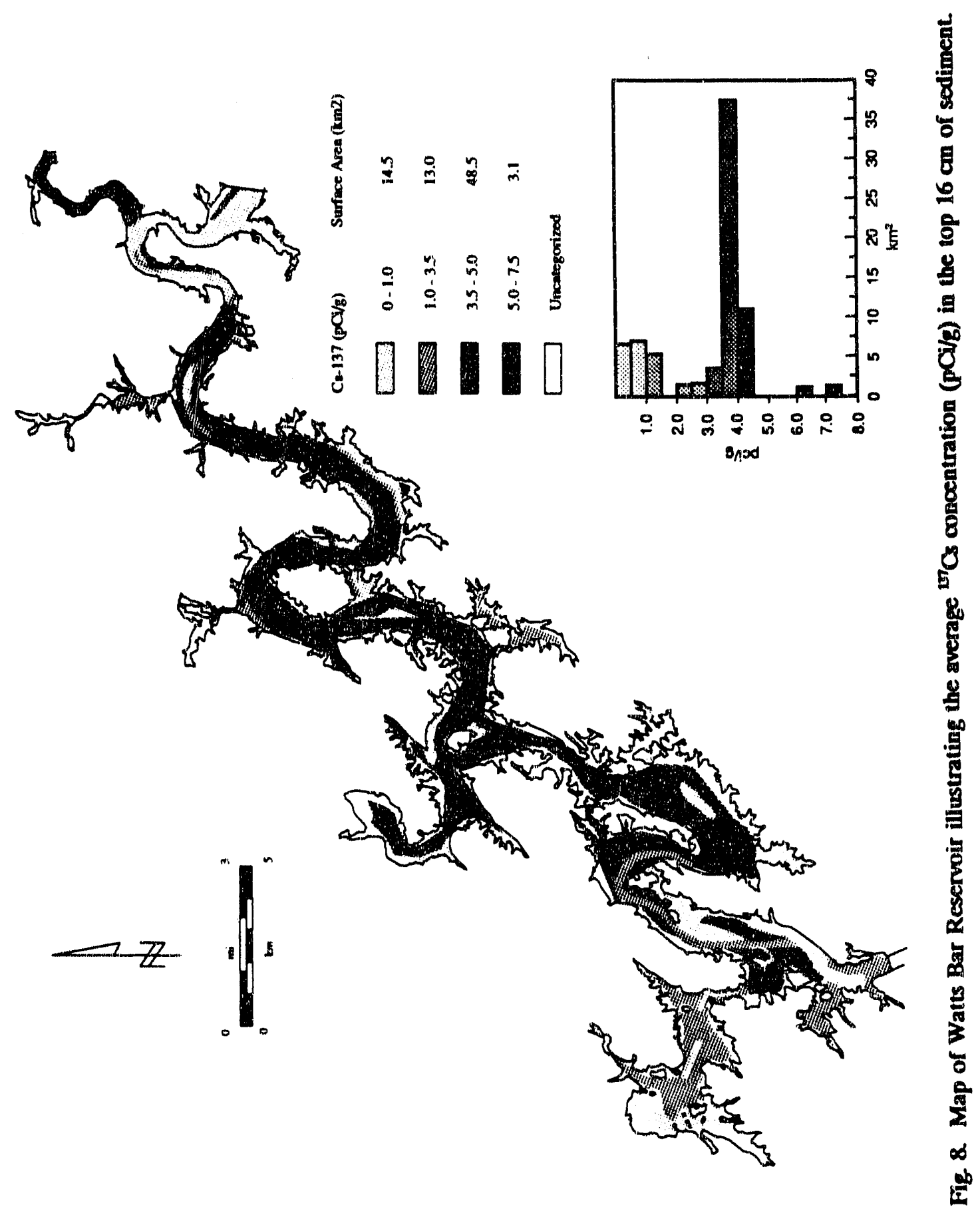



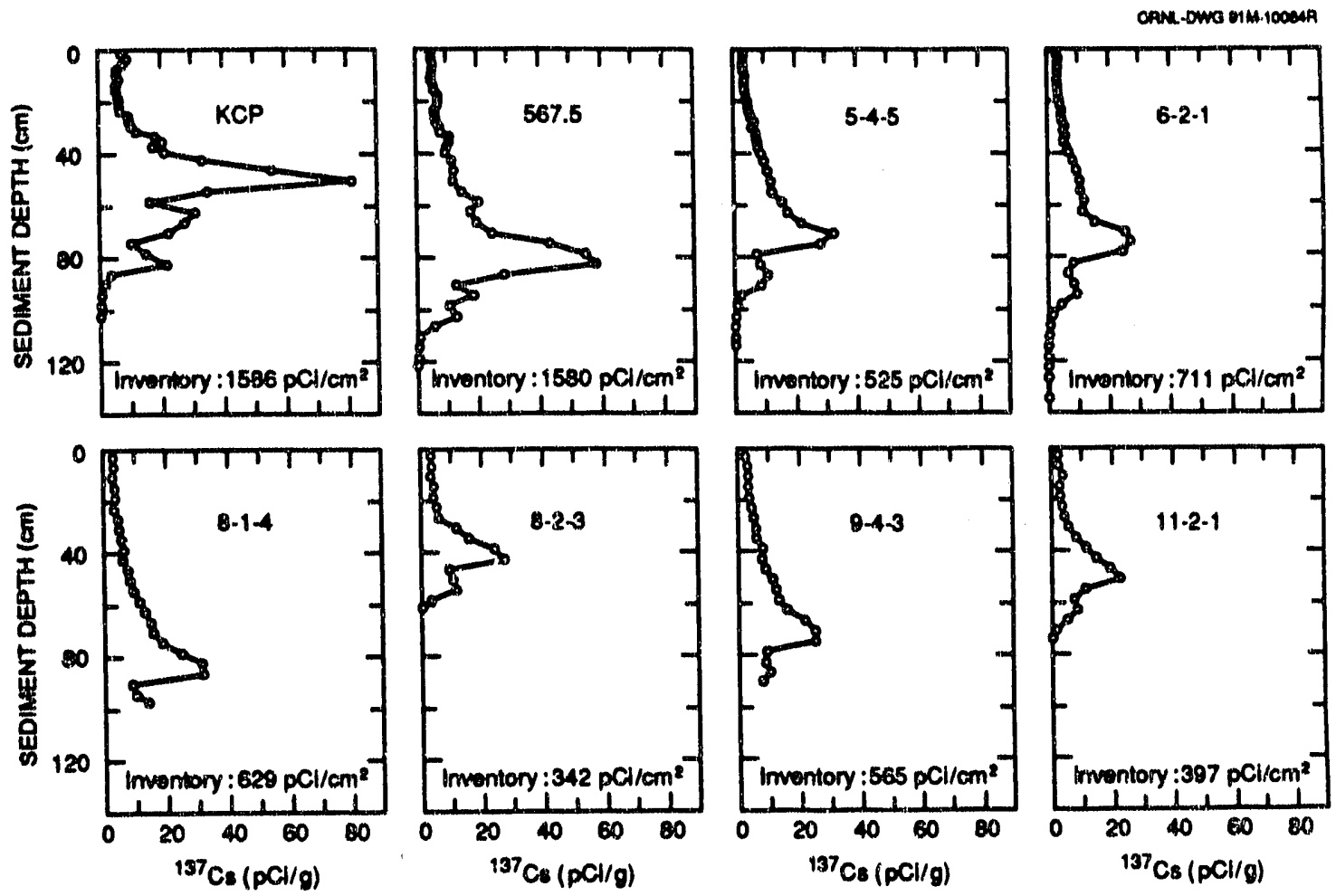

Fig. 9. Vertical distribution of ${ }^{27} \mathrm{Cs}$ with sediment depth in cores $\mathrm{KCP}, 567.5,5-4-5,6-2-1,8-1-4$, 8-2-3, 2-4-3, and 11-2-1. Cores KCP and 567.7 were collected near the mouth of the Clinch River, and the others were collected in a downstream sequence to Watts Bar Dam (soe Fig 5 for core locations).

radionuclides released from WOL are transported to and deposited in Watts Bar Reservoir within a year after their discharge. Because of the short half-life of ${ }^{60} \mathrm{Co}$ (about 5 years), its vertical profile in the sediments is different from that of ${ }^{137} \mathrm{Cs}$. Most of the ${ }^{60} \mathrm{Co}$ deposited with sediments in 1955-1956 has decayed, and consequently ${ }^{60} \mathrm{Co}$ concentrations are highest in the recently deposited surface sediments.

The vertical distribution of ${ }^{90} \mathrm{Sr}$ in sediment core 567.5 is illustrated in Fig. 11 . This ${ }^{90} \mathrm{Sr}$ profile shows a peak concentration of $580 \mathrm{pCi} / \mathrm{kg}(22 \mathrm{~Bq} / \mathrm{kg})$ at a sediment depth of 80 to $84 \mathrm{~cm}$ and a secondary peak [325 pCi/kg $(12 \mathrm{~Bq} / \mathrm{kg})]$ at 36 to $40 \mathrm{~cm}$. A comparison of this profile with the vertical distribution of ${ }^{137} \mathrm{Cs}$ (Fig. 10) indicates that the ${ }^{90} \mathrm{Sr}$ peak at about 80 to $84 \mathrm{~cm}$ is coincident with a peak in the ${ }^{137} \mathrm{Cs}$ concentration but that the secondary ${ }^{90} \mathrm{Sr}$ peak at about $40 \mathrm{~cm}$ occurs at a sediment depth where the ${ }^{137} \mathrm{Cs}$ profile is relatively uniform. A sediment accumulation rate of $2.7 \mathrm{~cm} /$ year (Fig. 10) suggests that another substantial release of ${ }^{90} \mathrm{Sr}$ occurred on the ORR during 1972-1973.

The total amount of ${ }^{137} \mathrm{Cs}$ that has accumulated at the core 567.5 site can be estimated by summing the vertical distribution of ${ }^{137} \mathrm{Cs}$ over the diameter of the sediment core. This calculation indicates that about $1580 \mathrm{pCi} / \mathrm{cm}^{2}$, or $15,800 \mathrm{mCi} / \mathrm{km}^{2}$, has accumulated at the mouth of the Clinch River into Watts Bar Reservoir. This inventory is about 165 times 


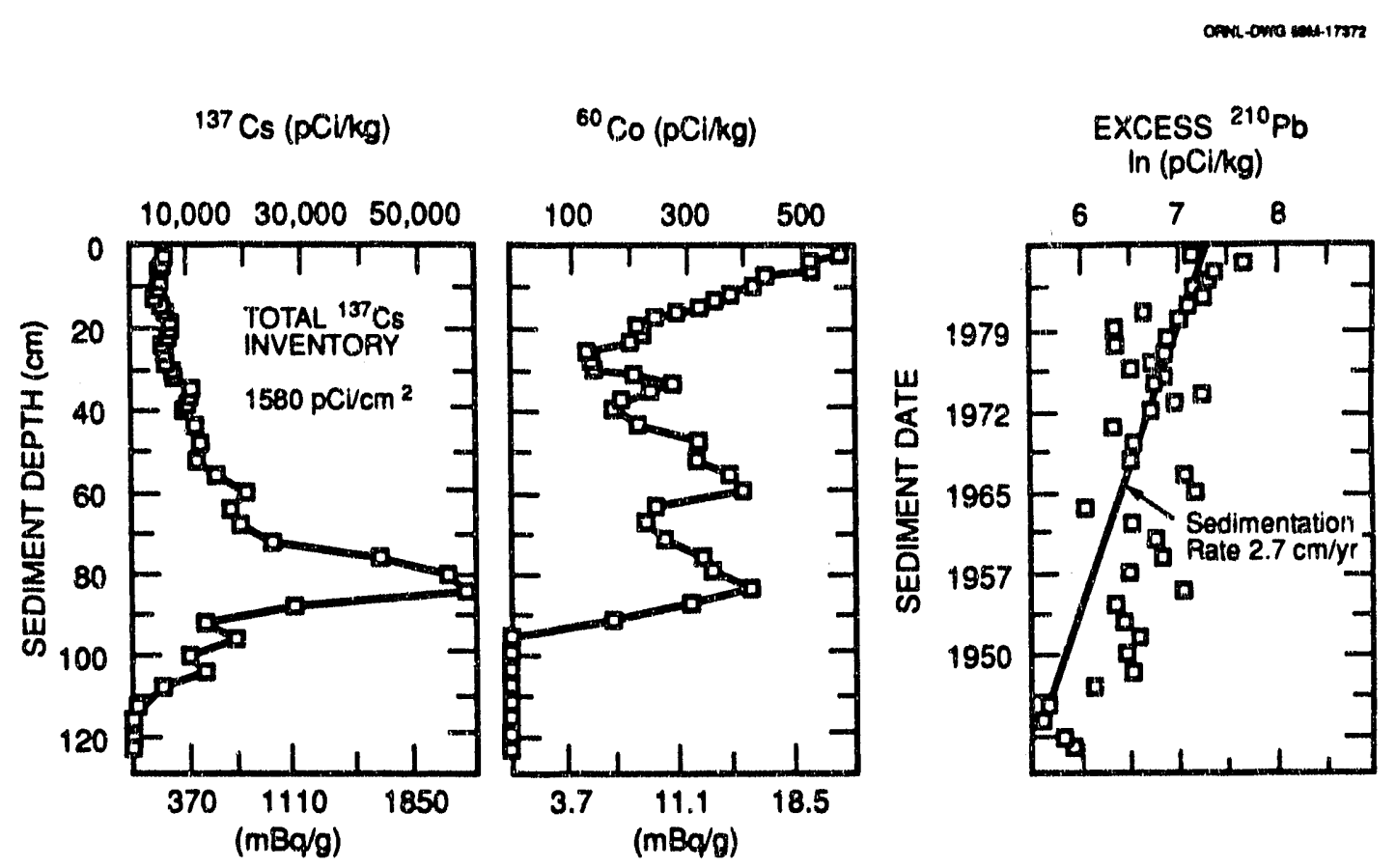

Fig. 10. Vertical profiles for ${ }^{137} \mathrm{Cs},{ }^{\infty} \mathrm{Co}$, and excess ${ }^{20} \mathrm{~Pb}$ in sediment core 567.5. The line drawn through the ${ }^{210} \mathrm{~Pb}$ data has a slope corresponding to the sedimentation rate determined by the ${ }^{137} \mathrm{Cs}$ peak

greater than the ${ }^{137} \mathrm{Cs}$ inventory expected from global fallout (about $95 \mathrm{mCi} / \mathrm{km}^{2}$ ) in association with the atmospheric testing of nuclear weapons in the mid-1960s.

For comparison, the vertical profile and inventory of ${ }^{137} \mathrm{Cs}$ in a sediment core collected from Norris Reservoir are presented in Fig. 12 Norris is the reservoir farthest upstream on the Clinch River and drains a relatively pristine area of the Cumberland Mountains. The rate of sediment accumulation (as determined from the excess ${ }^{210} \mathrm{~Pb}$ profile for this core) is $1.8 \mathrm{~cm} / y e a r$. Although the vertical ${ }^{137} \mathrm{Cs}$ profile in this core also exhibits a peak, it occurs at a sediment depth that corresponds to the $1962-1964$ maximum in fallout ${ }^{137} \mathrm{Cs}$ delivery (Olsen et al. 1989a). The total inventory of ${ }^{137} \mathrm{Cs}$ in this core is about $49 \mathrm{pCi} / \mathrm{cm}^{2}$, or $490 \mathrm{mCi} / \mathrm{km}^{2}$, which is about five times greater than the inventory expected from global fallout. The inventory of excess ${ }^{210} \mathrm{~Pb}$ in this Norris sediment core is also about five times greater than the level expected from its atmospheric flux (Olsen et al. 1989a). Consequently, it is suspected that sedirnents eroded from other areas of the upstream Clinch River (which contain fallout ${ }^{137} \mathrm{Cs}$ and excess ${ }^{210} \mathrm{~Pb}$ ) are being focused during accumulation at this site. Even with sediment scusing, it is apparent that the inventory of ${ }^{137} \mathrm{Cs}$ in Watts Bar Reservoir is at least 30 times greater than the inventory expected from atmospheric fallout.

The total burden of ${ }^{137} \mathrm{Cs}$ in Watts Bar Reservoir sediments was estimated by measuring the inventory of ${ }^{137} \mathrm{Cs}$ in each sediment core (Appendix A) and integrating these data over the entire reservoir using the ARC:INFO Geographic Information System (GIS). Logistically, 


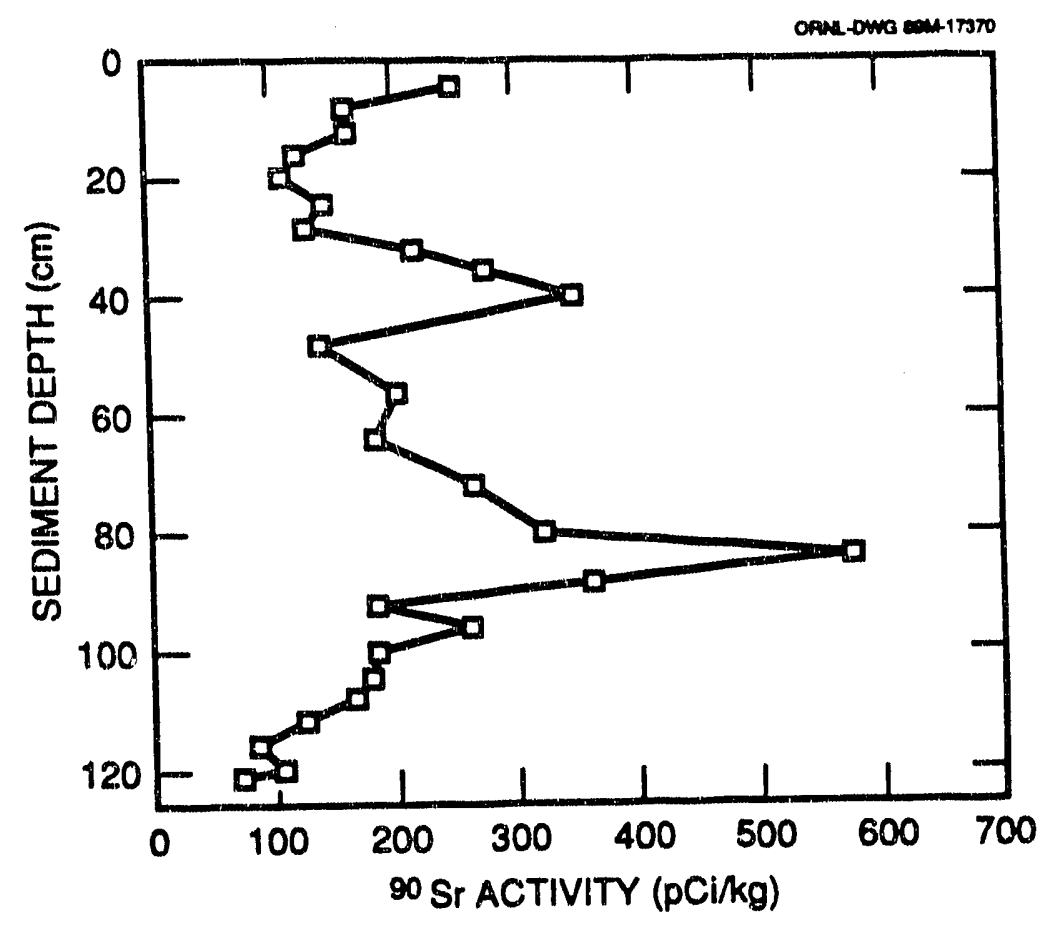

Fig. 11. Vertical distribution of "Sr in sediment core 567.5.

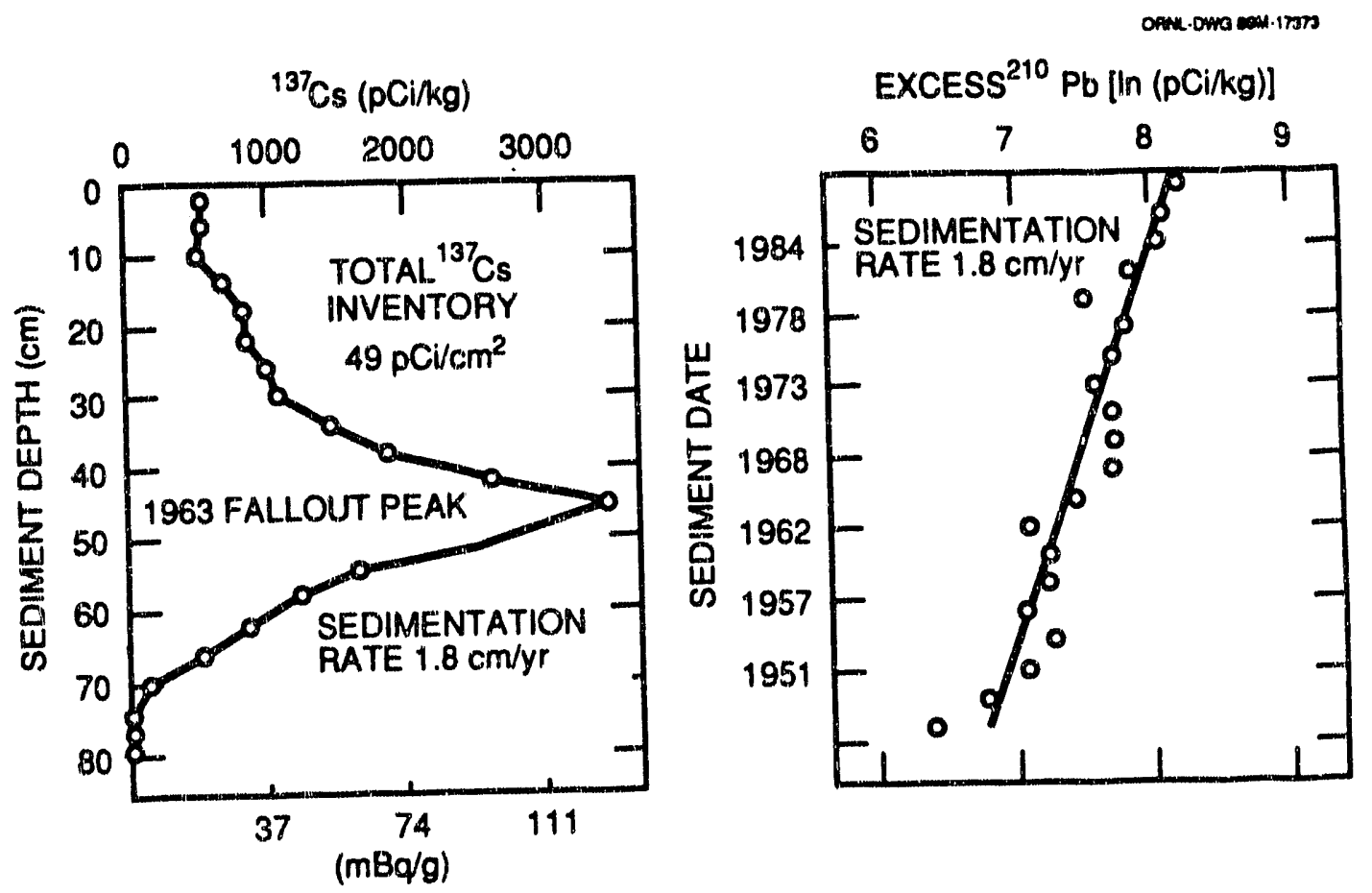

Fig. 12 Vertical profiles for ${ }^{27} \mathrm{Cs}$ and cxcess ${ }^{210} \mathrm{~Pb}$ in the sediments of Norris Reservoir. 
the reservoir surface area (from the city of Kingston to Watts Bar Dam) was subdivided into polygons (Fig. 13) on the basis of (1) proximity to the mouth of the Clinch River, (2) sedimentary characteristics, and (3) the ${ }^{137} \mathrm{Cs}$ concentration in surface-sediment samples (Appendix A). A ${ }^{137} \mathrm{Cs}$ inventory was then calculated for each polygonal area (Fig. 14). In areas where no sediment cores were collected, the ${ }^{137} \mathrm{Cs}$ inventory was estimated as an average calculated from the inventories for cores collected within the same vicinity and with the same sedimentary characteristics.

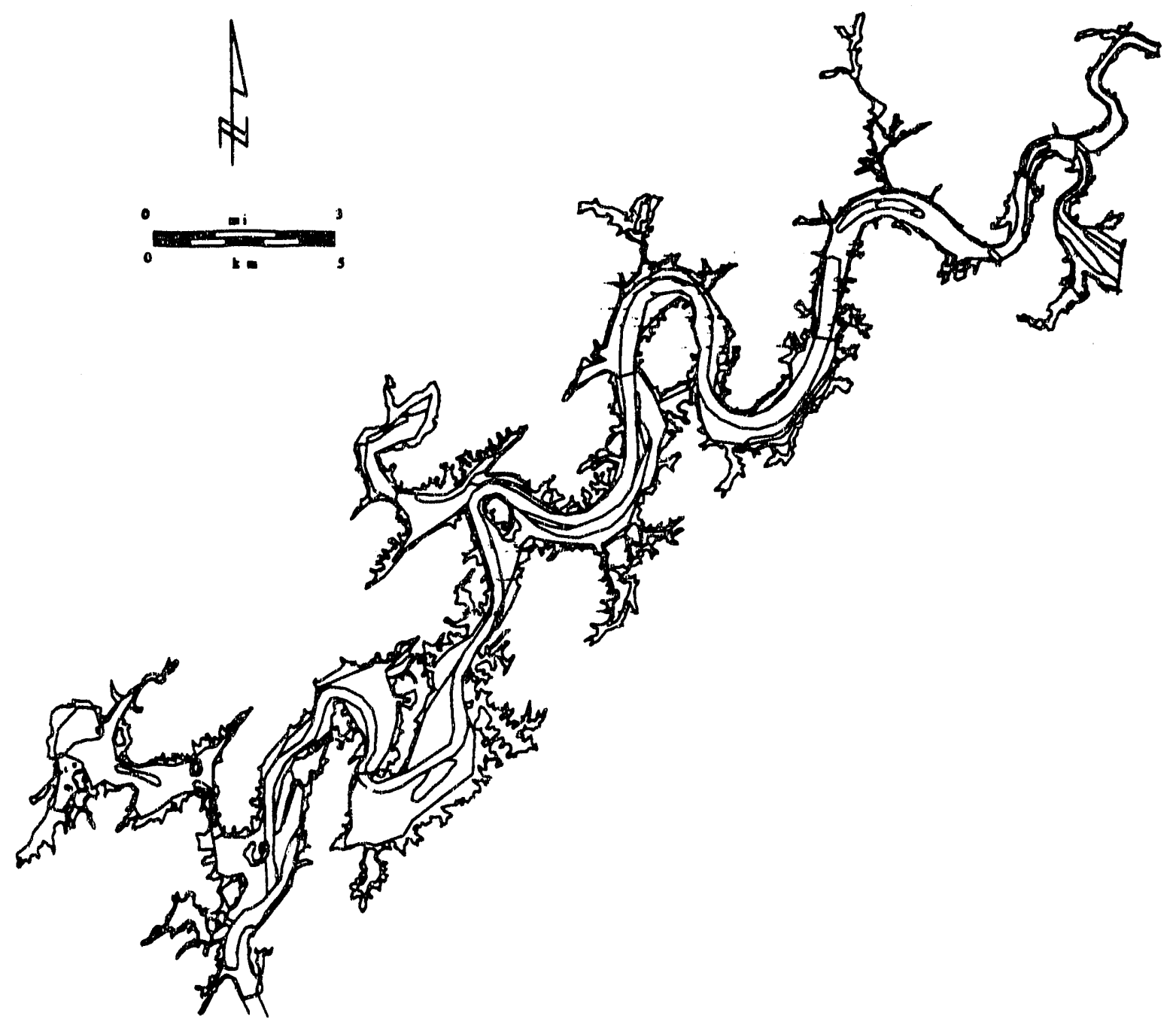

Fig. 13. Map of Watts Bar Reservoir illustrating the GIS polygonal areas that were used for integrating the sediment core data over the entire reservoir. 


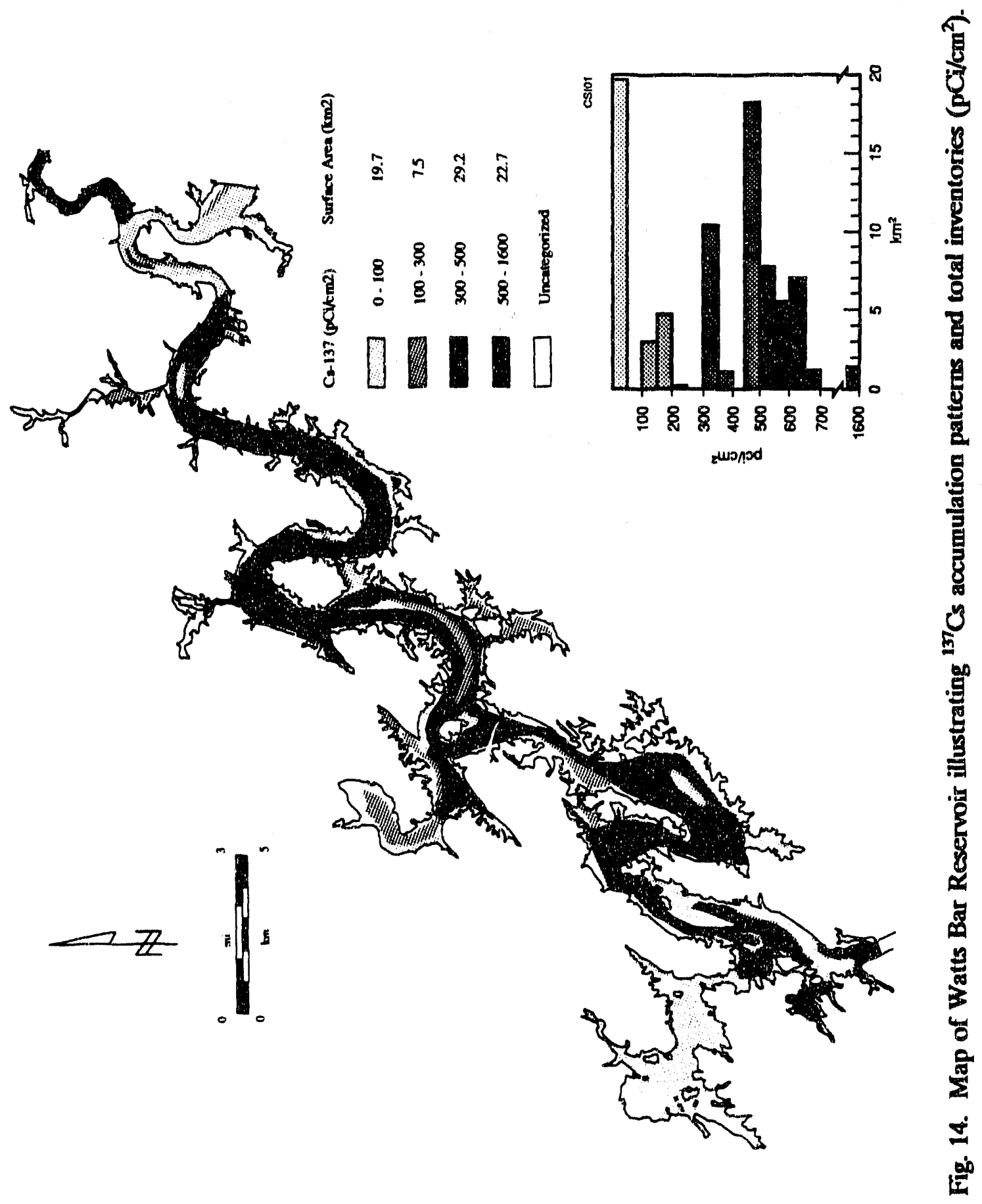


The three main points illustrated in Fig. 14 are that

1. the highest ${ }^{137} \mathrm{Cs}$ inventories occur along the old Clinch River and Tennessee River channels (deepest portions of the reservoir), where the impoundment of water has reduced currents and induced rapid accumulation of sediment and particle-associated contaminants;

2. scouring and little or no ${ }^{137} \mathrm{Cs}$ accumulation is occurring in areas where river currents are still strong and relatively unaffected by Watts Bar Dam; and

3. the sediments in marginal coves appear to contain relatively minor amounts of ${ }^{137} \mathrm{Cs}$ accumulation, suggesting local sediment sources rather than particles derived from the Clinch or Tennessee rivers.

Although total ${ }^{137} \mathrm{Cs}$ inventories are greatest along the impounded river channel, ${ }^{137} \mathrm{Cs}$ concentrations and inventories in near-surface (0- to 50-cm and $0-$ to $16-\mathrm{cm})$ sediments appear to be highest along the shallower channel margins (Figs. 15 and 16). This is because peak ${ }^{137} \mathrm{Cs}$ concentrations occur closer to the sediment surface in areas affected by relatively lower rates of sediment accumulation (Figs. 9 and 15). This has important environmental and ecological implications because (1) epibenthic fauna are generally confined to the top $16 \mathrm{~cm}$ of sediment (biologically active layer) and (2) game fish are often caught in shallower marginal habitats. The risk to human health of these peak ${ }^{137} \mathrm{Cs}$ concentrations was preliminarily evaluated by Hoffman et al. (1991), who found that there was no imminent risk to human health, as long as the sediments remained in the reservoir without being disturbed.

The total ${ }^{137} \mathrm{Cs}$ inventory calculated from the sum of the polygons was $304 \mathrm{Ci}(1.12 \times$ $10^{13} \mathrm{~Bq}$ ). Because a decay-corrected total of $335 \mathrm{Ci}$ of ${ }^{137} \mathrm{Cs}$ has been released into the Clinch River via WOL between 1949 and 1986 , it appears that about $91 \%$ of the ${ }^{137} \mathrm{Cs}$ released from WOD has been trapped within the sediments of Watts Bar Reservoir. The remaining $9 \%$ may reflect error in the estimate, unmonitored discharges before 1949 , or uncertainty in the ${ }^{137} \mathrm{Cs}$ release history, or it may indicate the relative amount of ${ }^{137} \mathrm{Cs}$ retained in floodplain areas or transported downstream past Watts Bar Dam.

\section{MERCURY AND ${ }^{137} \mathrm{CS}$ CORREILATIONS}

A comparison of the aquatic discharge histories of ${ }^{137} \mathrm{Cs}$ from ORNL's WOL and inorganic $\mathrm{Hg}$ from the Y-12 Plant (Fig. 2) shows the near coincidence of the peak release of ${ }^{137} \mathrm{Cs}$ in 1956 with that of $\mathrm{Hg}$ in 1957-1958 and sharp declines in both releases after 1959. Because of this near coincidence in peak release years and because of the high chemical affinity of both $\mathrm{Hg}$ and ${ }^{137} \mathrm{Cs}$ for particulate matter, the vertical profiles of these two contaminants in sediment cores collected throughout Watts Bar Reservoir were strongly correlated (Fig. 17).

This relationship is illustrated in Fig. 18, and the resultant coefficient of determination $\left(r^{2}\right)$ is 0.87 . This $r^{2}$ value indicates that $87 \%$ of the variation in the mercury data can be accounted for by the ${ }^{137} \mathrm{Cs}$ data via a linear-regression model. The corresponding correlation coefficient (r) for the $\mathrm{Hg}^{137} \mathrm{Cs}$ relationship is 0.93 . The amount of $\mathrm{Hg}$ in a sediment sample from Watts Bar Reservoir can be estimated fairly accurately by multiplying the ${ }^{137} \mathrm{Cs}$ inventory by 0.25 (Fig. 18). 


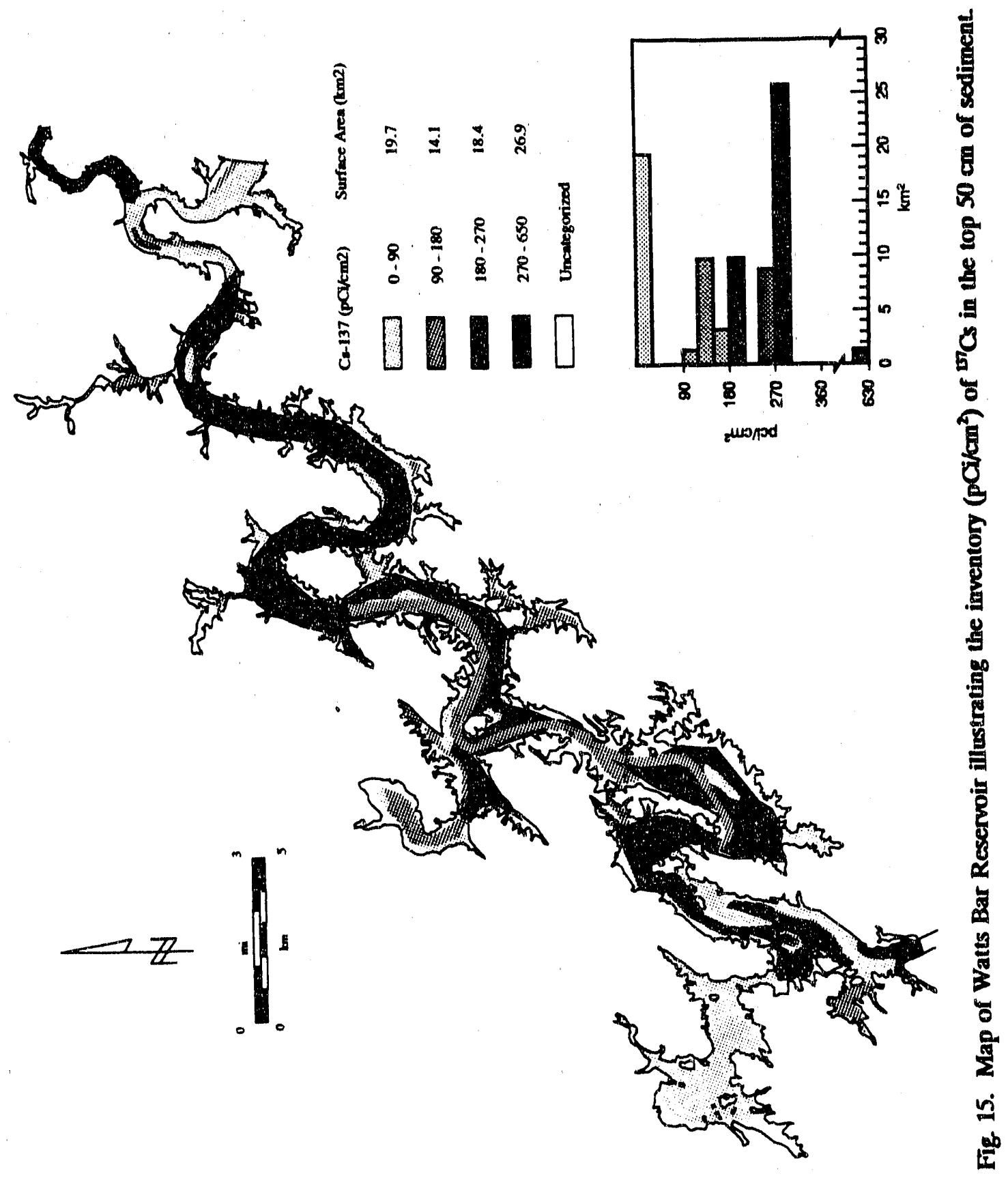




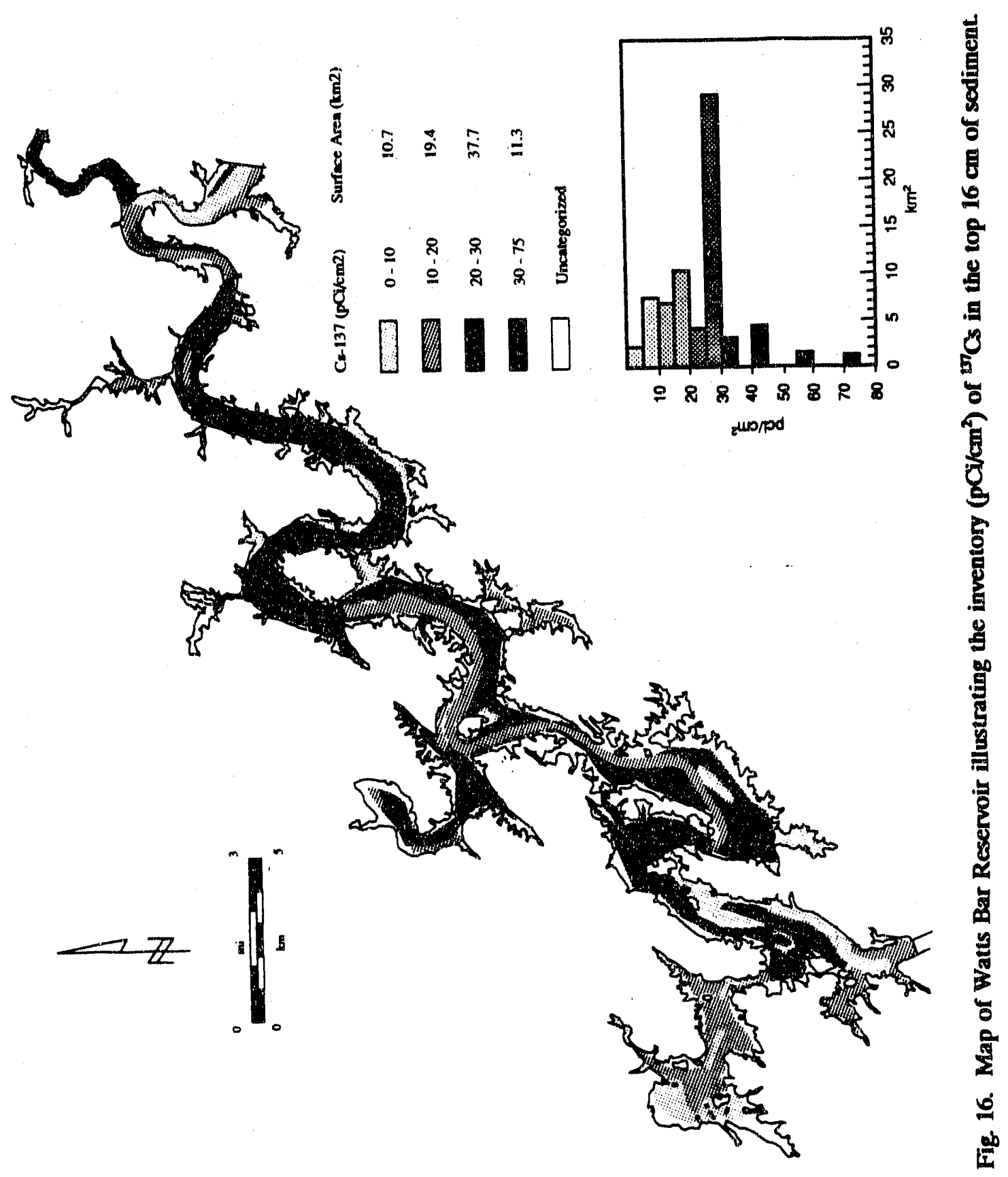



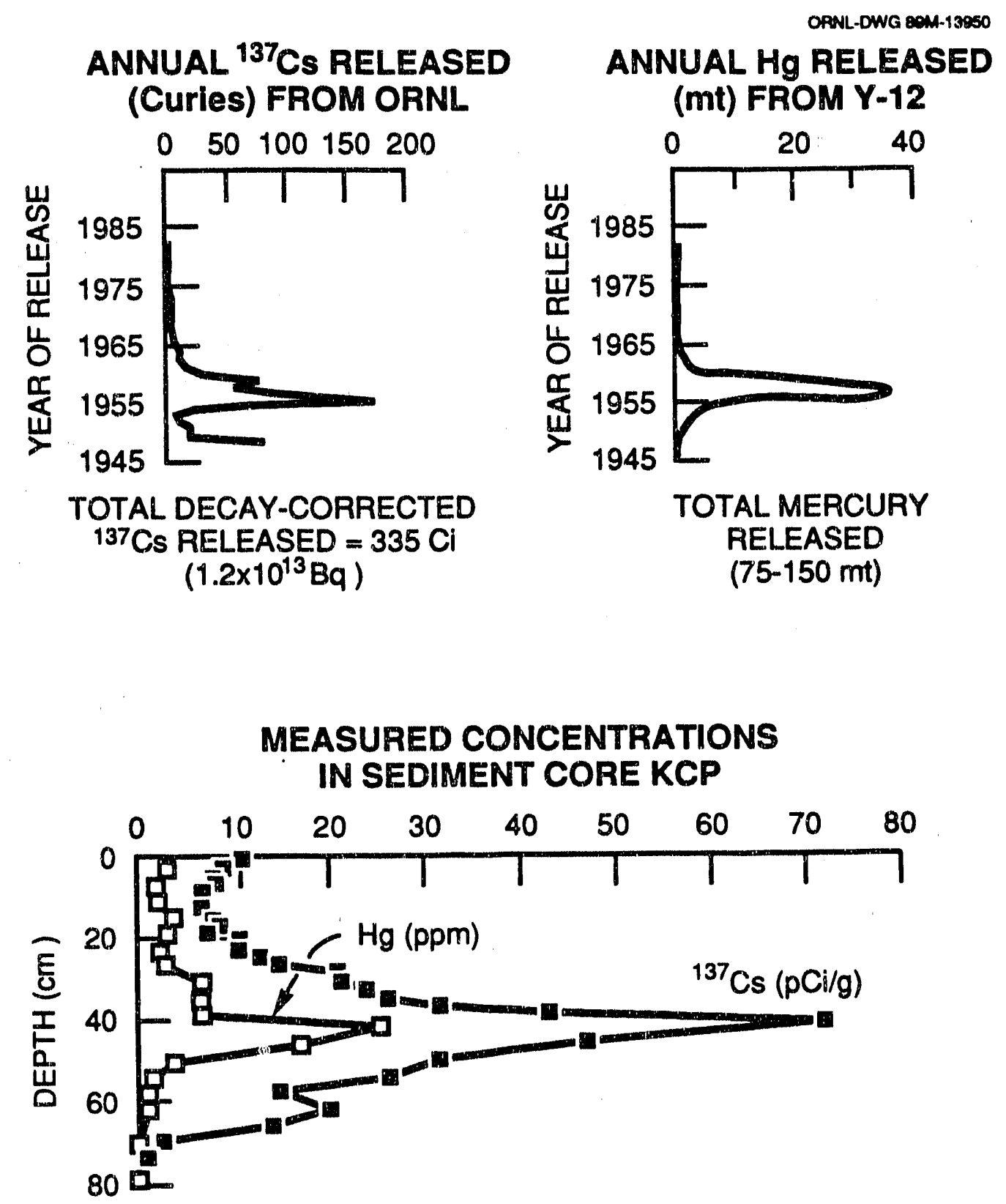

Fig. 17. The history of ${ }^{137} \mathrm{Cs}$ releases from $\mathrm{ORNL}$ and $\mathrm{Hg}$ releases from $\mathrm{Y}-12$ compared with the vertical distribution of ${ }^{137} \mathrm{Cs}$ and $\mathrm{Fig}$ in the sediments of core $\mathrm{XCP}$. 


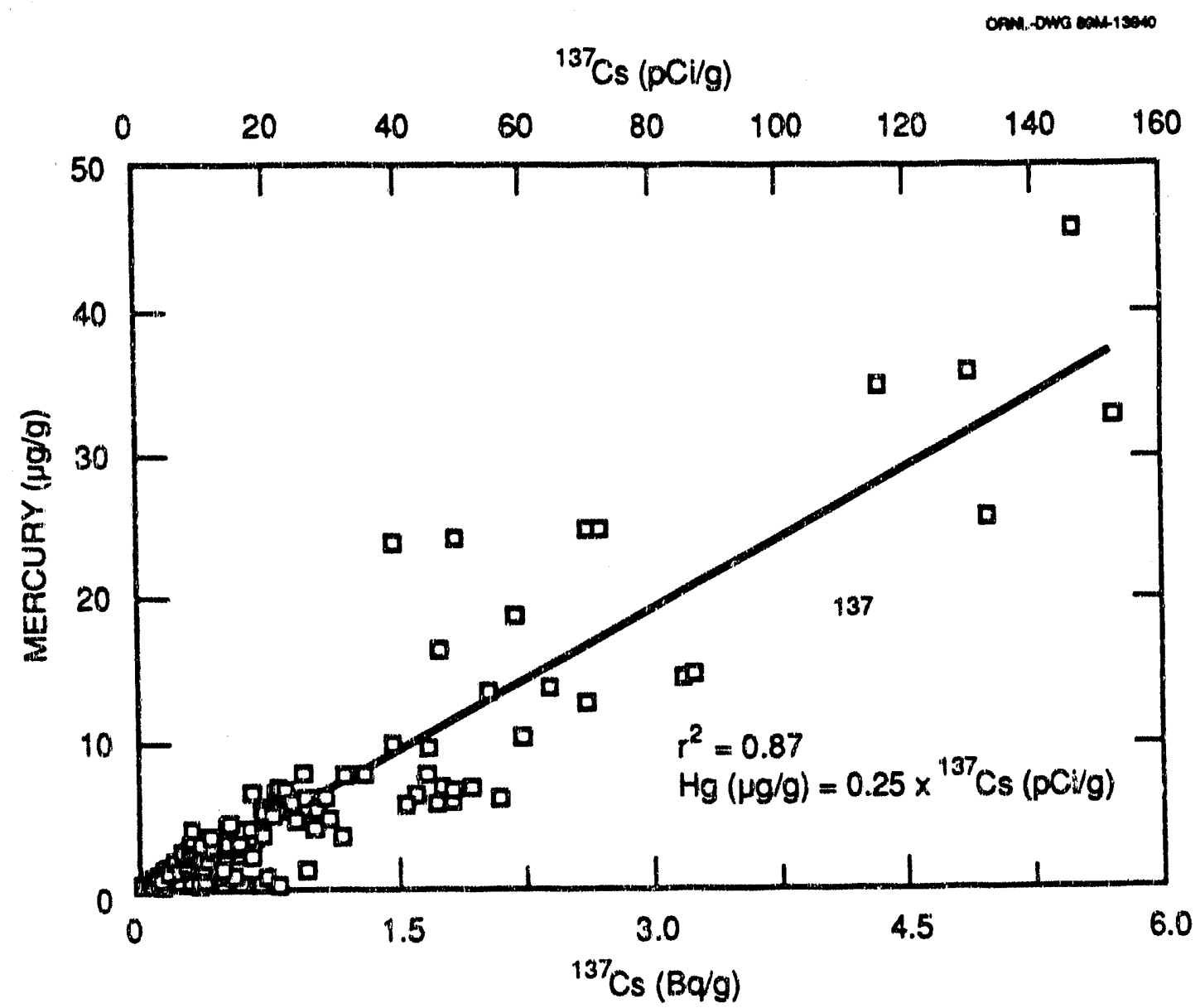

Fig. 18. Wlustration of the relationship between the corcentration of ${ }^{27} \mathrm{C} s$ and the concentration of $\mathrm{Hg}$ in the sodiments of Watts Bar Reservoir.

Using information on the concentration and distribution of ${ }^{13 \%} \mathrm{Cs}$ as an indicator of the concentration and distribution of $\mathrm{Hg}$, we have generated GIS maps that illustrate total $\mathrm{Hg}$ inventories (Fig. 19) and concentrations (Figs. 20 and 21) in the sediments of Watts Bar Reservoir. In addition, we estimate that about 76 metric tons of $\mathrm{Hg}$ has accumulated within the reservoir sediments.

$$
\mathrm{Hg}(\mu \mathrm{g} / \mathrm{g})=0.25 \times{ }^{137} \mathrm{Cs}(\mathrm{pCi} / \mathrm{g})
$$

or

$$
\begin{gathered}
\mathrm{Hg}(\mathrm{mt})=0.25 \times{ }^{137} \mathrm{Cs}(\mathrm{Ci}) \\
\mathrm{Hg}(\mathrm{mt})=0.25 \times 304 \mathrm{Ci} \\
\mathrm{Hg}(\mathrm{mt})=76.0
\end{gathered}
$$

Because of the skewed distribution of both the ${ }^{137} \mathrm{Cs}$ and $\mathrm{Hg}$ data, a log-log transformation was also performed and a linear model fit to the transformed data. The functional form of the model is $\left.\mathrm{Hg}=(a), \mathrm{Cs}^{b}\right)$, where $a$ is the intercept and $b$ is the slope. An analysis of 


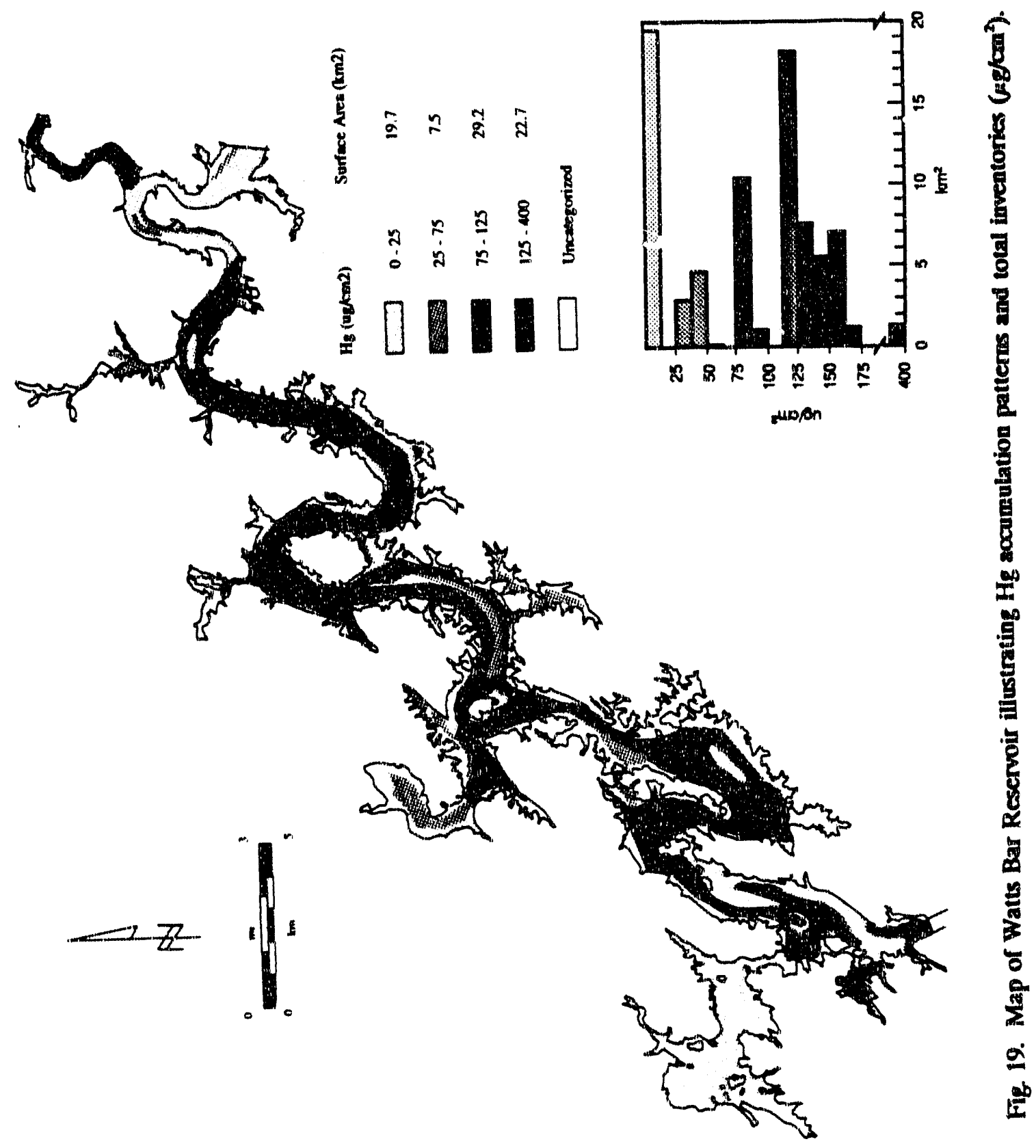




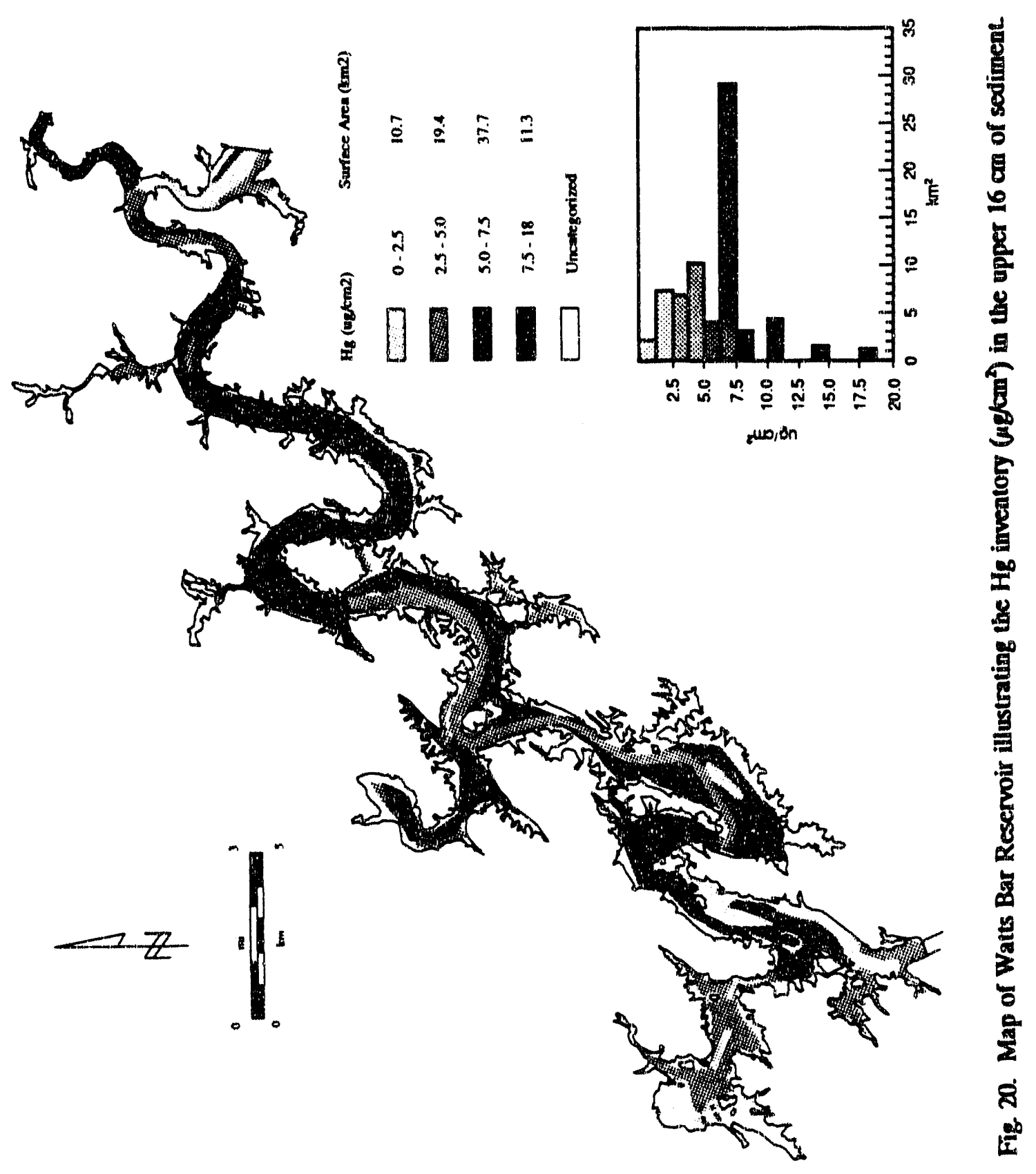




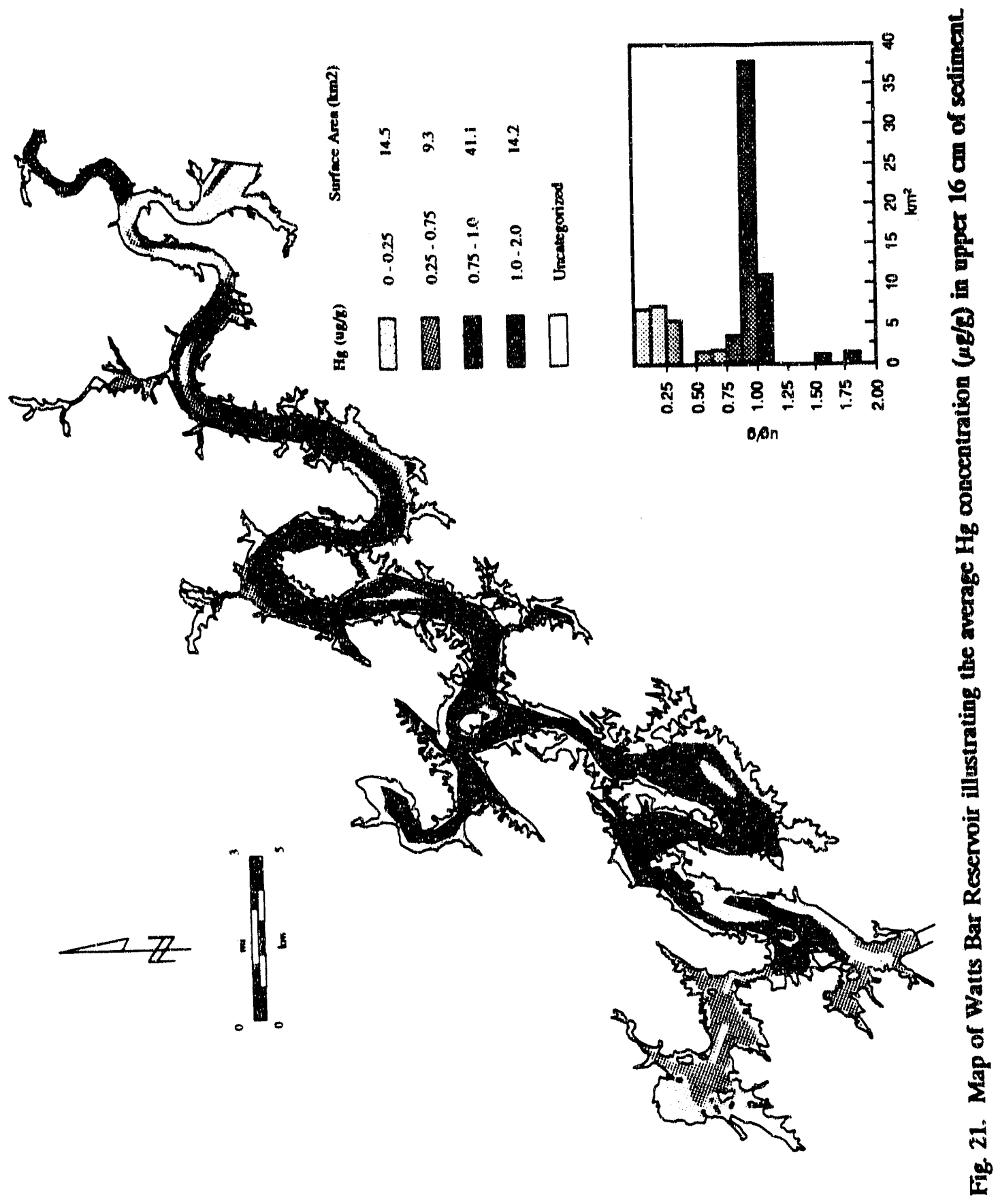


covariance revealed that a separate model was needed for the Clinch River and Watts Bar cores. For both the Clinch River and Watts Bar data, we found that $87 \%\left(r^{2}=0.87\right)$ of the variation in the mercury data can be explained by the ${ }^{137} \mathrm{Cs}$ data. The model parameter estimates determined in this analysis are

\begin{tabular}{|c|c|c|}
\hline Location & $a$ & $b$ \\
\hline Clinch River & 0.335 & 0.884 \\
\hline Watts Bar & 0.265 & 0.889 \\
\hline
\end{tabular}

Based on these models, we estimate that 62 metric tons of mercury is retained in the system. This model together with the linear model described above provides an estimate on the range of total mercury in Watts Bar.

\section{HISTORICAL CONCENTRATIONS OF DISSOLVED MERCURY IN WATTS BAR RESERVOIR}

Because sorption onto suspended particles and sediments is the principal mechanism by which many chemicaily reactive contaminants (such as ${ }^{137} \mathrm{Cs}$ and $\mathrm{Hg}$ ) are removed from ayuatic systems, the history of contamination in Watts Bar Reservoir has been recorded in the sediments (Fig. 15). Consequently, vertical profiles of ${ }^{137} \mathrm{Cs}$ or $\mathrm{Hg}$ in a chronologically dated sediment core can be used to estimate the age of the sediment and the concentration of $\mathrm{Hg}$ in surface sediments during previous years. In addition, by assuming that the particle-towater distribution of $\mathrm{Hg}$ (about $1 \times 10^{5}$ in Table 5) has been relatively constant at a specific core site throughout the past, we can estimate past levels of dissolved $\mathrm{Hg}$ from the dated levels of $\mathrm{Hg}$ in the sediment cores.

Estimates for the historical concentrations of dissolved $\mathrm{Hg}$ near the mouth of the Clinch River and in Watts Bar Reservoir are presented in Tables 6 and 7. It is evident from the data in Table 7 that the levels of dissolved $\mathrm{Hg}(0.005 \mu \mathrm{g} / \mathrm{L})$ estimated from the $\mathrm{Hg}$ concentration in the dated surface sediments are similar to the dissolved levels measured in the water column ( $0.004 \mathrm{ppb}$ in Table 5). At the mouth of the Clinch River, however, before its confluence with the Tennessee River, estimated dissolved $\mathrm{Hg}$ concentrations are about three times higher. The highest predicted dissolved $\mathrm{Hg}$ levels $(0.224 \mathrm{ppb}$, or $\mu \mathrm{g} / \mathrm{L})$ occurred between 1957 and 1959 at this site (Table 6). At the mouth of White Creek near the midsection of Watts Bar Reservoir (Fig. 1), the highest predicted dissolved $\mathrm{Hg}$ concentrations were about $0.06 \mu \mathrm{g} / \mathrm{L}$ (Table 7), and these levels also occurred during 1957-1958. These $\mathrm{Hg}$ concentrations are similar to those measured elsewhere in the Clinch River/Watts Bar Reservoir system and, according to Hoffman et al. (1991), do not pose an imminent risk to human health.

This information is critical for assessing the environmental and health risks associated with the past discharges of contaminants into aquatic systems. Historical estimates for dissolved contaminants with additional information on contaminant bioaccumulation in organisms are needed to predict contaminant levels in fish caught and consumed in prior years. Once particle-to-water distributions and vertical sedimentary profiles for other contaminants of concern are measured in Watts Bar Reservoir, it will be possible to obtain relatively accurate estimates for their past concentrations in drinking water or edible tissues. 
Table 6. Watts Bar sediment core 567.5 (August 22, 1986)

\begin{tabular}{|c|c|c|c|c|c|}
\hline $\begin{array}{l}\text { Sediment } \\
\text { depth } \\
(\mathrm{cm})\end{array}$ & $\begin{array}{c}\text { Dry } \\
\text { weight } \\
(g)\end{array}$ & $\begin{array}{c}{ }^{137} \mathrm{Cs} \\
\text { sediment } \\
(\mathrm{pCi} / \mathrm{g} \pm 1 \sigma)\end{array}$ & $\begin{array}{c}\mathrm{Hg} \\
\text { sediment } \\
(\mu \mathrm{g} / \mathrm{g})\end{array}$ & $\begin{array}{c}\mathrm{Hg} \\
\text { dissolved }^{a} \\
(\mu \mathrm{g} / \mathrm{L})\end{array}$ & $\begin{array}{l}\text { Historical } \\
\text { time period } \\
\text { (years) }\end{array}$ \\
\hline $0-4$ & 72.58 & $5.26 \pm 0.06$ & 1.52 & 0.015 & 1986 \\
\hline $4-8$ & 119.62 & $5.68 \pm 0.07$ & 1.36 & 0.014 & 1984-1985 \\
\hline 8-12 & 127.51 & $5.06 \pm 0.08$ & 1.77 & 0.018 & 1983 \\
\hline $12-16$ & 140.85 & $6.05 \pm 0.19$ & 2.42 & 0.024 & $1981-1982$ \\
\hline $16-20$ & 147.80 & $7.39 \pm 0.07$ & 3.16 & 0.032 & 1980 \\
\hline $20-24$ & 144.13 & $6.51 \pm 0.06$ & 2.32 & 0.023 & 1978-1979 \\
\hline $24-28$ & 138.34 & $6.61 \pm 0.06$ & 2.32 & 0.023 & 1977 \\
\hline $28-32$ & 109.97 & $7.85 \pm 0.06$ & 3.33 & 0.033 & $1975-1976$ \\
\hline $32-36$ & 101.34 & $11.01 \pm 0.09$ & 3.44 & 0.034 & 1974 \\
\hline $36-40$ & 133.20 & $9.81 \pm 0.06$ & 2.98 & 0.030 & $1972-1973$ \\
\hline $40-48$ & 144.17 & $12.03 \pm 0.24$ & 2.91 & 0.029 & 1969-1971 \\
\hline $48-56$ & 149.98 & $13.56 \pm 0.11$ & 4.12 & 0.041 & $1966-1968$ \\
\hline $56-64$ & 161.15 & $19.02 \pm 0.15$ & 5.10 & 0.051 & 1963-1965 \\
\hline $64-72$ & 156.36 & $22.24 \pm 0.11$ & 6.80 & 0.068 & $1960-1962$ \\
\hline $72-80$ & 145.92 & $49.08 \pm 0.21$ & 24.40 & 0.244 & 1957-1959 \\
\hline $80-84$ & 70.62 & $58.36 \pm 0.17$ & 19.00 & 0.190 & $1955-1956$ \\
\hline $84-88$ & 78.68 & $28.66 \pm 0.11$ & 6.31 & 0.063 & $1952-1954$ \\
\hline $88-92$ & 81.22 & $13.01 \pm 0.07$ & 1.24 & 0.012 & $1950-1951$ \\
\hline $92-96$ & 79.15 & $18.59 \pm 0.08$ & 0.36 & 0.004 & 1948-1949 \\
\hline $96-100$ & 77.05 & $10.64 \pm 0.07$ & 0.35 & 0.003 & $1946-1947$ \\
\hline $100-104$ & 76.68 & $13.11 \pm 0.07$ & 0.31 & 0.003 & \\
\hline $104-108$ & 75.71 & $5.84 \pm 0.05$ & 0.34 & 0.003 & \\
\hline $108-112$ & 81.48 & $0.87 \pm 0.02$ & 0.12 & 0.001 & \\
\hline $112-116$ & 118.11 & $0.25 \pm 0.03$ & $\left.0 . r^{\prime \prime}\right)$ & 0.001 & \\
\hline $116-120$ & 119.10 & $0.27 \pm 0.05$ & 0.05 & 0.001 & \\
\hline $120-122$ & 125.07 & $0.00 \pm 0.00$ & & & \\
\hline
\end{tabular}

${ }^{a}$ Estimated using a particle-to-water distribution ratio of $1 \times 10^{s}$.

${ }^{b}$ Estimated using a sediment accumulation rate of $1.4 \mathrm{~cm} / \mathrm{year}$. 
Table 7. Watts Bar sediment core 8-2-3 (October 17, 1986)

\begin{tabular}{cccccc}
\hline $\begin{array}{c}\text { Sediment } \\
\text { depth } \\
(\mathrm{cm})\end{array}$ & $\begin{array}{c}\text { Dry } \\
\text { weight } \\
(\mathrm{g})\end{array}$ & $\begin{array}{c}{ }^{137} \mathrm{Cs} \\
\text { sediment } \\
(\mathrm{pCi} / \mathrm{g} \pm 1 \sigma)\end{array}$ & $\begin{array}{c}\mathrm{Hg} \\
\text { sediment } \\
(\mu \mathrm{g} / \mathrm{g})\end{array}$ & $\begin{array}{c}\mathrm{Hg} \\
\text { dissolved } \\
(\mu \mathrm{g} / \mathrm{L})\end{array}$ & $\begin{array}{c}\text { Historical } \\
\text { time period } \\
\text { (years })\end{array}$ \\
\hline $0-4$ & 13.81 & $3.74 \pm 0.10$ & 0.52 & 0.005 & $1984-1986$ \\
$4-8$ & 18.10 & $3.80 \pm 0.10$ & 0.53 & 0.005 & $1981-1983$ \\
$8-12$ & 26.93 & $3.71 \pm 0.33$ & 0.52 & 0.005 & $1978-1980$ \\
$12-16$ & 31.17 & $4.43 \pm 0.24$ & 0.64 & 0.006 & $1975-1977$ \\
$16-20$ & 31.26 & $4.22 \pm 0.30$ & 0.72 & 0.007 & $1972-1974$ \\
$20-24$ & 32.77 & $5.19 \pm 0.25$ & 0.78 & 0.008 & $1969-1971$ \\
$24-28$ & 37.01 & $5.84 \pm 0.35$ & 1.07 & 0.011 & $1966-19688$ \\
$28-32$ & 39.95 & $11.76 \pm 0.40$ & 1.75 & 0.018 & $1964-1965$ \\
$32-36$ & 43.53 & $15.87 \pm 0.53$ & 2.30 & 0.023 & $1961-1963$ \\
$36-40$ & 44.33 & $24.34 \pm 0.47$ & 4.69 & 0.047 & $1958-1960$ \\
$40-44$ & 42.08 & $27.57 \pm 0.50$ & 5.46 & 0.055 & $1956-1958$ \\
$44-48$ & 42.64 & $9.45 \pm 0.42$ & 1.08 & 0.011 & $1953-1955$ \\
$48-52$ & 46.06 & $10.53 \pm 0.30$ & 0.47 & 0.005 & $1950-1952$ \\
$52-56$ & 48.91 & $11.67 \pm 0.41$ & 0.29 & 0.003 & $1947-1949$ \\
$56-60$ & 63.41 & $3.33 \pm 0.19$ & 0.14 & 0.001 & $1944-1946$ \\
$60-62$ & 53.50 & $0.29 \pm 0.07$ & 0.06 & 0.001 & \\
\hline
\end{tabular}

${ }^{a}$ Estimated using a particle-to-water distribution ratio of $1 \times 10^{5}$.

${ }^{b}$ Estimated using a sediment accumulation rate of $1.4 \mathrm{~cm} / \mathrm{year}$. 


\section{SUMMARY}

Operations and waste disposal activities on the DOE ORR have introduced ${ }^{137} \mathrm{Cs}$ and $\mathrm{Hg}$ into local streams that ultimately drain into the Clinch River and Tennessee River systems. Previous work has shown that (1) the highest discharges for both ${ }^{137} \mathrm{Cs}$ and $\mathrm{Hg}$ occurred during the mid-1950s; (2) contaminants introduced into the Clinch River have not remained there in either the bottom sediments or in the biota but instead have been flushed downstream; and (3) Watts Bar Reservoir (like other reservoirs on river systems) serves as a very efficient trap for riverborne particles, nutrients, and contaminants and is therefore a site of rapid sediment and contaminant accumulation.

To address the need for characterizing the nature and extent of contamination in Watts Bar Reservoir, we have measured the vertical distribution of ${ }^{137} \mathrm{Cs}$ in over 60 sediment cores and the concentration of ${ }^{137} \mathrm{Cs}$ in more than 190 surface-sediment samples. This work represents the initial scoping phase for the Clinch River RCRA Facility Investigation and uses the distribution of ${ }^{137} \mathrm{Cs}$ to identify contaminant accumulation patterns and potential problem, or "hot-spot," areas with regard to environmental hazard or human health. Radiocesium was chosen for this scoping effort because (1) its history of release into the Clinch River is reasonable well documented, (2) it is easy and inexpensive to measure by gamma spectrometry, and (3) it is rapidly sorbed to particulate matter and thus serves as a costeffective tracer for identifying the transport and accumulation patterns of many other contaminants that are strongly associated with particulate matter, such as $\mathrm{Hg}, \mathrm{Pb}, \mathrm{Pu}, \mathrm{PCBs}$, other metals, and synthetic organic compounds.

The results from this study indicate that both ${ }^{137} \mathrm{Cs}$ and $\mathrm{Hg}$ are strongly associated with particles in Watts Bar Reservoir and have particle-to-water sorption ratios with values about $10^{5}$. Vertical distributions of ${ }^{137} \mathrm{Cs}$ and $\mathrm{Hg}$ in the reservoir sediments are also strongly correlated $\left(r^{2}=0.87\right)$, with both contaminants exhibiting a large subsurface peak coincident with their peak discharge histories. The sediment depth of this subsurface peak and the thickness of contaminated sediment varies with location in the reservoir and depends on the rate of sediment accumulation. A preliminary screening of the contaminants that may contribute to human health and environmental risk (Hoffman et al. 1991; Suter 1991) showed that these ${ }^{137} \mathrm{Cs}$ and $\mathrm{Hg}$ concentrations did not pose an imminent risk. Further study, however, is warranted to determine the need for remediation.

The total accumulation of ${ }^{137} \mathrm{Cs}$ in Watts Bar Reservoir sediments was estimated by measuring the ${ }^{137} \mathrm{Cs}$ inventory in each sedimen core and extrapolating these data spatially with the ARC:INFO software package. These results indicate that about $304 \mathrm{Ci}(1.12 \times$ $10^{13} \mathrm{~Bq}$ ) of ${ }^{137} \mathrm{Cs}$ now reside in the reservoir sediments. Discharge records indicate that a decay-corrected total of about $335 \mathrm{Ci}\left(1.24 \times 10^{13} \mathrm{~Bq}\right)$ of ${ }^{137} \mathrm{Cs}$ was released into the Clinch River system since 1949 . This indicates that almost $91 \%$ of the total ${ }^{137} \mathrm{Cs}$ released has been retained by accumulation in the reservoir sediments.

The strong correlation between the vertical distribution of ${ }^{137} \mathrm{Cs}$ and $\mathrm{Hg}$ in the reservoir sediments was used to estimate that about 76 metric tons of $\mathrm{Hg}$ also reside in the sediments of Watts Bar Reservoir. In addition, the historical record of $\mathrm{Hg}$ accumulation in dated sediment cores was used to document levels of contamination in the reservoir water-column during the past 40 years. The highest level of dissolved $\mathrm{Hg}$ predicted from these data is about $0.224 \mathrm{ppb}$, which occurred between 1957 and 1959. 
This initial scoping study was conducted to provide a preliminary characterization of the spatial extent of ORR-derived contamination in off-site areas, to help design cost-effective sampling strategies in environmental risk and human health assessments, and to identify specific off-site areas requiring more detailed work. Additional characterization of contaminant concentrations and distributions in the sediments, soils, water, and biota of offsite surface water environments will be conducted as part of the Clinch River RCRA Facility Investigation. These additional and more extensive site characterization data will be used to (1) further define the nature and extent of off-site contamination occurring downstream of the ORR, (2) estimate potential risks to human health and to the environment that may be associated with the occurrence of off-site contaminants, and (3) evaluate the need for remediation activities designed to reduce human-health and environmental risks. 


\section{REFERENCES}

Ashwood, T. L., C. R. Olsen, I. L. Larsen, and P. D. Lowry. 1986. Sediment Contamination in Streams Surrounding the Oak Ridge Gaseous Diffusion Plant. ORNL/TM-9791.

Cottrell, W. D. 1959. Radioactivity in Silt of the Clincis and Tennessee Rivers. ORNL-2847.

Cowser, K. E., W. S. Snyder, C. P. McCammon, C. P. Straub, O. W. Kochtitzky, R. L. Hervin, E. G. Struxness, and R. J. Morgan. 1966. Evaluation of radiation dose to man from radionuclides released to the Clinch River. pp. 639-671 in Disposal of Radioactive Wastes into Seas, Oceans, and Surface Waters, IAEA, Vienna.

Dendy, F. E. 1973. Sediment trap efficiency of small reservoirs. pp. 898-908 in W. C. Ackerman, G. F. White, E. B. Worthington, and J. L. Ivens (eds.), Man-Made Lakes: Their Problems and Environmental Effects, American Geophysical Union Monograph 17, Washington, D.C.

DOE. 1988. Historical Radionuclide Releases from Current DOE Oak Ridge Operations Office Facilities. OR-890. U.S. DOE, Oak Ridge Operations Office, Oak Ridge, Tenn.

Elwood, J. W. 1984. Mercury contamination in Poplar Creek and the Clinch River. ORNL/TM-8893.

Hoffman, F. O., B. G. Blaylock, M. L. Frank, L. A. Hook, E. L. Etnier, and S. S. Talmage. 1991. Preliminary screening of contaminants in the off-site surface water environment downstream of the U.S. Department of Energy Oak Ridge Reservation. ORNL/ER-9. Martin Marietta Energy Systems, Inc., Oak Ridge National Laboratory, Oak Ridge, Tenn.

Jones, C. G., L. E. McNeese, C. L. Baker, L. D. Bates, C. W. Snodgrass, and L. E. Stratton. 1990. Environmental restoration and waste management site-specific plan for the Oak Ridge Reservation. K/ESH-1. Martin Marietta Energy Systems, Inc. Oak Ridge, Tenn.

Kimmel, B. L. and A. Groeger. 1986. Limnological and ecological changes associated with reservoir aging. pp. 103-109 in G. E. Hall and M. J. Van Den Avyle (eds.), Reservoir Fisheries Management: Strategies for the '80s. Reservoir Committee, American Fisheries Society, Bethesda, Md.

Larsen, I. L., and N. H. Cutshall. 1981. Direct determination of ${ }^{7} \mathrm{Be}$ in sediments. Earth Planet. Sci. Lett. 54:379-384.

Loar, J. M., S. M. Adams, G. B. Blaylock, H. L. Boston, M. A. Houston, B. L. Kimmel, J. T. Kitchings, C. R. Olsen, M. J. Ryon, J. G. Smith, G. R. Southworth, A. J. Stewart, B. T. Walton, H. Amano, C. T. Garten, and L. J. Meyers. 1987. First Annual Report on the ORNL Biological Monitoring and Abatement Program, Draft report. ORNL/TM-10399.

Nelson, D. J. 1969. Ecological behavior of radionuclides in the Clinch and Tennessee rivers. pp. 169-187 in Proceedings, Reservoir Fishery Research Symposium, April 5-7, 1967, Athens, Ga.

Oakes, T. W., W. F. Ohnesorge, J. S. Eldridge, T. G. Scott, D. W. Parsons, H. M. Hubbard, O. M. Sealand, K. E. Shank, and L. D. Eyman. 1982. Technical Background Information for the Environmental and Safety Report, Volume 5: The 1977 Clinch River Sediment Survey-Data Presentation. ORNL-5878. 
Ohnesorge, W. F. 1986. Historical Releases of Radioactivity to the Environment from ORNL. ORNL/M-135.

Olsen, C. R., I. L. Larsen, N. H. Cutshall, J. F. Donoghue, O. P. Bricker, and H. J. Simpson, H. J. 1981. Reactor-released radionuclides in Susquehanna River sediments. Nature 294:242-245.

Olsen, C. R., and N. H. Cutshall. 1985. Contaminant levels in the soils and sediments near the proposed Blair Road Bridge construction site. Letter Report to H. Y. Hibbits from T. W. Oakes, Nov. 1, 1985.

Olsen, C. R., I. L. Larsen, P. D. Lowry, R. I. Mclean, and S. L. Domotor. 1989a. Radionuclide Distributions and Sorption Behavior in the Susquehanna.Chesapeake Bay System. Power Plant and Environmental Review PPER-R-12, Maryland Department of Natural Resources, Annapolis, Md.

Olsen, C. R., M. Thein, I. L. Larsen, P. D. Lowry, P. J. Mulholland, N. H. Cutshall, J. T. Byrd, and H. L. Windom. 1989b. Plutonium, lead-210, and stable carbon isotopes in the Savannah estuary: riverborne versus marine sources, Environ. Sci. Techinol. 24:1475-1481.

Parker, F. L., M. A. Churchill, R. W. Andrew, B. J. Frederick, P. H. Carrigan, Jr., J. S. Cragwall, Jr., S. L. Jones, E. G. Struxness, and R. J. Morton. 1966. Dilution, dispersion, and mass transport of radionuclides in the Clinch and Tennessee rivers. pp. 33-55 in Disposal of Radioactive Wastes into Seas, Oceans, and Surface Waters, LAEA, Vienna.

Pickering, R. J., P. H. Carrigan, Jr., T. Tamura, A. A. Abee, J. W. Beverage, and R. W. Andrew, Jr. 1966. Radioactivity in the bottom sediments of the Clinch and Tennessee rivers. pp. 57-88 in Disposal of Radioactive Wastes into Seas, Oceans, and Surface Waters, LAEA, Vienna.

Ritchie, J. C., P. H. Hawks, and J. R. McHenry. 1975. Deposition rates in valleys determined using fallout ${ }^{137}$ Cs. Geol. Soc. Amer. Bull. 80:1128-1130.

Struxness, E. G., P. H. Carrigan, M. A. Churchill, K. E. Cowser, R. J. Morton, D. J. Nelson, and F. L. Parker. 1967. Comprehensive Report of the Clinch River Study. ORNL-4035.

Suter II, G. W. May 1991. Screening Level Risk Assessment for Off-Site Ecological Effects in Surface Waters Downstream from the U.S. Department of Energy Oak Ridge Reservation. ORNL/ER-8. Martin Marietta Energy Systems, Inc., Oak Ridge National Laboratory, Oak Ridge, Tenn.

Turner, R. R., C. R. Olsen, and W. J. Wilcox, Jr. 1985. Environmental Fate of $\mathrm{Hg}$ and ${ }^{137} \mathrm{Cs}$ Discharged from Oak Ridge Facilities. pp. 329-338 in D. D. Hemphill (ed.), Trace Substances in Environmental Health-XIIII. University of Missouri, Columbia, Mo.

TVA 1986. Summany Report for Task 5 of the Instream Contaminant Study, Tennessee Valley Authority, Knoxville, Tenn. 


\section{Appendix A \\ RADIONUCLIDE CONCENTRATIONS IN WATTS BAR RESERVOIR SEDIMENTS}

Note: ${ }^{40} \mathrm{~K}$ concentrations are reported, along with ${ }^{137} \mathrm{Cs}$ concentrations and inventories. ${ }^{40} \mathrm{~K}$ is a naturally occurring, gamma-emitting radionuclide that is present in the environment, particularly in potassium-rich rocks, soils, and sediments. 
Radionuclide concentrations in Watts Bar Reservoir sediments

\begin{tabular}{|c|c|c|c|c|c|}
\hline $\begin{array}{c}\text { Sample } \\
\text { identification }\end{array}$ & $\begin{array}{l}\text { Sample } \\
\text { type" }\end{array}$ & $\begin{array}{l}\text { Depth } \\
\text { (ft) }\end{array}$ & $\begin{array}{c}{ }^{137} \mathrm{Cs} \\
(\mathrm{pCi} / \mathrm{g})\end{array}$ & $\begin{array}{c}{ }^{137} \mathrm{Cs} \\
\left(\mathrm{pCi} / \mathrm{cm}^{2}\right)\end{array}$ & $\begin{array}{c}{ }^{40} \mathrm{~K} \\
(\mathrm{pCi} / \mathrm{g})\end{array}$ \\
\hline C-KCP & soft sed & & $7.76 \pm 0.06$ & 1586 & $14.3 \pm 0.1$ \\
\hline $5-1$ & soft sed & 5 & no sample & & \\
\hline $5-2$ & soft sed & 24 & $5.99 \pm 0.05$ & & $12.4 \pm 0.3$ \\
\hline $5-3$ & soft sed & 50 & $10.65 \pm 0.08$ & & $14.6 \pm 0.4$ \\
\hline $5-4$ & soft sed & 15 & $4.67 \pm 0.04$ & & $12.0 \pm 0.3$ \\
\hline C-567.5 & soft sed & 20 & $6.38 \pm 0.07$ & 1580 & $17.7 \pm 0.6$ \\
\hline WH-1 & sandy mud & 7 & $0.37 \pm 0.01$ & & $10.5 \pm 0.1$ \\
\hline WH-2 & soft sed & 10 & $1.35 \pm 0.02$ & & $14.4 \pm 0.2$ \\
\hline C.GCS & soft sed & 10 & $1.67 \pm 0.04$ & 59 & $14.8 \pm 0.5$ \\
\hline C-7GC & clay mud & 10 & $1.09 \pm 0.02$ & 148 & $14.1 \pm 0.3$ \\
\hline SA-1 & soft sed & 35 & $0.29 \pm 0.02$ & & $13.5 \pm 0.4$ \\
\hline $5 A-2$ & sand & 6 & $0.12 \pm 0.02$ & & $13.2 \pm 0.3$ \\
\hline $5 A-3$ & sand & 9 & $0.24 \pm 0.02$ & & $13.0 \pm 0.4$ \\
\hline $5 A-4$ & sand & 9 & $0.14 \pm 0.02$ & & $12.1 \pm 0.4$ \\
\hline $5 A-5$ & sandy mud & 24 & $0.29 \pm 0.01$ & & $13.2 \pm 0.3$ \\
\hline $5 A-6$ & soft sed & 30 & $0.41 \pm 0.06$ & & $13.6 \pm 0.8$ \\
\hline $5-3-1$ & soil gravel & 6 & $0.67 \pm 0.01$ & & $8.6 \pm 0.2$ \\
\hline $5-3-2$ & sandy mud & 20 & $0.61 \pm 0.01$ & & $12.1 \pm 0.2$ \\
\hline $5-3-3$ & sandy mud & 60 & $1.37 \pm 0.02$ & & $7.6 \pm 0.2$ \\
\hline $5-4-1$ & soft sed & 8 & no sample & & \\
\hline C-5-4-2 & sandy mud & 10 & $1.26 \pm 0.03$ & 18 & $14.0 \pm 0.3$ \\
\hline $5-4.3$ & sandy mud & 30 & $0.45 \pm 0.01$ & & $12.0 \pm 0.1$ \\
\hline $5-4-4$ & sand gravel & 65 & 0.58 上 0.01 & & $7.9 \pm 0.2$ \\
\hline $5-4-5$ & soft sed & 18 & $4.44 \pm 0.04$ & & $21.3 \pm 0.3$ \\
\hline C- $5-4-5$ & soft sed & 18 & $3.48 \pm 0.08$ & 823 & $18.9 \pm 0.6$ \\
\hline $5-5-1$ & sandy mud & 65 & $1.63 \pm 0.02$ & & $11.1 \pm 0.2$ \\
\hline $5-5-2$ & sandy mud & 54 & $2.57 \pm 0.03$ & & $11.5 \pm 0.3$ \\
\hline $5-5-3$ & sand gravel & 18 & $0.11 \pm 0.01$ & & $9.9 \pm 0.2$ \\
\hline $6-1-1$ & sand gravel & 12 & $1.98 \pm 0.03$ & & $13.2 \pm 0.3$ \\
\hline $6-1-2$ & sandy mud & 16 & $2.78 \pm 0.04$ & & $13.5 \pm 0.3$ \\
\hline $6-1-3$ & sand gravel & 6 & no sample & & \\
\hline $6-1-3 A$ & sandy mud & 12 & $2.64 \pm 0.04$ & & $12.9 \pm 0.3$ \\
\hline $6-1-4$ & soft sed & 60 & $2.66 \pm 0.05$ & & $11.6 \pm 0.4$ \\
\hline $6-1.5$ & soft sed & 45 & $2.61 \pm 0.04$ & & $13.3 \pm 0.3$ \\
\hline $6-1-6$ & soft sed & 12 & $3.57 \pm 0.04$ & & $13.4 \pm 0.3$ \\
\hline C- $-6-1-6$ & soft sed & 12 & $3.89 \pm 0.06$ & 406 & $14.7 \pm 0.5$ \\
\hline $\mathrm{CCl}$ & sandy mud & 20 & $0.90 \pm 0.03$ & & $18.5 \pm 0.4$ \\
\hline $\mathrm{C}-\mathrm{CCl}$ & sandy mud & 20 & $1.15 \pm 0.10$ & 91 & $12.0 \pm 1.2$ \\
\hline $\mathrm{CC} 2$ & sandy mud & 20 & $0.87 \pm 0.02$ & & $20.3 \pm 0.3$ \\
\hline $\mathrm{CC3}$ & sandy mud & 28 & $1.02 \pm 0.03$ & & $10.7 \pm 0.3$ \\
\hline C. $\mathrm{CC} 3$ & sandy mud & 21 & $0.86 \pm 0.04$ & 109 & $13.3 \pm 0.5$ \\
\hline C-6-2-1 & soft sed & 18 & $3.04 \pm 0.06$ & 711 & $14.3 \pm 0.6$ \\
\hline
\end{tabular}


Radionuclide concentrations (continued)

\begin{tabular}{|c|c|c|c|c|c|}
\hline $\begin{array}{c}\text { Sample } \\
\text { identification }\end{array}$ & $\begin{array}{c}\text { Sample } \\
\text { type }\end{array}$ & $\begin{array}{l}\text { Depth } \\
\text { (ft) }\end{array}$ & $\begin{array}{l}{ }^{137} \mathrm{Cs} \\
(\mathrm{pCi} / \mathrm{g})\end{array}$ & $\begin{array}{c}{ }^{1377} \mathrm{Cs} \\
\left(\mathrm{pCi} / \mathrm{cm}^{2}\right)\end{array}$ & ${ }_{(\mathrm{pCi} / \mathrm{K})}$ \\
\hline $6-2-2$ & soil sed & 35 & $2.36 \pm 0.05$ & & $10.9 \pm 0.4$ \\
\hline GC-6-2-2 & soil sed & 35 & $2.94 \pm 0.04$ & $>181$ & $12.6 \pm 0.5$ \\
\hline $6-2-3$ & sandy mud & 27 & $1.28 \pm 0.03$ & & $12.1 \pm 0.3$ \\
\hline $6-2-4$ & soft sed & 45 & $2.81 \pm 0.06$ & & $12.9 \pm 0.5$ \\
\hline GC-6-2-4 & soft sed & 45 & $3.44 \pm 0.07$ & $>218$ & $13.2 \pm 0.6$ \\
\hline $6-2-5$ & $\begin{array}{l}\text { hard clay } \\
\text { mud }\end{array}$ & 20 & $2.20 \pm 0.03$ & & $15.4 \pm 0.3$ \\
\hline $6-3-1$ & sandy mud & 30 & $2.39 \pm 0.03$ & & $11.8 \pm 0.2$ \\
\hline C-6-3-1 & sandy mud & 22 & $2.48 \pm 0.04$ & 315 & $13.8 \pm 0.3$ \\
\hline $6-3-2$ & soft sed & 39 & $3.06 \pm 0.06$ & & $13.3 \pm 0.5$ \\
\hline GC-6-3-2 & soft sed & 39 & $3.78 \pm 0.07$ & $>471$ & $14.8 \pm 0.5$ \\
\hline C-6-3-3 & soft sed & 30 & $3.11 \pm 0.07$ & 542 & $17.1 \pm 0.7$ \\
\hline $6-4-1$ & sand gravel & 20 & $0.89 \pm 0.02$ & & $7.3 \pm 0.2$ \\
\hline $6-4-2$ & sand gravel & 20 & $1.38 \pm 0.03$ & & $6.9 \pm 0.2$ \\
\hline $6-4-3$ & sand gravel & & no sample & & \\
\hline $6-4-4$ & soft sed & 25 & $2.61 \pm 0.03$ & & $13.7 \pm 0.3$ \\
\hline$C-6-4-4$ & soft sed & 26 & $2.85 \pm 0.07$ & 532 & $15.1 \pm 0.1$ \\
\hline $6-4-5$ & soft sed & 25 & $2.89 \pm 0.05$ & & $14.1 \pm 0.4$ \\
\hline $6-4-6$ & soft sed & 50 & $2.92 \pm 0.06$ & & $13.9 \pm 0.5$ \\
\hline GC-6-4-M & soft sed & 50 & $3.37 \pm 0.08$ & $>403$ & $12.6 \pm 0.5$ \\
\hline $6-4-7$ & soft sed & 50 & $3.16 \pm 0.05$ & & $14.5 \pm 0.4$ \\
\hline $6-4-8$ & soft sed & 30 & $2.87 \pm 0.08$ & & $13.3 \pm 0.6$ \\
\hline $6-4-9$ & soil sed & 25 & $2.21 \pm 0.03$ & & $9.1 \pm 0.3$ \\
\hline GC-6-4-9 & soil sed & 25 & $3.42 \pm 0.07$ & $>102$ & $14.5 \pm 0.5$ \\
\hline $7-1-1$ & soft sed & 35 & $2.34 \pm 0.04$ & & $12.9 \pm 0.4$ \\
\hline C-7-1-1 & soft sed & 30 & $2.64 \pm 0.05$ & 308 & $11.6 \pm 0.9$ \\
\hline $7-1-2$ & sand gravel & 5 & no sample & & \\
\hline $7-1-3$ & sandy mud & 21 & $0.58 \pm 0.01$ & & $11.9 \pm 0.2$ \\
\hline $7-1-4$ & soft sed & 50 & $3.01 \pm 0.05$ & & $12.8 \pm 0.4$ \\
\hline $7.1-5$ & soft sed & 50 & $2.85 \pm 0.06$ & & $14.2 \pm 0.5$ \\
\hline GC-7-1-5 & soft sed & 50 & $3.97 \pm 0.10$ & $>311$ & $15.2 \pm 0.7$ \\
\hline GC-7-1-M & soft sed & 52 & $3.97 \pm 0.12$ & & $19.5 \pm 2.0$ \\
\hline $7-1.6$ & sand gravel & & no sample & & \\
\hline $7-2-1$ & soft sed & 22 & $2.01 \pm 0.05$ & & $11.0 \pm 0.5$ \\
\hline $7-2-2$ & soft sed & 55 & $2.98 \pm 0.06$ & & $11.8 \pm 0.5$ \\
\hline GC-7-2-2 & soft sed & 57 & $4.30 \pm 0.09$ & $>439$ & $14.9 \pm 0.8$ \\
\hline $7-2-3$ & sand gravel & 20 & no sample & & \\
\hline $7-2-4$ & sand gravel & 16 & $0.91 \pm 0.03$ & & $9.7 \pm 0.3$ \\
\hline $7-2.5$ & soft sed & 36 & $2.55 \pm 0.06$ & & $12.1 \pm 0.5$ \\
\hline GC-7-2-5 & soft sed & 40 & $3.98 \pm 0.10$ & $>508$ & $16.3 \pm 0.8$ \\
\hline $7-2-6$ & soft sed & 52 & $3.05 \pm 0.06$ & & $14.0 \pm 0.5$ \\
\hline $7 .-2-7$ & clay mud & 53 & $2.86 \pm 0.05$ & & $14.5 \pm 0.4$ \\
\hline GC-7-2-7 & clay mud & 53 & $4.02 \pm 0.11$ & $>205$ & $16.5 \pm 0.7$ \\
\hline
\end{tabular}


Radionuclide concentrations (continued)

\begin{tabular}{|c|c|c|c|c|c|}
\hline $\begin{array}{c}\text { Sample } \\
\text { identification }\end{array}$ & $\begin{array}{c}\text { Sample } \\
\text { type }\end{array}$ & $\begin{array}{l}\text { Depth } \\
\text { (ft) }\end{array}$ & $\begin{array}{c}{ }^{137} \mathrm{Cs} \\
(\mathrm{pCi} / \mathrm{g})\end{array}$ & $\begin{array}{c}{ }^{137} \mathrm{Cs} \\
\left(\mathrm{pCi} / \mathrm{cm}^{2}\right)\end{array}$ & $(\mathrm{pCi} / \mathrm{g})$ \\
\hline ROCKWD LAND & soil sed & 15 & $1.25 \pm 0.04$ & 84 & $11.6 \pm 0 . r$ \\
\hline NEW HOPE & sand gravel & 12 & $0.18 \pm 0.02$ & 4 & $2.6 \pm 0.2$ \\
\hline $7-3-1$ & soft sed & 35 & $2.23 \pm 0.04$ & & $12.9 \pm 0.4$ \\
\hline 7.3 .2 & clay mud & 25 & $2.68 \pm 0.02$ & & $13.4 \pm 0.2$ \\
\hline $7.3-3$ & soft sed & 50 & $3.14 \pm 0.06$ & & $13.3 \pm 0.5$ \\
\hline GC-7.3.4 & sofi sed & 50 & $4.08 \pm 0.04$ & $>634$ & $15.6 \pm 0.4$ \\
\hline $7.3-4$ & soft sed & 50 & $2.15 \pm 0.03$ & & $11.0 \pm 0.3$ \\
\hline 7.3 .5 & soft sed & 23 & $4.46 \pm 0.05$ & & $15.3 \pm 0.3$ \\
\hline C.7.3.5 & soft sed & 23 & $3.36 \pm 0.05$ & 440 & $16.7 \pm 0.7$ \\
\hline $7-3-6$ & soil sed & 17 & no sample & & \\
\hline $7 A-1-1$ & sandy mud & 12 & $0.51 \pm 0.03$ & & $7.6 \pm 0.4$ \\
\hline $7 A-1-2$ & soft sed & 16 & $0.60 \pm 0.02$ & & $6.7 \pm 0.4$ \\
\hline $7 A-1-3$ & clay mud & 15 & $0.57 \pm 0.02$ & & $8.9 \pm 0.2$ \\
\hline $7 A-1-4$ & clay mud & 26 & $0.71 \pm 0.02$ & & $11.0 \pm 0.3$ \\
\hline $7 A-1-5$ & soft sed & & $1.17 \pm 0.03$ & & $11.5 \pm 0.3$ \\
\hline $7 A \cdot 1-6$ & soft sed & 40 & $1.04 \pm 0.03$ & & $12.2 \pm 0.3$ \\
\hline $7 A-1.7$ & sandy mud & 39 & $0.62 \pm 0.02$ & & $4.7 \pm 0.2$ \\
\hline $7 A-1-8$ & soft sed & 25 & $1.29 \pm 0.03$ & & $12.9 \pm 0.4$ \\
\hline $7 A-1-9$ & clay mud & 32 & $1.36 \pm 0.03$ & & $12.4 \pm 0.3$ \\
\hline $7 A-1 \cdot 10$ & soft sed & 45 & $2.14 \pm 0.04$ & & $13.0 \pm 0.4$ \\
\hline GC-7A-1-10 & soft sed & 33 & $2.48 \pm 0.05$ & 124 & $13.5 \pm 0.5$ \\
\hline $7 A-1-11$ & sandy mud & 30 & $0.86 \pm 0.02$ & & $10.5 \pm 0.3$ \\
\hline $7 A-2-1$ & gravel & & no sample & & \\
\hline $7 A \cdot 2-2$ & clay mud & 20 & $2.06 \pm 0.02$ & & $12.5 \pm 0.2$ \\
\hline$G C-7 A-2-2$ & soft mud & 25 & $2.52 \pm 0.04$ & $>153$ & $14.3 \pm 0.4$ \\
\hline $8-1-1$ & soft sed & 30 & $2.05 \pm 0.03$ & & $15.6 \pm 0.3$ \\
\hline $8-1-2$ & soft sed & 35 & $2.36 \pm 0.05$ & & $18.4 \pm 0.5$ \\
\hline GC.8.1.2 & clay mud & 35 & $2.05 \pm 0.06$ & 158 & $16.5 \pm 0.7$ \\
\hline $8-1-3$ & soil gravel & 33 & no sample & & \\
\hline $8-1-4$ & soft sed & 55 & $2.73 \pm 0.05$ & & $14.7 \pm 0.5$ \\
\hline GC- $8-1-4$ & soft sed & 55 & $3.44 \pm 0.07$ & $>629$ & $14.6 \pm 0.7$ \\
\hline $8-1.5$ & clay mud & 32 & $3.95 \pm 0.05$ & & $12.5 \pm 0.4$ \\
\hline GC-8-1-5 & clay mud & 32 & $3.20 \pm 0.07$ & 163 & $15.0 \pm 0.7$ \\
\hline $8-1-6$ & soft mud & 55 & $3.63 \pm 0.07$ & & $15.9 \pm 0.6$ \\
\hline $8-1-7$ & soft mud & 57 & $3.38 \pm 0.07$ & & $15.1 \pm 0.6$ \\
\hline GC. 8.1 .7 & soft sed & 55 & $3.79 \pm 0.10$ & 180 & $13.6 \pm 1.0$ \\
\hline $8 \cdot 2-1$ & soil gravel & 45 & no sample & & \\
\hline $8-2-2$ & soft sed & 60 & $2.90 \pm 0.06$ & & $13.4 \pm 0.5$ \\
\hline $8-2 \cdot 3$ & soft sed & 65 & $2.57 \pm 0.05$ & & $12.5 \pm 0.5$ \\
\hline GC-8-2-3 & solt sed & 60 & $3.84 \pm 1.00$ & 342 & $14.7 \pm 1.1$ \\
\hline $8-2-4$ & sandy mud & 33 & $1.64 \pm 0.02$ & & $13.7 \pm 0.2$ \\
\hline GC-8-2-4 & sandy mud & 30 & $1.700 \pm 0.04$ & $i 2$ & $16.4 \pm 0.5$ \\
\hline
\end{tabular}


Radionuclide concentrations (continued)

\begin{tabular}{|c|c|c|c|c|c|}
\hline $\begin{array}{c}\text { Sample } \\
\text { identification }\end{array}$ & $\begin{array}{c}\text { Sample } \\
\text { type }\end{array}$ & $\begin{array}{l}\text { Depth } \\
\text { (fi) }\end{array}$ & $\begin{array}{c}{ }^{137} \mathrm{Cs} \\
(\mathrm{pCi} / \mathrm{g})\end{array}$ & $\begin{array}{c}{ }^{137} \mathrm{Cs} \\
\left(\mathrm{pCi} / \mathrm{cm}^{2}\right)\end{array}$ & $\begin{array}{c}{ }^{6 K} \\
(\mathrm{pCi} / \mathrm{g})\end{array}$ \\
\hline $8-3-1$ & soft sed & & $2.84 \pm 0.06$ & & $13.6 \pm 0.5$ \\
\hline GC-8-3-1 & soft sed & & $4.24 \pm 0.05$ & $>271$ & $15.9 \pm 0.5$ \\
\hline 8.3 .2 & sand gravel & & no sample & & \\
\hline $8-3-3$ & soft sed & 20 & $2.02 \pm 0.03$ & & $11.4 \pm 0.3$ \\
\hline GC-8-3-3 & soil sed & 20 & $1.71 \pm 0.02$ & 134 & $10.9 \pm 0.2$ \\
\hline $9-1.1$ & soft sed & 20 & $4.29 \pm 0.05$ & & $15.7 \pm 0.4$ \\
\hline GC-9-1-1 & sandy mud & 20 & $2.52 \pm 0.06$ & 266 & $14.5 \pm 0.6$ \\
\hline $9-1-2$ & soft sed & 50 & no sample & & \\
\hline GC-9-1-2 & soft sed & 50 & $2.55 \pm 0.05$ & $>505$ & $11.7 \pm 0.4$ \\
\hline $9-1-3$ & sandy soil & 4 & no sample & & \\
\hline $9-1-3 A$ & sandy soil & 10 & $0.48 \pm 0.01$ & & $5.4 \pm 0.2$ \\
\hline GC-9-1-3A & sandy soil & 10 & $0.64 \pm 0.02$ & 6 & $6.8 \pm 0.3$ \\
\hline $9-1-4$ & soil gravel & 15 & $0.31 \pm 0.02$ & & $11.3 \pm 0.3$ \\
\hline $9-1-5$ & soil gravel & & $1.17 \pm 0.03$ & & $10.2 \pm 0.3$ \\
\hline $9-2-1$ & soil gravel & 15 & no sample & & \\
\hline $9.2-2$ & soil gravel & 18 & no sample & & \\
\hline $9-2-3$ & soft sed & 30 & $2.17 \pm 0.02$ & & $12.8 \pm 0.2$ \\
\hline $9-2.4$ & soft sed & 40 & $1.58 \pm 0.02$ & & $9.4 \pm 0.3$ \\
\hline GC-9-2-4 & soil sand & 20 & $0.33 \pm 0.03$ & 1 & $6.4 \pm 0.4$ \\
\hline $9-2-5$ & soft sed & 35 & $2.46 \pm 0.05$ & & $12.3 \pm 0.5$ \\
\hline $9-2-6$ & soft sed & 30 & $3.04 \pm 0.05$ & & $11.5 \pm 0.4$ \\
\hline GC-9-2-6 & soft sed & 30 & $2.00 \pm 0.07$ & $>446$ & $14.4 \pm 0.7$ \\
\hline $9-2.7$ & soft sed & 45 & $1.17 \pm 0.05$ & & $11.0 \pm 0.4$ \\
\hline GC-9-2-7 & soft sed & 25 & $2.75 \pm 0.07$ & 289 & $13.9 \pm 0.7$ \\
\hline $9.2-8$ & soft sed & 40 & $3.16 \pm 0.01$ & & $15.0 \pm 0.6$ \\
\hline GC- 9.2 .8 & soft sed & 30 & $3.31 \pm 0.10$ & 248 & $15.2 \pm 0.9$ \\
\hline $9-2-9$ & soft sed & 48 & $2.59 \pm 0.02$ & & $14.9 \pm 0.1$ \\
\hline $9-2-10$ & sandy mud & 45 & $0.72 \pm 0.01$ & & $12.2 \pm 0.2$ \\
\hline $9-2-11$ & sandy mud & 65 & $1.17 \pm 0.05$ & & $11.7 \pm 0.4$ \\
\hline GC-9-2-11 & sandy mud & 25 & $0.18 \pm 0.0 \mathrm{i}$ & 5 & $9.2 \pm 0.2$ \\
\hline $9-3-1$ & clay sed & 25 & $1.45 \pm 0.03$ & & $9.9 \pm 0.3$ \\
\hline 9.3 .2 & sand gravel & & no sample & & \\
\hline 9.3 .3 & clay sed & 48 & $6.00 \pm 0.05$ & & $12.6 \pm 0.3$ \\
\hline $9.3-4$ & soft sed & 69 & $2.65 \pm 0.04$ & & $14.5 \pm 0.3$ \\
\hline GC-9.3-4 & soft sed & 63 & $2.79 \pm 0.05$ & 341 & $10.7 \pm 0.3$ \\
\hline $9.3-5$ & soft sed & 30 & $4.18 \pm 0.05$ & & $16.1 \pm 0.4$ \\
\hline $9-3-6$ & soft sed & 39 & $2.65 \pm 0.06$ & & $14.0 \pm 0.5$ \\
\hline 9.3 .7 & clay sed & 36 & $2.75 \pm 0.04$ & & $12.9 \pm 0.4$ \\
\hline GC-9-3-7 & soft sed & 36 & $1.89 \pm 0.06$ & 339 & $12.1 \pm 0.6$ \\
\hline $9-3.8$ & soil gravel & 30 & $0.19 \pm 0.02$ & & $6.3 \pm 0.2$ \\
\hline $9-3-9$ & soft sed & 36 & $1.92 \pm 0.05$ & & $10.8 \pm 0.4$ \\
\hline $9-4-1$ & clay sed & 18 & $0.59 \pm 0.02$ & & $5.1 \pm 0.2$ \\
\hline $9-4-2$ & sandy mud & 20 & $\overline{0} .6 \overline{2} \pm \overline{0} . \overline{0} \mathrm{I}$ & & $4.5 \pm 0 . \hat{i}$ \\
\hline
\end{tabular}


Radionuclide concentrations (continued)

\begin{tabular}{|c|c|c|c|c|c|}
\hline $\begin{array}{c}\text { Sample } \\
\text { identification }\end{array}$ & $\begin{array}{c}\text { Sample } \\
\text { type }\end{array}$ & $\begin{array}{c}\text { Depth } \\
\text { (fi) }\end{array}$ & $\begin{array}{l}{ }^{137} \mathrm{Cs} \\
(\mathrm{pCi} / \mathrm{g})\end{array}$ & $\begin{array}{c}{ }^{137} \mathrm{Cs} \\
\left(\mathrm{pCi} / \mathrm{cm}^{2}\right)\end{array}$ & $\begin{array}{c}{ }^{40} \mathrm{~K} \\
(\mathrm{pCi} / \mathrm{g})\end{array}$ \\
\hline $9-4-3$ & soft sed & 48 & $2.46 \pm 0.06$ & & $13.9 \pm 0.5$ \\
\hline GC-9-4-3 & soft sed & 42 & $2.51 \pm 0.10$ & 565 & $12.6 \pm 1.1$ \\
\hline $9-4-4$ & sandy mud & 42 & $2.04 \pm 0.02$ & & $11.3 \pm 0.2$ \\
\hline $9-4-5$ & soft sed & 75 & $2.51 \pm 0.06$ & & $13.0 \pm 0.6$ \\
\hline GC-9-4-5 & soft sed & 70 & $2.34 \pm 0.04$ & 122 & $13.2 \pm 0.7$ \\
\hline $10-1-1$ & sandy mud & 27 & $0.69 \pm 0.03$ & & $5.9 \pm 0.3$ \\
\hline GC-10-1-2 & soft sed & 30 & $1.12 \pm 0.04$ & 108 & $10.8 \pm 0.5$ \\
\hline $10-1-3$ & sandy mud & 12 & $0.17 \pm 0.01$ & & $2.6 \pm 0.1$ \\
\hline $10-1-4$ & clay mud & 15 & $0.40 \pm 0.02$ & & $6.9 \pm 0.3$ \\
\hline $10-2-1$ & soft sed & 27 & $0.80 \pm 0.02$ & & $10.5 \pm 0.3$ \\
\hline $10-2-2$ & soft sed & 22 & $0.73 \pm 0.04$ & & $7.3 \pm 0.4$ \\
\hline GC-10-2-A & soft sed & 30 & $0.82 \pm 0.05$ & 21 & $10.2 \pm 0.5$ \\
\hline $10-3-1$ & sand gravel & 17 & $0.05 \pm 0.01$ & & $0.9 \pm 0.1$ \\
\hline $10-3-2$ & sandy mud & 24 & $0.64 \pm 0.03$ & & $7.7 \pm 0.3$ \\
\hline GC-10-3-2 & sandy mud & 24 & $0.74 \pm 0.06$ & 9 & $8.3 \pm 0.7$ \\
\hline $10-3-3$ & soft sed & 24 & $0.59 \pm 0.03$ & & $6.3 \pm 0.3$ \\
\hline $10-3-4$ & soft sed & 24 & $0.65 \pm 0.01$ & & $7.0 \pm 0.3$ \\
\hline $10-4-1$ & sandy mud & 15 & $0.16 \pm 0.01$ & & $3.1 \pm 0.1$ \\
\hline $10-4-2$ & sandy mud & 14 & $0.16 \pm 0.02$ & & $3.0 \pm 0.2$ \\
\hline $10-4-3$ & soil sed & 10 & $0.32 \pm 0.02$ & & $6.6 \pm 0.3$ \\
\hline $10-4-4$ & soil sed & 9 & $0.28 \pm 0.02$ & & $5.9 \pm 0.3$ \\
\hline $10-4-5$ & soil sed & 15 & $0.27 \pm 0.02$ & & $4.6 \pm 0.3$ \\
\hline $10-4-6$ & sandy mud & 15 & $0.18+0.02$ & & $2.6 \pm 0.2$ \\
\hline $10-5-1$ & soft sed & 33 & $0.69 \pm 0.01$ & & $5.8 \pm 0.1$ \\
\hline $10-5-2$ & sand gravel & 33 & & & \\
\hline $10-5-3$ & soft sed & 36 & $1.44 \pm 0.04$ & & $1.0 \pm 0.4$ \\
\hline GC-10.5-3 & soft sed & 36 & $1.01 \pm 0.05$ & 22 & $10.8 \pm 0.6$ \\
\hline $11-1-1$ & sand & 30 & $0.43 \pm 0.01$ & & $3.6 \pm 0.1$ \\
\hline $11-1-2$ & soft sed & 45 & $2.89 \pm 0.04$ & & $12.7 \pm 0.3$ \\
\hline $11-1-3$ & soft sed & 45 & $2.42 \pm 0.02$ & & $12.7 \pm 0.2$ \\
\hline GC-11-1-3 & sofi sed & 30 & $2.61 \pm 0.06$ & 250 & $12.8 \pm 0.5$ \\
\hline $11-1-4$ & soft sed & 75 & $2.76 \pm 0.04$ & & $16.0 \pm 0.4$ \\
\hline $11-1.5$ & sand gravel & 15 & $0.45 \pm 0.02$ & & $5.1 \pm 0.2$ \\
\hline $11-1-6$ & soft sed & 40 & $2.42 \pm 0.02$ & & $11.4 \pm 0.2$ \\
\hline $11-1-7$ & soft sed & 40 & $2.78 \pm 0.01$ & & $12.1 \pm 0.3$ \\
\hline $11-1-8$ & soft sed & 63 & $1.93 \pm 0.03$ & & $11.1 \pm 0.4$ \\
\hline $11-1-9$ & soft sed & 55 & $2.45 \pm 0.05$ & & $12.8 \pm 0.5$ \\
\hline GC-11-1-9 & soft sed & 55 & $2.44 \pm 0.06$ & 289 & $12.2 \pm 0.5$ \\
\hline $11-1-10$ & soft sed & & $2.42 \pm 0.05$ & & $11.0 \pm 0.5$ \\
\hline $11-1-11$ & soft sed & 45 & $1.83 \pm 0.05$ & & $8.9 \pm 0.4$ \\
\hline $11-2-1$ & soft sed & 75 & $2.71 \pm 0.01$ & & $15.0 \pm 0.4$ \\
\hline GC-11-2-1 & soft sed & 70 & $2.38 \pm 0.08$ & 397 & $11.7 \pm 0.7$ \\
\hline $11-2-2$ & sandy mud & 33 & i.î́ $\pm \hat{0.00 i}$ & & $13.0 \pm 0.2$ \\
\hline
\end{tabular}


Radionuclide concentrations (continued)

\begin{tabular}{|c|c|c|c|c|c|}
\hline $\begin{array}{c}\text { Sample } \\
\text { identification }\end{array}$ & $\begin{array}{c}\text { Sample } \\
\text { type }\end{array}$ & $\begin{array}{l}\text { Depth } \\
\text { (fi) }\end{array}$ & $\begin{array}{c}{ }^{137} \mathrm{Cs} \\
(\mathrm{pCi} / \mathrm{g})\end{array}$ & $\begin{array}{c}{ }^{137} \mathrm{Cs} \\
\left(\mathrm{pCi} / \mathrm{cm}^{2}\right)\end{array}$ & $\begin{array}{c}{ }^{40} \mathrm{~K} \\
(\mathrm{pCi} / \mathrm{g})\end{array}$ \\
\hline $11-2-3$ & sand gravel & 45 & $0.67 \pm 0.01$ & & $11.9 \pm 0.1$ \\
\hline $11-2-4$ & sand gravel & 18 & $0.16 \pm 0.01$ & & $6.1 \pm 0.2$ \\
\hline $11-2-5$ & soft sed & 33 & $1.96 \pm 0.04$ & & $8.9 \pm 0.3$ \\
\hline GC-11-2-5 & soft sed & 35 & $2.32 \pm 0.19$ & 321 & $15.7 \pm 2.3$ \\
\hline $11-2-5 B$ & soft sed & 30 & $1.69 \pm 0.02$ & & $7.1 \pm 0.1$ \\
\hline
\end{tabular}

'Sample types: soft sed = recently deposited soft mud; clay mud = cohesive clayey mud; sandy mud $=$ sandy mud or fine sands; sand $=$ sand and gravel; soil gravel = submerged soil and eroded bank materials.

"No inventory made: core only $24 \mathrm{~cm}$ long. 
ORNL/ER-7

\section{DISTRIBUTION}

1. S. M. Adams

2. L. W. Barnthouse

3. L. D. Bates

4. B. G. Blaylock

5. K. L. Brady

6. C. C. Brandt

7. W. R. Brown

8. G. E. Butterworth

9. T. R. Butz

10. K. W. Cook

11-20. R. B. Cook

21-30. K. C. Dearstone

31. M. F. P. DeLozier

32. E. L. Etnier

33-42. C. J. Ford

43. M. L. Frank

44. C. E. Frye

45. C. W. Gehrs

46. M. Gentry

47. J. Grebmeier

48. J. L. Haymore

49. S. G. Hildebrand

50. F. O. Hoffman

51. L. A Hook

52. D. D. Huff

53. S. V. Kaye

54. C. Kimbrough

55-64. B. L. Kimmel

65. M. Koepp

66-75. I. L. Larsen

76. J. M. Loar

77. L. W. Long
78. P..Y. Lu

79. A. P. Malinauskas

80. L. W. McMahon

81. L. E. McNeese

82. M. E. Mitchell

83. C. E. Nix

84-93. C. R. Olsen

94-95. P. T. Owen

96. J. W. Ranney

97. D. E. Reichle

98. G. E. Rymer

99. P. S. Rohwer

100. T. H. Row

101. M. J. Sale

102. C. L. Stair

103. J. E. Stone

104. S. H. Stow

105. G. W. Suter

106. D. W. Swindle

107. C. C. Travis

108-117. R. R. Turner

118. R. I. Van Hook

119. D. R. Watkins

120. W. Van Winkle

121. L. D. Voorhees

122. R. K. White

123. L. F. Willis

124. Central Research Library

125-144. ER Document Management Center, RC

145-164. ESD Library

165. Laboratory Records Dept.

166. J. J. Alberts, University of Georgia Marine Institute, Sapelo Island, GA 31327

167. L. K. Benninger, Department of Geology, University of North Carolina, Chapel Hill, NC 27514

168. R. F. Bopp, Department of Environmental Science, Barnard College, New York, NY 10027

169. M. H. Bothner, U.S. Geological Survey, Woods Hole, MA 02543

170. O. P. Bricker, U.S. Geological Survey, Water Resources MS 431, Reston, VA 22092

171. Ralph Brooks, TVA, 140 Evans Building, Office of Water Resources, Knoxville, TN 37902 
172. G. R. Choppin, Department of Chemistry, Florida State University, Tallahassee, FL 32306

173. T. M. Church, College of Marine Studies, University of Delaware, Newark, DE 19716

174. J. M. Cleveland, U.S. Geological Survey, P.O.Box 25046, Denver Federal Center, Denver, CO 80225

175. R. J. Cornett, Environmental Research Branch, Chalk River Nuclear Laboratories, Chalk River, Ontario KOJ 1JO, CANADA

176. D. Dycus, TVA, 270 Haney Building, Chattanooga, TN 37402

177. J. Dominik, Institut F.-A. Forel, Universite de Jeneid, 1290 Versoix, SWITZERLAND

178. J. Donoghue, Department of Geology, Florida State University, Tallahassee, FL 32306

179. J. Duguid, Battelle Project Management Division, 2030 M St. NW, Washington, DC 20036

180. D. N. Edgington, Great Lake Studies, P.O. Box 413, University of Wisconsin, Milwaukee, Milwaukee, WI 53201

181. P. H. Edmonds, Radian Corporation, 120 S. Jefferson Circle, Oak Ridge, TN 37830

182. E. H. Essington, Los Alamos Scientific Laboratory, University of California, P.O. Box 1663, Los Alamos, NM 87545

183. J. P. Fehring, TVA, 270 Haney Building, Chattanooga, TN 37402

184-188. Mildred Ferre, DOE Oak Ridge Field Office, P.O. Box 2001, Oak Ridge, TN 37831-8541

189. J. F. Franklin, Bloedel Professor of Ecosystem Analysis, College of Forest Resources, University of Washington, Anderson Hall (AR-10), Seattle, WA 98195

190. C. Gist, DOE Oak Ridge Field Office, P.O. Box 2001, Oak Ridge, TN 37831-8541

191. S. Glover, DOE Oak Ridge Field Office, P.O. Box 2001, Oak Ridge, TN 378318541

192. D. S. Gorsline, Department of Geological Sciences, University of Southern California, Los Angeles, CA 90007

193. T. E. Hakonson, Environmental Sciences Group, Los Alamos National Iaboratory, Los Alamos, NM 87545

194. D. H. Hamilton, Office of Health and Environmental Research, ER-75, Office of Energy Research, U.S. Department of Energy, Washington, DC 20545

195. M. Heits, Environmental Measurements Laboratory, 376 Hudson Street, New York, NY 10014

196. R. A. Hites, Department of Chemistry, Indiana University, 400 East 7 th Street, Bloomington, IN 47405

197. G. M. Hornberger, Professor, Department of Environmental Sciences, University of Virginia, Charlottesville, VA 22903

198. J. W. Huckabee, Manager, Ecological Studies Program, Electric Power Research Institute, 3412 Hillview Avenue, P.O. Box 10412, Palo Alto, CA 94303

199. George Y. Jordy, Director, Office of Program Analysis, Office of Energy Research, ER-30, G-226, U.S. Department of Energy, Washington, DC 20545

200. T. Joseph, DOE Oak Ridge Field Office, P.O. Box 2001, Oak Ridge, TN 3783185,41

201. 3. A. Kuehl, Department of Geology, University of South Carolina, Columbia, SC 29208 
202-206. E. Leming, TDEC, DOE Oversite Division, 761 Emery Valley Road, Oak Ridge, TN 37830-7072

207. P. Linsalata, New York University Medical Center, Institute of Environmental Medicine, Long Meadow Road, Tuxedo, NY 10987

208-217. P. D. Lowry, Department of Anesthesiology, Emory University School of Medicine, Atlanta, GA 30322

218. J.-M. Martin, Institut De Biogeochimie Marine, Ecole Nornale Superieure, 1, rue Maurice Arnoux, F92120 Montrouge, FRANCE

219. J. S. Mattice, Electric Power Research Institute, P.O. Box 10412, Palo Alto, CA 94303

220. L. Mayer, Department of Oceanography, University of Maine, Walpole, ME 04573

221. Helen McCammon, Director, Environmental Sciences Division, Office of Health and Environmental Research, ER-74, U.S. Department of Energy, Washington, DC 20585

222-226. Doug McCoy, TDEC, DOE Oversite Division, 761 Emery Valley Road, Oak Ridge, TN 37830-7072

227. A. D. McKinney, TWRA, P.O. Box 40747, Ellington Agricultural Center, Nashville, TN 37204

228. R. I. McLean, Department of Natural Resources, State of Maryland, Tawes State Office Building, Annapolis, MD 21401

229. R. H. Meade, Water Resources Division, U.S. Geological Survey, Denver, CO 80225

230. R. L. Miller, Earth Resources Laboratory, Earth Sciences Research Division, HA10 Bldg. 1100, Stennis Space Center. MS 39529

231-240. C. R. Moriones, Health Physics Research Division, Philippine Atomic Energy Commission, P.O. Box 213 U.P. Diliman, Quezon City, PHILIPPINES

241-244. R. L. Nace, Department of Energy, Office of Environmental Restoration, Office of Eastern Area Programs, EM-423 (GTN), Washington, DC 20585-0002

245. J. V. Nabholz, Health and Environmental Review Division, Environmental Protection Agency, 401 M Street, SW, Washington, DC 20460

246. A. S. Naidu, Institute of Marine Science, University of Alaska, Fairbanks, AK 99701

247. D. M. Nelson, Radiological and Environmental Research Division, Argonne National Laboratory, Argonne, IL 60439

248. M. M. Nichols, Virginia Institute of Marine Science, Gloucester Point, VA 23062

249. C. Nolan, International Laboratory of Marine Radioactivity, IAEA, 2, av Prince Hereditaire Albert, 98000 MONACO

250. V. E. Noshkin, International Laboratory of Marine Radioactivity, IAEA, 2, av Prince Hereditaire Albert, 98000 MONACO

251. J. O. Nriagu, National Water Research Institute, Canada Centre for Inland Waters, Burlington, Ontario L7R 4A6, CANADA

252. R. H. Olsen, Vice President for Research, University of Michigan, Medical Science Building II, \#5605 1301 East Catherine Street, Ann Arbor, MI 48109-0620

253. W. S. Osburn, Jr., Environmental Sciences Division, Office of Health and Environmental Research, ER-74, U.S. Department of Energy, Washington, DC 20585

254. D. G. Page, DOE Oak Ridge Field Office, P.O. Box 2001, Oak Ridge, TN 378318541 
255. R. Paris, Oregon State Health Division, Department of Human Resources, 1400 SW 5th Avenue, Portland, OR 97201

256. F. L. Parker, Vanderbilt University, Nashville, TN 37240

257. R. W. Perkins, Pacific Northwest Laboratories, P.O. Box 999, Richland, WA 99352

258. J. Porter, Director, Environmental Sciences Section, Savannah River Laboratory, Aiken, SC 29801

259. J. Robbins, Great Lakes Environmental Research Laboratory, Ann Arbor, MI 48104

260. E. J. Rykiel, Department of Industrial Engineering, Biosystems Research Division, Texas A\&M University, College Station, TX 77843

261. P. H. Santschi, Department of Oceanography, Texas A\&M University, College Station, TX 77843

262. G. W. Saunders, Jr., Office of Health and Environmental Research, ER-75, Office of Energy Research, U.S. Department of Energy, Washington, DC 20545

263. W. R. Schell, Department of Radiation Health, University of Pittsburgh, Pittsburgh, PA 15261

264. W. Schacher, TWRA, 4600 Appleby Road, Knoxville, TN 37920

265. J. R. Schubel, Marine Sciences Research Center, State University of New York, Stony Brook, NY 11794

266. M. R. Scott, Department of Oceanography, Texas A\&M University, College Station, TX 77843

267. J. Skei, Norwegian Institute for Water Research, P.B. 333 Blindern, 0314 Oslo 3, NORWAY

268-287. R. C. Sleeman, DOE Oak Ridge Field Office, P.O. Box 2001, Oak Ridge, TN 37831-8541

288. J. N. Smith, Department of Fisheries and Oceans, Bedford Institute of Oceanography, Dartmouth, Nova Scotia B2Y 4A2, CANADA

289. P. Supaokit, Office of Atomic Energy for Peace, Thanon Vibhavadi Rangsit, Bangkhen, Bangkok, 10900 THAILAND

290. D. J. P. Swift, Department of Oceanography, Old Dominion University, Norfolk, VA 23508

291. G. Toombs, Oregon State Health Divison, Department of Human Resources, 1400 SW 5th Avenue, Portland, OR 97201

292. K. K Turekian, Department of Geology and Geophysics, Yale University, New Haven, CT 06520

293. H. L. Windom, Skidaway Institute of Oceanography, P.O. Box 13687, Savannah, GA 31406

294. Frank J. Wobber, Environmental Sciences Division, Office of Health and Environmental Research, ER-74, U.S. Department of Energy, Washington, DC 20585

295. R. W. Wood, Director, Office of Health and Environmental Research, Office of Energy Research, Department of Energy, Washington, DC 20545

296. Office of Assistant Manager for Energy Research and Development, Oak Ridge Operations, P.O. Box 2001, U.S. Department of Energy, Oak Ridge, TN 37831-8600

297--298. Office of Scientific and Technical Information, P.O. Box 62, Oak Ridge, TN 37831 

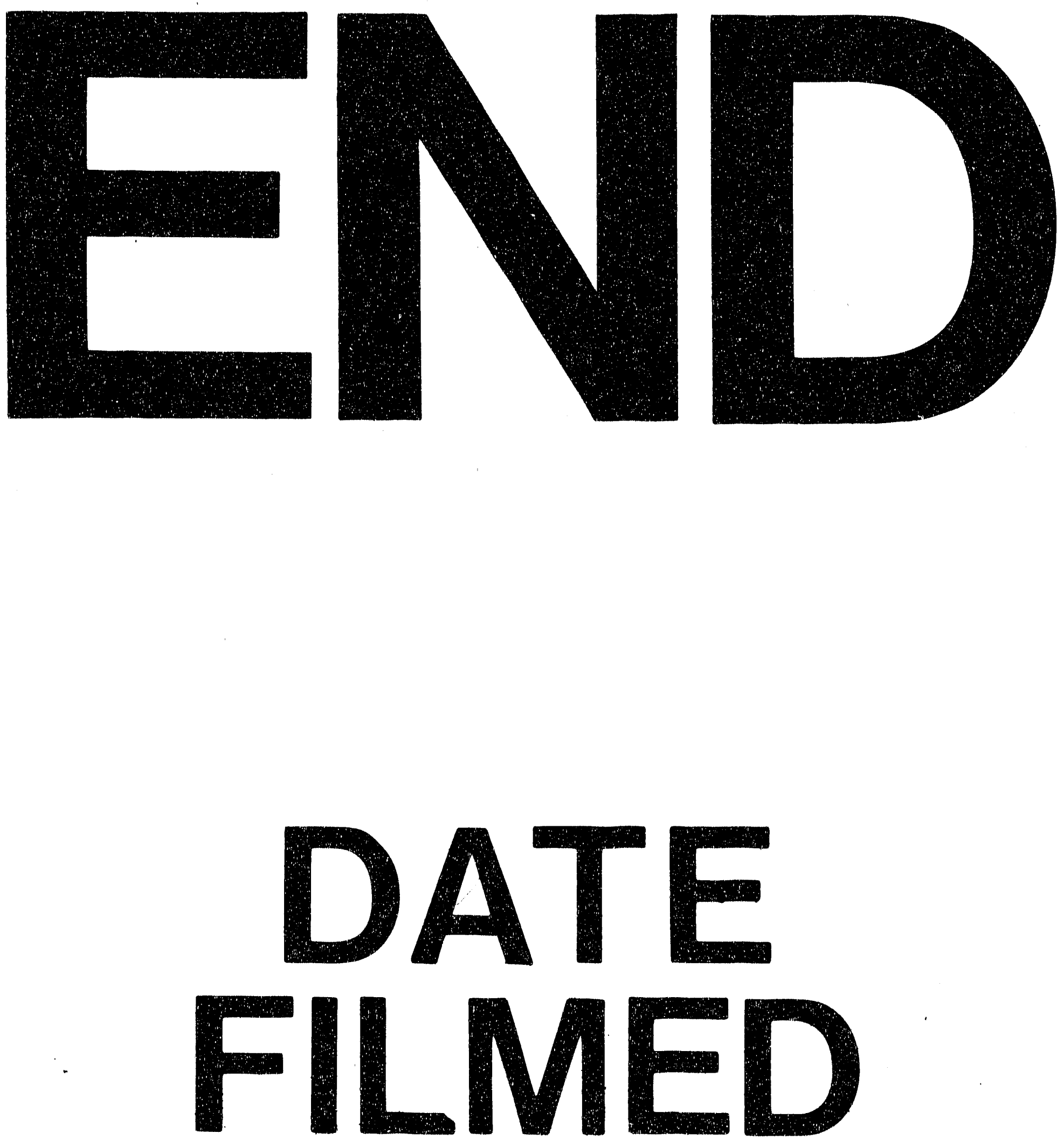

㑒

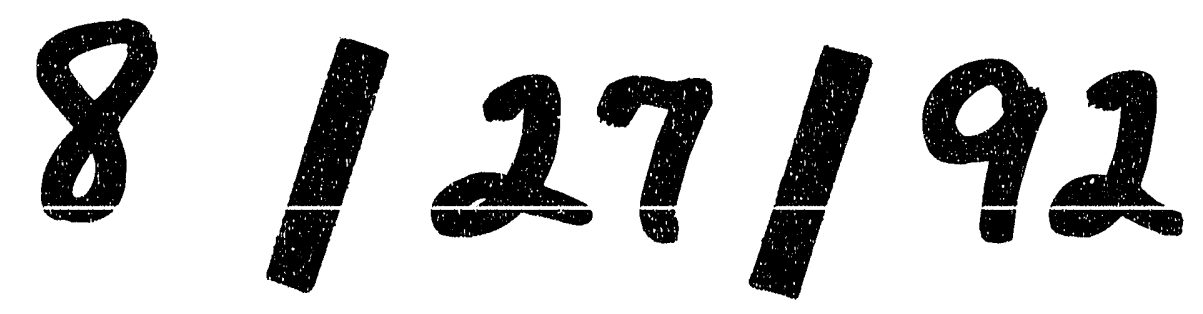


$=$
$\bar{\equiv}$

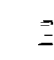

